\title{
Evaluation of Groundwater
} Impacts to Support the National Environmental Policy Act Environmental Assessment for the INL Remote-Handled Low-Level Waste Disposal Project

August 2010

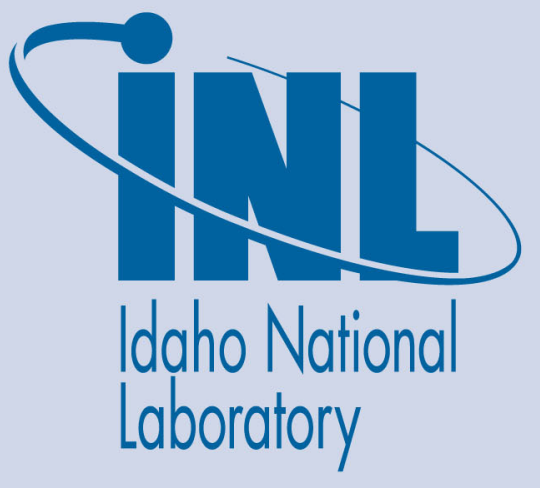

The INL is a U.S. Department of Energy National Laboratory operated by Battelle Energy Alliance 


\section{DISCLAIMER}

This information was prepared as an account of work sponsored by an agency of the U.S. Government. Neither the U.S. Government nor any agency thereof, nor any of their employees, makes any warranty, expressed or implied, or assumes any legal liability or responsibility for the accuracy, completeness, or usefulness, of any information, apparatus, product, or process disclosed, or represents that its use would not infringe privately owned rights. References herein to any specific commercial product, process, or service by trade name, trade mark, manufacturer, or otherwise, does not necessarily constitute or imply its endorsement, recommendation, or favoring by the U.S. Government or any agency thereof. The views and opinions of authors expressed herein do not necessarily state or reflect those of the U.S. Government or any agency thereof. 


\section{Evaluation of Groundwater Impacts to Support the National Environmental Policy Act Environmental Assessment for the INL Remote-Handled Low-Level Waste Disposal Project}

August 2010

Idaho National Laboratory Idaho Falls, Idaho 83415

http://www.inl.gov

Prepared for the

U.S. Department of Energy

Office of Nuclear Energy

Under DOE Idaho Operations Office

Contract DE-AC07-05ID14517 



\begin{abstract}
Groundwater impacts have been analyzed for the proposed remote-handled low-level waste disposal facility. The analysis was prepared to support the National Environmental Protection Agency environmental assessment for the top two ranked sites for the proposed disposal facility. A four-phase screening and analysis approach was documented and applied. Phase I screening was site independent and applied a radionuclide half-life cut-off of 1 year. Phase II screening applied the National Council on Radiation Protection analysis approach and was site independent. Phase III screening used a simplified transport model and site-specific geologic and hydrologic parameters. Phase III neglected the infiltration-reducing engineered cover, the sorption influence of the vault system, dispersion in the vadose zone, vertical dispersion in the aquifer, and the release of radionuclides from specific waste forms. These conservatisms were relaxed in the Phase IV analysis which used a different model with more realistic parameters and assumptions.

Phase I screening eliminated 143 of the 245 radionuclides in the inventory from further consideration because their half-life was less than 1 year. An additional 13 were removed because there was no ingestion dose conversion factor available. Of the 89 radionuclides carried forward from Phase I, 56 radionuclides had Phase II screening doses exceeding $0.4 \mathrm{mrem} /$ year. Phase III and IV screening compared the maximum predicted radionuclide concentration in the aquifer to maximum contaminant limits. Of the 56 radionuclides carried forward from Phase II, six radionuclides were identified in Phase III as having aquifer concentrations exceeding maximum contaminant limits. Phase IV analysis showed that none of the six remaining radionuclides exceeded the maximum contaminant limits for either facility. An evaluation of composite impacts showed one site is preferable over the other based on the potential for commingling of groundwater contamination with other facilities.
\end{abstract}




\section{CONTENTS}

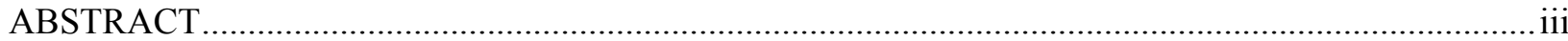

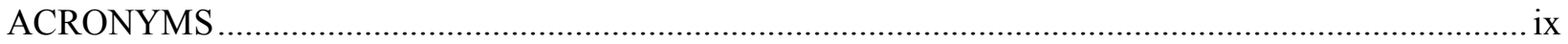

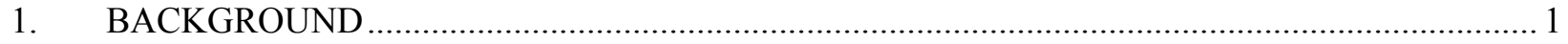

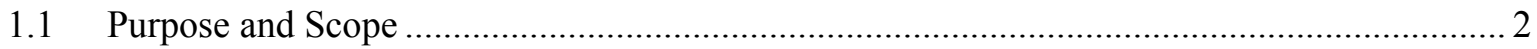

2. EXPOSURE PATHWAYS AND PERFORMANCE MEASURES …....................................... 3

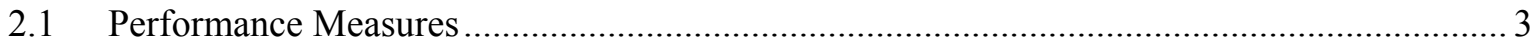

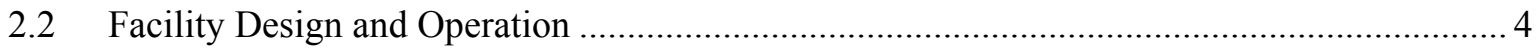

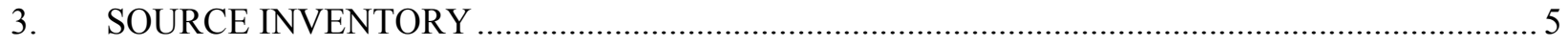

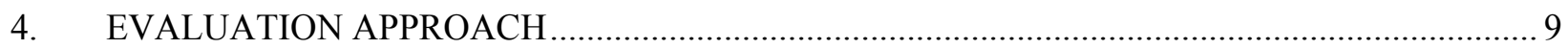

4.1 Phase I: Radionuclide Half-Life Screening ...................................................................... 9

4.2 Phase II: National Council on Radiation Protection Screening ......................................... 9

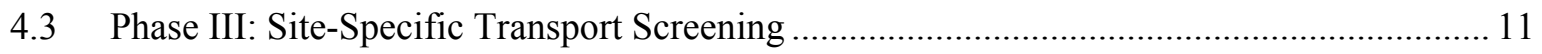

4.3.1 Flow and Transport Processes.......................................................................... 11

4.3.2 Phase III Model Parameterization....................................................................... 14

4.4 Phase IV: Detailed Source Release with Site-Specific Transport ....................................... 23

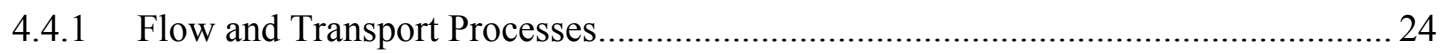

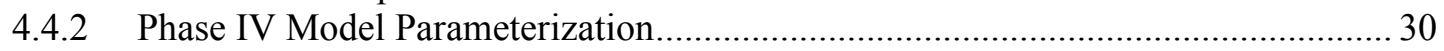

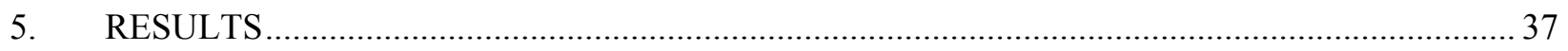

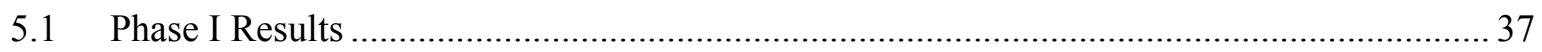

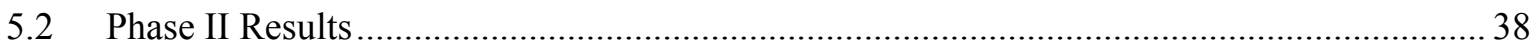

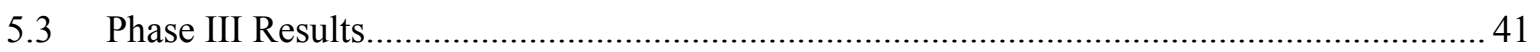

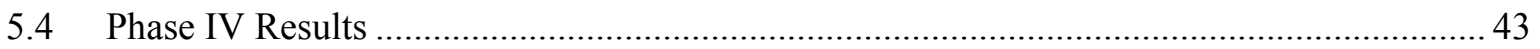

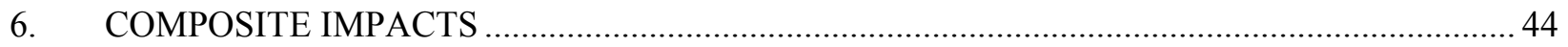

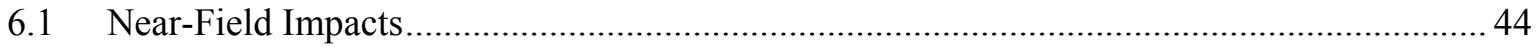

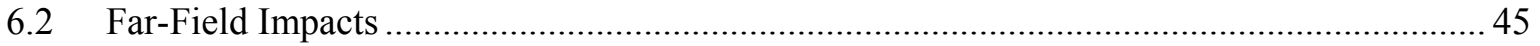

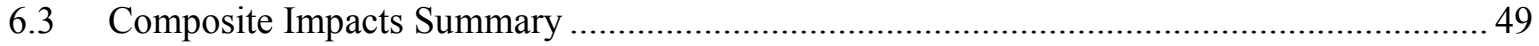




\section{FIGURES}

1. Highest ranked candidate sites for the proposed remote-handled low-level waste disposal facility. 1

2. Simplified conceptual model of the groundwater ingestion pathway........................................ 2

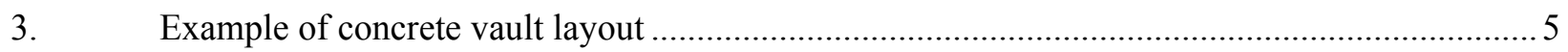

4. Preliminary cover design for the Idaho National Laboratory remote-handled low-level

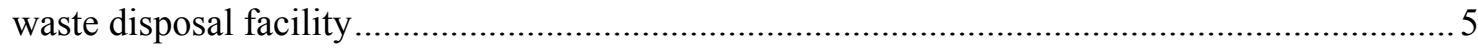

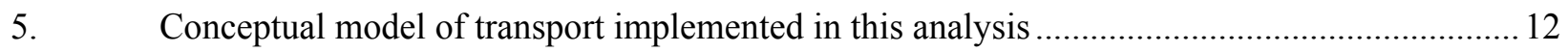

6. Geologic cross-section showing sedimentary interbed elevations and thicknesses near Site 5 southeast of the Advanced Test Reactor Complex ....................................................... 19

7. Location of the geologic cross-section near Site 5 shown in Figure 6 ...................................20

8. North-south geologic cross-section (A-A') at the Idaho Nuclear Technology and

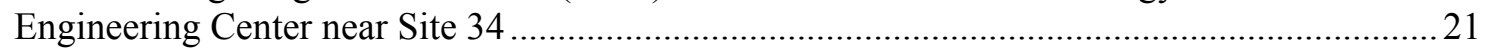

9. Location of the north-south geologic cross-section (A-A') at the Idaho Nuclear Technology and Engineering Center shown in Figure 8

10. The mixing cell conceptual model for water flow (left) and contaminant transport (right).

11. Discretization of the cement-sand-vault system, alluvial base layer, basalt, and sedimentary interbeds used to represent the subsurface at Site 5.

12. Discretization of the cement-sand-vault system, alluvial base layer, basalt, and sedimentary interbeds used to represent the subsurface at Site 34 .

13. Location of the Idaho CERCLA Disposal Facility complex

14. Sum of simulated beta-emitting radionuclide concentrations divided by respective drinking water limits for 2005

15. Sum of simulated beta-emitting radionuclide concentrations divided by respective drinking water limits for 2095 


\section{TABLES}

1. Projected 50-year inventory of remote-handled low-level waste ....................................... 6

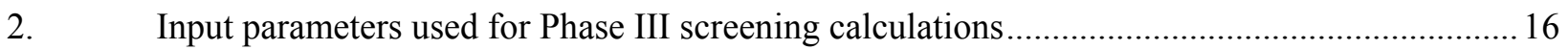

3. Corrosion rates and fractional release rates for buried metals in Idaho National

Laboratory soils

4. Distribution coefficients $(\mathrm{mL} / \mathrm{g})$ for the cement-sand vault environment .............................. 34

5. Distribution coefficients $(\mathrm{mL} / \mathrm{g})$ for gravel, sand, loam (silt), and clay from Sheppard and Thibault (1990), with computed values for Sites 34 and 5, based on soil texture and values used in the Operable Unit 3-14 remedial investigation/baseline risk assessment

6. Distribution coefficients $(\mathrm{mL} / \mathrm{g})$ used in the Phase IV screening analysis ...............................35

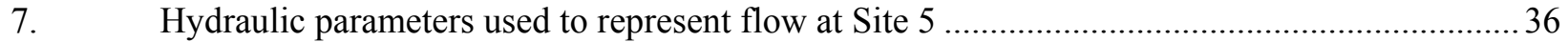

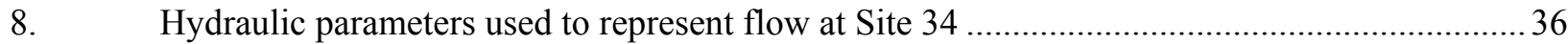

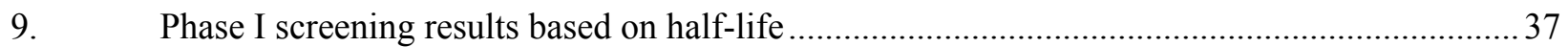

10. Phase II screening results using the National Council on Radiation Protection screening factors

11. Phase III screening results based on site-specific transport................................................... 41

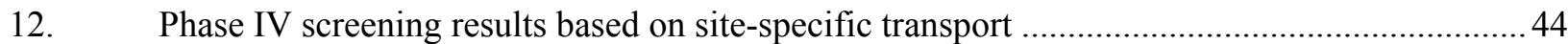




\section{ACRONYMS}

ATR Advanced Test Reactor

CERCLA Comprehensive Environmental Response Compensation and Liability Act

DOE Department of Energy

EDE $\quad$ effective dose equivalent

ICDF INL CERCLA Disposal Facility

INL Idaho National Laboratory

INTEC Idaho Nuclear Technology and Engineering Center

$\mathrm{K}_{\mathrm{d}} \quad$ distribution coefficient

LLW low-level waste

MCL maximum contaminant level

MCM mixing cell model

NCRP National Council on Radiation Protection

RH remote-handled

RWMC Radioactive Waste Management Complex 


\section{Evaluation of Groundwater Impacts to Support the National Environmental Policy Act Environmental Assessment for the INL Remote-Handled Low-Level Waste Disposal Project}

\section{BACKGROUND}

Since 1952, all remote-handled low-level waste (RH-LLW) generated at the Idaho National Laboratory (INL) has been disposed of at the Subsurface Disposal Area of the Radioactive Waste Management Complex (RWMC). In anticipation of closure of RWMC, INL is proposing to establish a new RH-LLW disposal facility. In compliance with the National Environmental Policy Act (42 USC $\$ 4321$ et seq.), an evaluation of the impacts on the human environment must be conducted. In this case, it will require evaluation of the two highest ranked candidate sites (Harvego et al. 2010).

The two highest ranked sites are located (1) southwest of the Advanced Test Reactor (ATR) Complex (Site 5) and (2) southwest of the Idaho Nuclear Technology and Engineering Center (INTEC) (Site 34) (see Figure 1). These sites are similar demographically and climatographically. They are both located near the ephemeral Big Lost River and are roughly equidistant (about $450 \mathrm{ft}$ ) above the underlying Snake River Plain Aquifer. Contaminants released from either of these facilities could be transported downward through the stratigraphic layers comprising the vadose zone and into the aquifer. This assessment estimates groundwater impacts by calculating the dose to a hypothetical receptor that ingests contaminated groundwater.

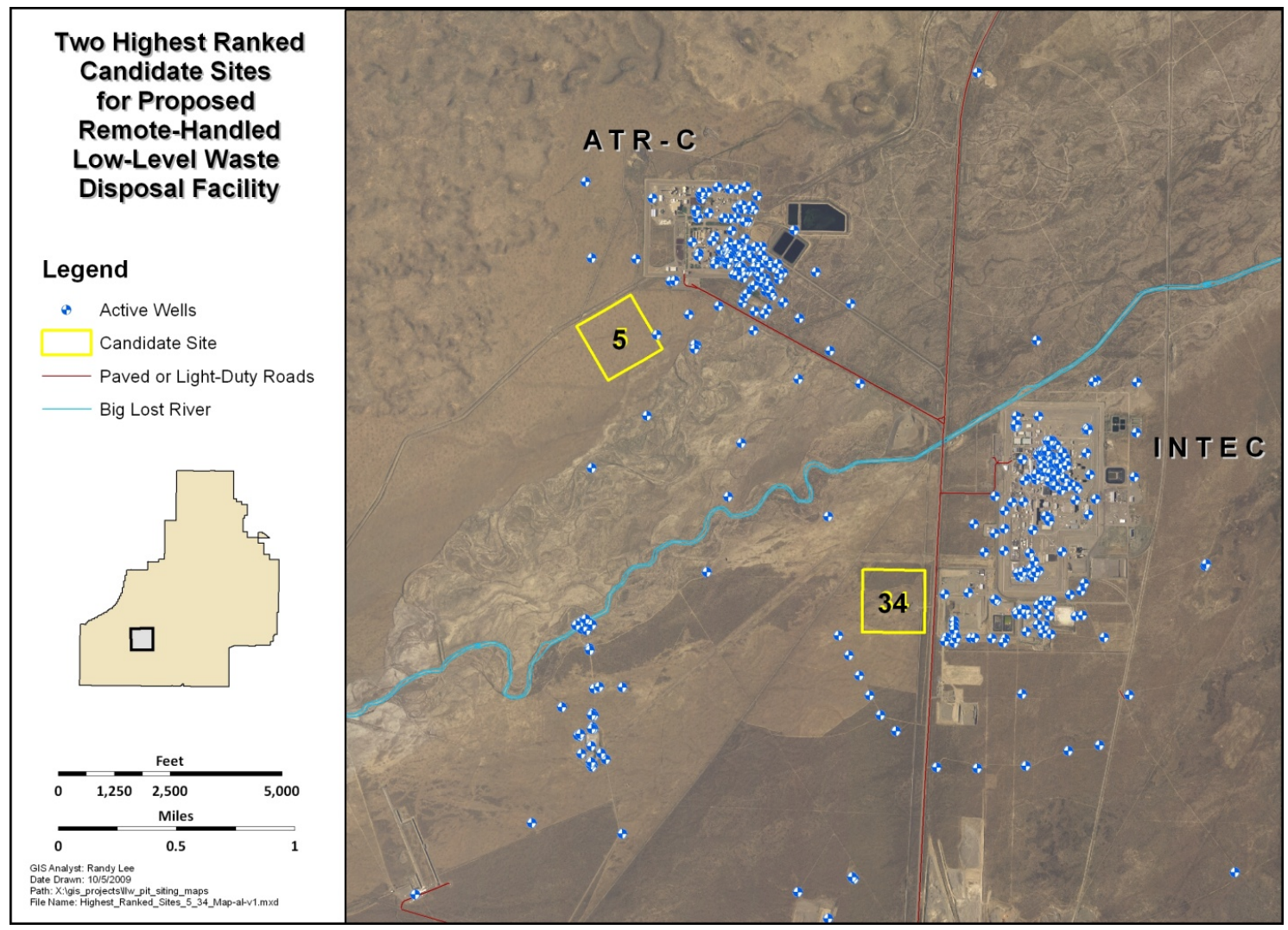

Figure 1. Highest ranked candidate sites for the proposed remote-handled low-level waste disposal facility. 


\subsection{Purpose and Scope}

The purpose of this document is to assess groundwater impacts for the proposed RH-LLW disposal facility at INL. It includes an evaluation of radionuclide transport from the facility to a hypothetical receptor via the groundwater pathway and compares screening level predictions of groundwater concentrations to federal drinking water standards. The evaluation supports the National Environmental Policy Act environmental assessment of the two highest ranked candidate sites for the proposed facility.

The groundwater pathway from the disposal facility to the aquifer is illustrated in Figure 2. Radiologic doses via the groundwater pathway are governed by the release of radionuclides from the waste form to the vadose zone, radioactive decay and hydrodynamic dispersion during transit in the vadose zone en route to the aquifer, and dilution in the aquifer. Residence time in the vadose zone is controlled by the infiltration rate, vadose zone sediment thickness, and sorption. The residence time in the vadose zone allows for decay of the parent radionuclide and ingrowth and decay of progeny. The decay rate also is radionuclide specific and is determined by the half-life of each radionuclide. Sorption serves to retard the rate of downward migration and is dependent on water chemistry and solid surfaces in addition to being radionuclide specific. Dilution in the aquifer is controlled by the Darcy velocity in the aquifer underlying the disposal facility and by hydrodynamic dispersion. The aquifer velocity is spatially variable underlying INL and is site specific.

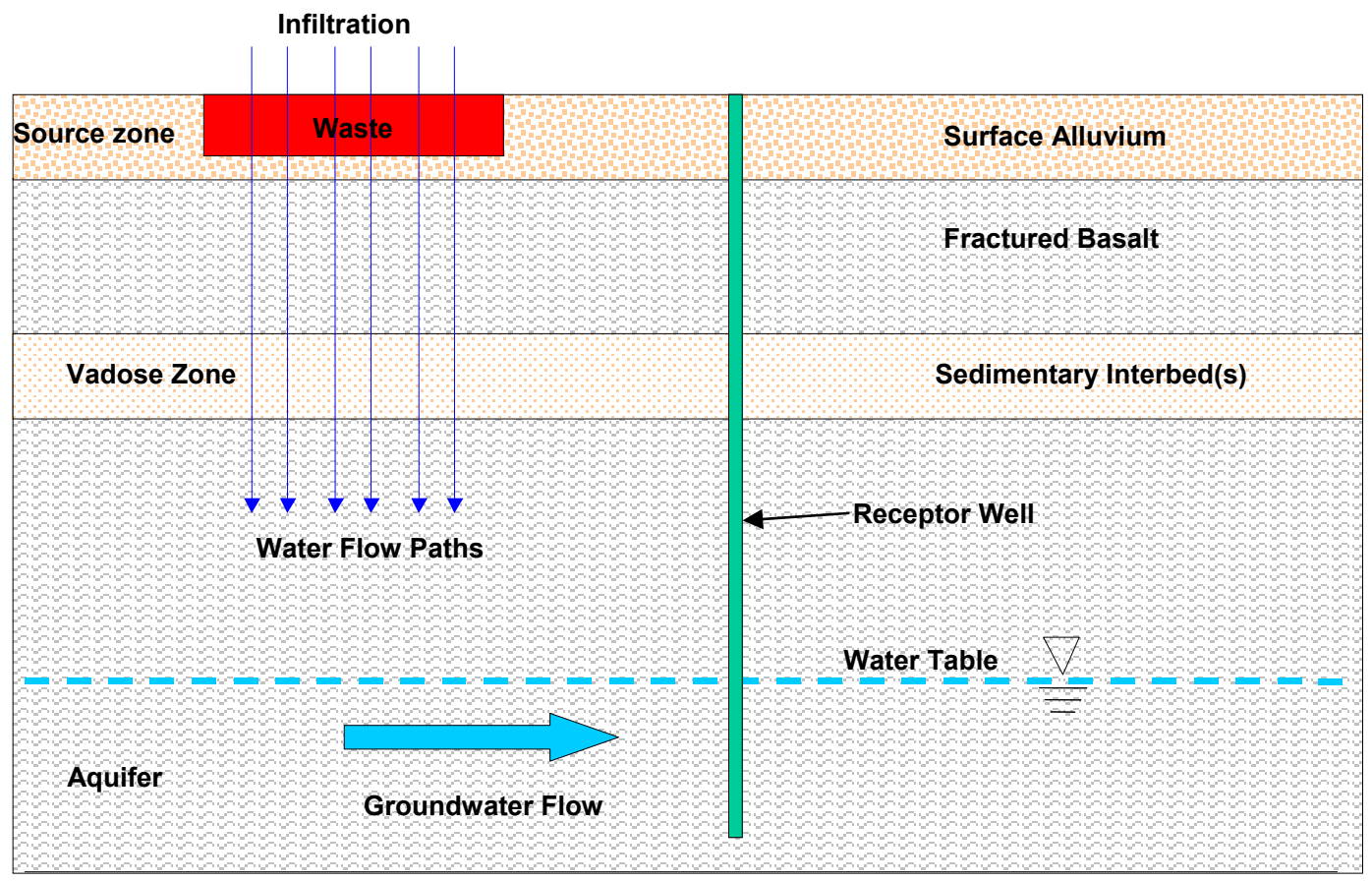

Figure 2. Simplified conceptual model of the groundwater ingestion pathway.

The initial inventory consists of radionuclides with a wide range of sorption characteristics and a wide range of half-lives. Radionuclides with very short half-lives will decay before a significant quantity leaches from the waste or moves through the vadose zone to the aquifer. Highly sorptive radionuclides with short-to-intermediate half-lives also will decay en route to the aquifer. Radionuclides with longer half-lives and those that sorb marginally to vadose zone sediment have a greater likelihood of reaching 
the aquifer. The concentrations in the aquifer, combined with their radiological dose from groundwater ingestion, determine the impact to groundwater.

The design of the facility, including an engineered barrier (cover), and the initial inventory are assumed to be site independent. Thus, the availability of radionuclides for transport from the waste zone is site independent. This allows consideration of a one source model, including desorption of radionuclides from resins, corrosion and dissolution of radionuclides from activated metals, and surface release of waste from contaminated debris. However, the characteristics of vadose zone sediment are site-specific, as is the aquifer velocity. Site-specific parameters include thickness, hydraulic conductivity-moisture content relationships, texture, and sorption characteristics of vadose zone sediment. Dispersion in the aquifer and vadose zone are considered to be site independent.

Because of the large number of radionuclides in the source term and the complexity of the source waste zone and site-specific transport, a four-step analysis approach was used to assess groundwater impacts from the proposed facility. Each step incorporates more complexity and progressively less conservative assumptions to screen out inconsequential radionuclides; therefore, resources can be focused on the radionuclides that have the most impact on groundwater and potential dose. The approach begins with a half-life screening step designed to remove from further consideration those radionuclides that would decay to inconsequential activity levels while enroute to the aquifer. Phase II of the analysis applies screening factors developed by the National Council on Radiation Protection (NCRP; NCRP 1996) to further reduce the inventory of concern to radionuclides that exceed dose limits based on direct ingestion of groundwater prior to transport from the waste zone. Phase III introduces conservative vadose zone transport assumptions, incorporating infiltration, site-specific sediment thicknesses and sorption properties, and site-specific aquifer velocities, while considering instantaneous release from the waste to the top of the vadose zone. Phase IV introduces key characteristics of the waste zone and its effect on the release rate of contaminants into the vadose zone in addition to accounting for dispersivity.

\section{EXPOSURE PATHWAYS AND PERFORMANCE MEASURES}

Exposure scenarios are the link between contaminated environmental media and the exposure of a hypothetical receptor. They are essentially statements and parameter values that describe the behavior of a hypothetical receptor. Only the drinking water scenario was considered in this analysis. This scenario assumes a receptor consumes $2 \mathrm{~L}$ of water per day for 365 days/year per 40 CFR 141, "National Primary Drinking Water Regulations." The receptor is located downgradient of the RH-LLW disposal facility for all times following facility closure; in Phase III screening (described in Section 4.3), the receptor is immediately downgradient of the facility; and in Phase IV, the receptor distance corresponds to the distance required under Department of Energy (DOE) Order 435.1, "Radioactive Waste Management," (100 $\mathrm{m}$ downgradient of the downgradient edge of the facility).

\subsection{Performance Measures}

Groundwater protection standards are determined by the Environmental Protection Agency and the State of Idaho and are couched in terms of maximum contaminant levels (MCLs). Federal MCLs found in 40 CFR 141 include values for beta-gamma emitting radionuclides and alpha-emitting radionuclides. The maximum concentration level for beta-gamma emitting radionuclides is the concentration that, assuming an ingestion rate of $2 \mathrm{~L}$ of water per day for 365 days per year, the dose equivalent to the whole body or critical organ does not exceed $4 \mathrm{mrem} /$ year. Other specific limits include a maximum gross alpha activity of $15 \mathrm{pCi} / \mathrm{L}$ (excluding uranium isotopes), a maximum Ra-226 and Ra-228 concentration of $5 \mathrm{pCi} / \mathrm{L}$, a maximum uranium mass concentration of $30 \mu \mathrm{g} / \mathrm{L}$, and maximum $\mathrm{H}-3$ and Sr-90 concentrations of $20,000 \mathrm{pCi} / \mathrm{L}$ and $8 \mathrm{pCi} / \mathrm{L}$, respectively.

The whole body and critical organ doses are calculated using the dose conversion factors in the National Bureau of Standards Handbook 69, "Maximum Permissible Body Burdens and Maximum 
Permissible Concentration of Radionuclides in Air and Water for Occupational Exposure," (NBS 1963). The dose conversion factors in National Bureau of Standards Handbook 69 are based on International Commission on Radiation Protection Publication 2, which has been superseded by International Commission on Radiation Protection Publication 30, and more recently, International Commission on Radiation Protection Publication 72. Dose conversion factors from the National Bureau of Standards Handbook 69 for all radionuclides in the RH-LLW inventory are not available.

Where the MCL is unpublished, a dose of $4.0 \mathrm{mrem} / \mathrm{year}$ effective dose equivalent (EDE) was used in this analysis to compute the corresponding MCL. The EDE is calculated assuming a 2-L/day ingestion rate for 365 days per year, using dose conversion factors in Federal Guidance Report 13 (EPA 1999). For reference, EDE from direct drinking water ingestion is provided for Phase IV results and is computed using dose conversion factors in Federal Guidance Report 13 (EPA 1999). The groundwater ingestion dose for both calculations is done using the following formula:

$D=C_{G W} * U_{W} * D C F$

where

$D=$ dose (cumulative EDE) from 1 year's consumption of contaminated media, in this case groundwater (mrem/year)

$C_{G W}=$ radionuclide concentration in groundwater $(\mathrm{Ci} / \mathrm{L})$

$U_{W}=$ human consumption rate of water (L/year)

$D C F=$ ingestion dose conversion factor $(\mathrm{mrem} / \mathrm{Ci})$.

The MCL corresponds to the $C_{G W}$, where $D=4.0 \mathrm{mrem} / \mathrm{year}$. Computation of radionuclide-specific concentrations in groundwater for each radionuclide is described in the Phase III and Phase IV screening steps.

\subsection{Facility Design and Operation}

According to the conceptual design report (INL 2010a), the proposed INL RH-LLW disposal facility will accept two primary types of RH-LLW: activated metals and ion-exchange resins. Small amounts of miscellaneous debris waste also will be included. The waste will be contained in sealed liners made of steel. The liners will be placed in concrete disposal vaults at the disposal facility. The disposal vaults will be constructed as precast concrete cylinders (i.e., pipe sections) stacked on end and placed in a closepacked array as shown in Figure 3. All vaults will be supported by reinforced concrete base sections placed atop a gravel layer and covered with removable hexagonal precast concrete plugs. The plugs serve as a radiation shield for emplaced waste and should help prevent water from entering the vaults. The area around the vaults will be backfilled with sand for stability and to promote drainage away from the facility.

During the 2016 through 2065 operational period, the containers and vaults will provide sufficient barriers from water and air such that negligible transport of contaminants into the environment will occur. At the end of the operational period, the disposal facility will be closed.

At the end of the operational life of the disposal facility, a protective cover will be placed over the waste disposal vaults (Figure 4). The primary purposes of the cover are to (1) minimize infiltration into the disposal facility after facility closure, reducing leachate generation and contaminant transport, and (2) provide a barrier against intrusion. In addition to infiltration and intrusion-limiting features, the cover will include armoring on the sides to prevent wind and rain erosion. The cover will be configured to divert surface water away from the vaults and extend beyond the boundary of the facility. The cover dimensions, layer thicknesses, and other specifications will be determined prior to facility closure and be based on the final size and configuration of the facility. The cover also will incorporate criteria identified in the facility performance assessment. 


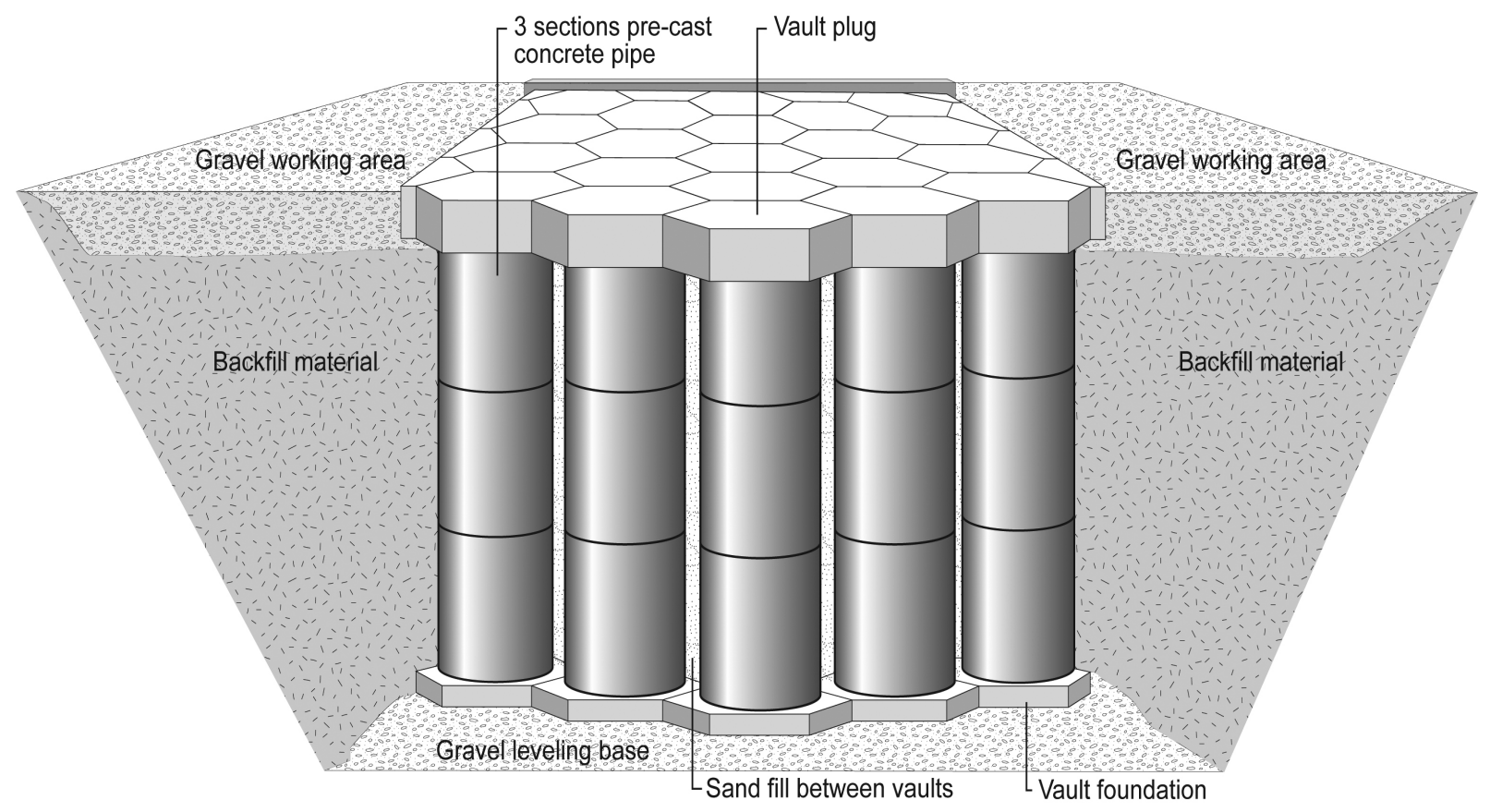

Figure 3. Example of concrete vault layout (INL 2010a).

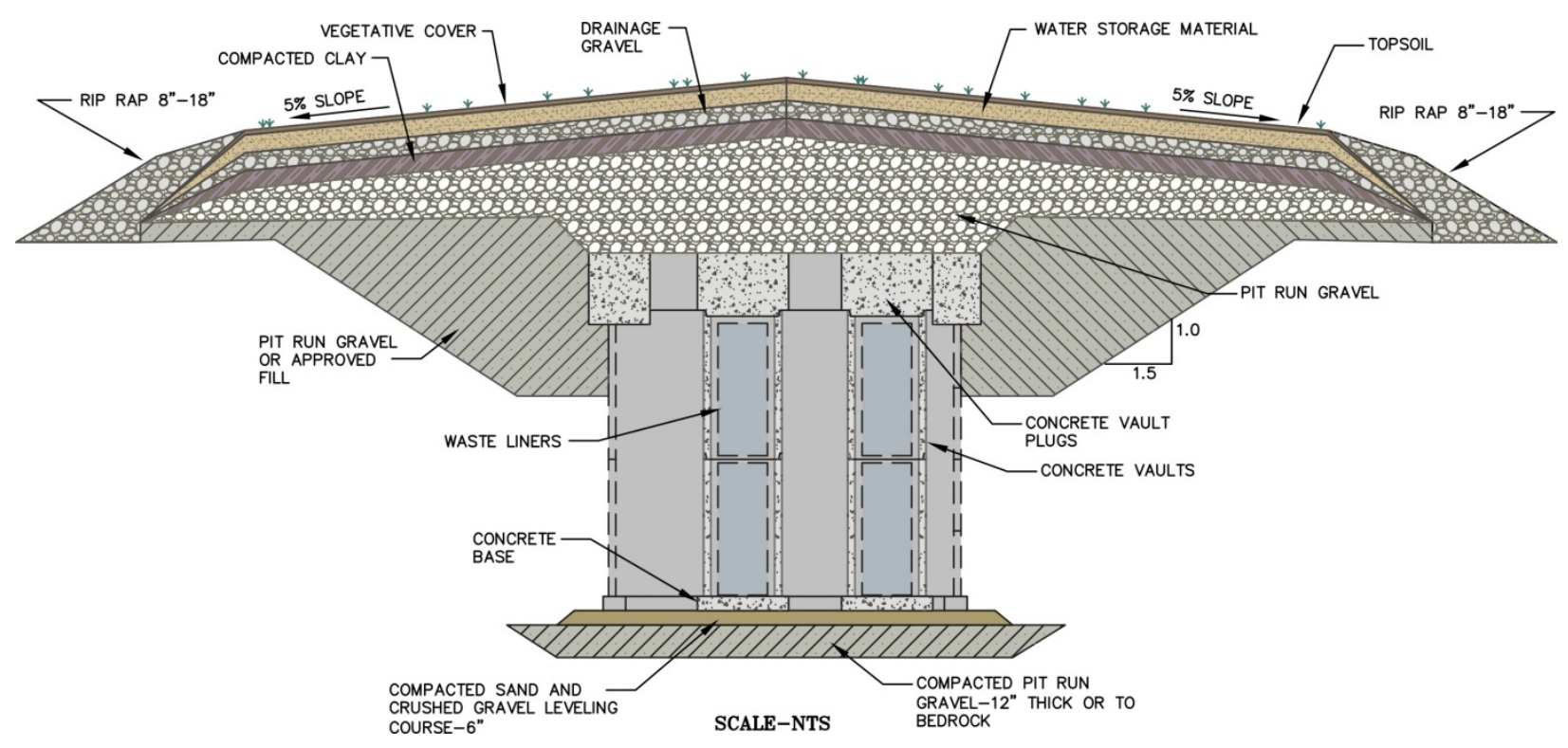

Figure 4. Preliminary cover design for the Idaho National Laboratory remote-handled low-level waste disposal facility.

\section{SOURCE INVENTORY}

The disposal facility will accept three primary types of RH-LLW: activated metals, ion-exchange resins, and miscellaneous contaminated debris. The activated metals are generated by ATR Complex operations, Naval Reactors Facility operations, and from processing waste stored in the Radioactive Scrap and Waste Facility at the Materials and Fuels Complex. The activated metals are typically reactor core components replaced during core internal changeouts and are made from stainless steel, inconel, zircaloy, or aluminum. The ion-exchange resins are ceramic beads used to purify reactor cooling water as part of routine operations at the Naval Reactors Facility and the ATR Complex. 
The design life of the proposed RH-LLW disposal facility is 50 years. Disposal inventories for a 50 -year period have been projected by each of the waste generators; the combined inventory from all generators, in terms of activity, is shown in Table 1. The following is a list and description of the inventory reports produced by the waste generators:

1. Estimate of the Radionuclide Content of Future Activated Metal Generation at ATR from 2016 to 2065 (ECAR-854 2009). This report includes the projected inventory of activation in reactor hardware from core internal changeouts of the ATR. The changeouts occur approximately every 10 years. Over a 50-year period, it is assumed that the waste from six changeouts would be disposed of at the proposed RH-LLW facility.

2. Estimate of Radionuclide Content of Future Resins Generation at ATR from 2016 to 2065 (ECAR-851 2009). This report estimates that approximately $1,200 \mathrm{~m}^{3}$ of radioactively contaminated ion-exchange resins would be generated over a 50 -year period.

3. Long-Range Radioactivity Estimate for the Naval Reactors Facility RH-LLW (NRF 2010). This report includes projections of activation and fission products in activated metals and resins for a 50 -year period. The metal inventory differentiates the amount integral to the metal and the amount on the surface.

4. A Methodology for Retrofitting Source Terms to Previously Inadequately Characterized Experimental Breeder Reactor-II Irradiated Reactor Hardware as Waste (Source Term and Volume Estimate for Materials and Fuels Complex-Generated RH-LLW from 2016 to 2065 (ECAR-904 2010). This report includes an estimate of the radionuclide inventory in Experimental Breeder Reactor-II irradiated hardware currently stored at the Radioactive Scrap and Waste Facility.

5. Source Term and Volume Estimate for Materials and Fuels Complex Generated RH-LLW from 2016 to 2065 (ECAR-967 2010). This report includes the radionuclide inventory in/on miscellaneous debris and trash that is 1) currently stored at the Radioactive Scrap and Waste Facility (legacy waste) and 2) will be generated over the next 50 years from routine operations at the Materials and Fuels Complex (future generation waste).

Table 1. Projected 50-year inventory of remote-handled low-level waste.

\begin{tabular}{lclclc}
\hline Radionuclide & $\begin{array}{c}\text { Total Inventory } \\
(\mathrm{Ci})\end{array}$ & Radionuclide & $\begin{array}{c}\text { Total Inventory } \\
(\mathrm{Ci})\end{array}$ & Radionuclide & $\begin{array}{c}\text { Total Inventory } \\
(\mathrm{Ci})\end{array}$ \\
\hline Ac-225 & $5.63 \mathrm{E}-08$ & In-115 & $4.91 \mathrm{E}-13$ & Re-187 & $8.94 \mathrm{E}-01$ \\
Ac-227 & $1.77 \mathrm{E}-06$ & In-115m & $1.23 \mathrm{E}-09$ & Re-188 & $7.49 \mathrm{E}-01$ \\
Ac-228 & $2.60 \mathrm{E}-07$ & Ir-192 & $1.02 \mathrm{E}-01$ & Rh-102 & $1.16 \mathrm{E}-04$ \\
Ag-108 & $2.53 \mathrm{E}-06$ & Ir-192m & $9.26 \mathrm{E}-06$ & Rh-103m & $4.84 \mathrm{E}-02$ \\
Ag-108m & $2.80 \mathrm{E}-05$ & Ir-194 & $3.60 \mathrm{E}-09$ & Rh-106 & $3.11 \mathrm{E}+03$ \\
Ag-109m & $2.73 \mathrm{E}-01$ & Ir-194m & $1.07 \mathrm{E}-02$ & Rn-219 & $1.77 \mathrm{E}-06$ \\
Ag-110 & $8.04 \mathrm{E}-04$ & K-40 & $1.26 \mathrm{E}-03$ & Rn-220 & $2.97 \mathrm{E}-04$ \\
Ag-110m & $1.12 \mathrm{E}-01$ & K-42 & $5.51 \mathrm{E}-12$ & Rn-222 & $5.22 \mathrm{E}-11$ \\
Ag-111 & $4.70 \mathrm{E}+03$ & Kr-81 & $4.88 \mathrm{E}-12$ & Ru-103 & $8.28 \mathrm{E}+04$ \\
Am-241 & $7.63 \mathrm{E}-01$ & Kr-85 & $2.64 \mathrm{E}+02$ & Ru-106 & $3.11 \mathrm{E}+03$ \\
Am-242 & $2.07 \mathrm{E}-03$ & La-137 & $1.96 \mathrm{E}-06$ & S-35 & $5.85 \mathrm{E}+00$ \\
Am-242m & $2.11 \mathrm{E}-03$ & La-140 & $8.70 \mathrm{E}+04$ & Sb-124 & $5.64 \mathrm{E}+00$ \\
Am-243 & $8.58 \mathrm{E}-04$ & Lu-176 & $1.45 \mathrm{E}-08$ & Sb-125 & $2.96 \mathrm{E}+04$ \\
\hline
\end{tabular}


Table 1. (continued).

\begin{tabular}{|c|c|c|c|c|c|}
\hline Radionuclide & $\begin{array}{c}\text { Total Inventory } \\
(\mathrm{Ci})\end{array}$ & Radionuclide & $\begin{array}{l}\text { Total Inventory } \\
\text { (Ci) }\end{array}$ & Radionuclide & $\begin{array}{c}\text { Total Inventory } \\
\text { (Ci) }\end{array}$ \\
\hline Ar-37 & $1.29 \mathrm{E}-02$ & Lu-177 & $1.20 \mathrm{E}-02$ & $\mathrm{Sb}-126$ & $2.05 \mathrm{E}-05$ \\
\hline Ar-39 & 4.96E-02 & Lu-177m & $5.47 \mathrm{E}-02$ & $\mathrm{Sb}-126 \mathrm{~m}$ & $1.47 \mathrm{E}-04$ \\
\hline Ar-42 & $5.51 \mathrm{E}-12$ & Mn-54 & $8.71 \mathrm{E}+05$ & Sc-46 & $5.30 \mathrm{E}+00$ \\
\hline As-76 & $2.07 \mathrm{E}-02$ & Mo-93 & $2.92 \mathrm{E}+01$ & Se-75 & $1.46 \mathrm{E}+01$ \\
\hline At-217 & 5.63E-08 & Mo-99 & $8.20 \mathrm{E}-01$ & Se-79 & $8.38 \mathrm{E}-03$ \\
\hline Ba-133 & $1.90 \mathrm{E}-03$ & $\mathrm{Na}-24$ & $9.21 \mathrm{E}-06$ & $\mathrm{Si}-32$ & $6.68 \mathrm{E}-07$ \\
\hline Ba-136m & $3.43 \mathrm{E}-10$ & $\mathrm{Nb}-92$ & $5.67 \mathrm{E}-06$ & Sm-147 & $4.11 \mathrm{E}-10$ \\
\hline Ba-137m & $5.93 \mathrm{E}+03$ & $\mathrm{Nb}-93 \mathrm{~m}$ & $5.83 \mathrm{E}+02$ & Sm-151 & $4.86 \mathrm{E}+01$ \\
\hline Ba-140 & $7.60 \mathrm{E}+04$ & $\mathrm{Nb}-94$ & $1.09 \mathrm{E}+02$ & Sn-113 & $4.14 \mathrm{E}+03$ \\
\hline Be-10 & $1.53 \mathrm{E}-04$ & $\mathrm{Nb}-95$ & $2.24 \mathrm{E}+05$ & Sn-117m & $7.53 \mathrm{E}+02$ \\
\hline $\mathrm{Bi}-208$ & $2.52 \mathrm{E}-07$ & $\mathrm{Nb}-95 \mathrm{~m}$ & $5.08 \mathrm{E}+02$ & Sn-119m & $4.15 \mathrm{E}+04$ \\
\hline $\mathrm{Bi}-210 \mathrm{~m}$ & $8.55 \mathrm{E}-07$ & Nd-147 & $3.86 \mathrm{E}+04$ & Sn-121 & $9.57 \mathrm{E}+01$ \\
\hline Bi-211 & $1.77 \mathrm{E}-06$ & $\mathrm{Ni}-59$ & $3.27 \mathrm{E}+03$ & $\mathrm{Sn}-121 \mathrm{~m}$ & $1.23 \mathrm{E}+02$ \\
\hline $\mathrm{Bi}-212$ & $2.95 \mathrm{E}-04$ & $\mathrm{Ni}-63$ & $3.98 \mathrm{E}+05$ & Sn-123 & $1.98 \mathrm{E}+01$ \\
\hline Bi-213 & $5.63 \mathrm{E}-08$ & Np-235 & $2.28 \mathrm{E}-09$ & Sn-125 & $1.04 \mathrm{E}+03$ \\
\hline Bi-214 & $5.22 \mathrm{E}-11$ & Np-236 & $1.04 \mathrm{E}-11$ & Sn-126 & $1.50 \mathrm{E}-04$ \\
\hline Bk-249 & $2.05 \mathrm{E}-09$ & Np-237 & $2.99 \mathrm{E}-03$ & Sr- 85 & $6.28 \mathrm{E}-04$ \\
\hline $\mathrm{C}-14$ & $4.12 \mathrm{E}+02$ & Np-238 & $9.25 \mathrm{E}-06$ & Sr- 89 & $8.45 \mathrm{E}+04$ \\
\hline $\mathrm{Ca}-41$ & $1.36 \mathrm{E}-02$ & Np-239 & 8.39E-04 & Sr-90 & $6.18 \mathrm{E}+03$ \\
\hline $\mathrm{Ca}-45$ & $7.55 \mathrm{E}-01$ & $\mathrm{~Np}-240 \mathrm{~m}$ & $1.02 \mathrm{E}-12$ & Тa-180 & $6.97 \mathrm{E}-01$ \\
\hline Cd-109 & $3.05 \mathrm{E}-01$ & Os-185 & 2.03E-04 & Тa-182 & $5.03 \mathrm{E}+04$ \\
\hline Cd-113m & $3.95 \mathrm{E}-02$ & Os-191 & $2.70 \mathrm{E}-08$ & Tb-160 & $2.61 \mathrm{E}-04$ \\
\hline Cd-115 & $2.69 \mathrm{E}-02$ & Os-194 & $3.58 \mathrm{E}-09$ & Tc-99 & $1.67 \mathrm{E}+01$ \\
\hline $\mathrm{Cd}-115 \mathrm{~m}$ & $6.82 \mathrm{E}-05$ & P-32 & $6.88 \mathrm{E}-06$ & Te-121 & $6.34 \mathrm{E}-03$ \\
\hline Ce-139 & $5.46 \mathrm{E}-04$ & P-33 & $6.06 \mathrm{E}-02$ & Te- $121 \mathrm{~m}$ & $6.38 \mathrm{E}-03$ \\
\hline $\mathrm{Ce}-141$ & $1.04 \mathrm{E}+05$ & $\mathrm{~Pa}-231$ & $8.77 \mathrm{E}-06$ & Te-123 & $2.66 \mathrm{E}-09$ \\
\hline Ce-142 & 4.73E-07 & $\mathrm{Pa}-233$ & $2.05 \mathrm{E}-04$ & Te-123m & $3.21 \mathrm{E}-02$ \\
\hline Ce-144 & $3.78 \mathrm{E}+04$ & $\mathrm{~Pa}-234$ & $1.96 \mathrm{E}-07$ & Te- $125 \mathrm{~m}$ & $7.30 \mathrm{E}+03$ \\
\hline Cf-249 & $5.66 \mathrm{E}-12$ & $\mathrm{~Pa}-234 \mathrm{~m}$ & $1.79 \mathrm{E}-04$ & Te-127 & $5.01 \mathrm{E}-01$ \\
\hline Cf- 250 & $1.46 \mathrm{E}-10$ & $\mathrm{~Pb}-204$ & $4.72 \mathrm{E}-13$ & Te- $127 \mathrm{~m}$ & $6.07 \mathrm{E}+02$ \\
\hline Cf-251 & $1.26 \mathrm{E}-13$ & $\mathrm{~Pb}-205$ & $8.23 \mathrm{E}-07$ & Te-129 & $2.52 \mathrm{E}-04$ \\
\hline Cf- 252 & $3.27 \mathrm{E}-10$ & $\mathrm{~Pb}-209$ & $5.63 \mathrm{E}-08$ & Te-129m & $3.18 \mathrm{E}+03$ \\
\hline $\mathrm{Cl}-36$ & $1.54 \mathrm{E}-01$ & $\mathrm{~Pb}-211$ & $1.77 \mathrm{E}-06$ & Te-132 & $5.03 \mathrm{E}+03$ \\
\hline $\mathrm{Cm}-242$ & $7.83 \mathrm{E}+01$ & $\mathrm{~Pb}-212$ & $2.97 \mathrm{E}-04$ & Th-227 & $1.75 \mathrm{E}-06$ \\
\hline $\mathrm{Cm}-243$ & $1.32 \mathrm{E}-03$ & $\mathrm{~Pb}-214$ & $5.22 \mathrm{E}-11$ & Th-228 & $2.98 \mathrm{E}-04$ \\
\hline
\end{tabular}


Table 1. (continued).

\begin{tabular}{|c|c|c|c|c|c|}
\hline Radionuclide & $\begin{array}{l}\text { Total Inventory } \\
(\mathrm{Ci})\end{array}$ & Radionuclide & $\begin{array}{l}\text { Total Inventory } \\
\text { (Ci) }\end{array}$ & Radionuclide & $\begin{array}{l}\text { Total Inventory } \\
\text { (Ci) }\end{array}$ \\
\hline $\mathrm{Cm}-244$ & $8.66 \mathrm{E}-02$ & Pd-107 & $3.07 \mathrm{E}-04$ & Th-229 & $5.63 \mathrm{E}-08$ \\
\hline $\mathrm{Cm}-245$ & $1.36 \mathrm{E}-06$ & Pm-145 & $1.62 \mathrm{E}-10$ & Th-230 & $5.30 \mathrm{E}-08$ \\
\hline $\mathrm{Cm}-246$ & $1.03 \mathrm{E}-06$ & Pm-146 & 6.77E-08 & Th-231 & 4.26E-06 \\
\hline $\mathrm{Cm}-247$ & $1.89 \mathrm{E}-13$ & Pm-147 & $8.79 \mathrm{E}+03$ & Th-232 & $2.80 \mathrm{E}-07$ \\
\hline $\mathrm{Cm}-248$ & $5.98 \mathrm{E}-13$ & Pm-148 & $2.60 \mathrm{E}-05$ & Th-234 & $1.79 \mathrm{E}-04$ \\
\hline Co-57 & $3.89 \mathrm{E}-01$ & Pm-148m & 4.82E-04 & Tl-204 & $2.19 \mathrm{E}-22$ \\
\hline Co-58 & $1.08 \mathrm{E}+06$ & Po-210 & $2.86 \mathrm{E}-01$ & Tl-206 & $6.08 \mathrm{E}-03$ \\
\hline Co-60 & $2.90 \mathrm{E}+06$ & Po-211 & $2.57 \mathrm{E}-09$ & Tl-207 & $1.77 \mathrm{E}-06$ \\
\hline $\mathrm{Cr}-51$ & $9.92 \mathrm{E}+05$ & Po-212 & $1.90 \mathrm{E}-04$ & Tl-208 & $1.07 \mathrm{E}-04$ \\
\hline Cs-134 & $3.59 \mathrm{E}+02$ & Po-213 & $5.50 \mathrm{E}-08$ & Tl-209 & $2.90 \mathrm{E}-10$ \\
\hline Cs-135 & $1.54 \mathrm{E}-02$ & Po-214 & $5.22 \mathrm{E}-11$ & Tm-170 & $4.77 \mathrm{E}-11$ \\
\hline Cs-136 & $3.09 \mathrm{E}-09$ & Po-215 & $1.77 \mathrm{E}-06$ & Tm-171 & $2.74 \mathrm{E}-07$ \\
\hline Cs-137 & $6.27 \mathrm{E}+03$ & Po-216 & 2.97E-04 & $\mathrm{U}-232$ & $3.63 \mathrm{E}-04$ \\
\hline Eu-152 & $1.02 \mathrm{E}+01$ & Po-218 & $5.22 \mathrm{E}-11$ & $\mathrm{U}-233$ & $1.19 \mathrm{E}-04$ \\
\hline Eu-154 & $2.44 \mathrm{E}+02$ & Pr-143 & $8.74 \mathrm{E}-08$ & $\mathrm{U}-234$ & $1.08 \mathrm{E}-03$ \\
\hline Eu-155 & $3.90 \mathrm{E}+02$ & Pr-144 & $8.17 \mathrm{E}+04$ & $\mathrm{U}-235$ & $5.14 \mathrm{E}-03$ \\
\hline Eu-156 & 8.27E-08 & $\operatorname{Pr}-144 m$ & $3.85 \mathrm{E}-01$ & U-236 & $1.23 \mathrm{E}-04$ \\
\hline $\mathrm{Fe}-55$ & $1.19 \mathrm{E}+06$ & Pt-193 & $8.74 \mathrm{E}-04$ & U-237 & 4.64E-04 \\
\hline $\mathrm{Fe}-59$ & $1.19 \mathrm{E}+05$ & $\mathrm{Pu}-236$ & 5.92E-07 & $\mathrm{U}-238$ & $1.62 \mathrm{E}+01$ \\
\hline Fr-221 & $5.63 \mathrm{E}-08$ & $\mathrm{Pu}-237$ & 4.54E-08 & U-240 & $1.02 \mathrm{E}-12$ \\
\hline Fr-223 & $1.33 \mathrm{E}-08$ & $\mathrm{Pu}-238$ & $1.21 \mathrm{E}+00$ & V-50 & $2.51 \mathrm{E}-11$ \\
\hline Gd-153 & $3.36 \mathrm{E}-01$ & $\mathrm{Pu}-239$ & 4.10E-01 & W-181 & $5.09 \mathrm{E}+01$ \\
\hline $\mathrm{H}-3$ & $3.88 \mathrm{E}+03$ & $\mathrm{Pu}-240$ & $1.99 \mathrm{E}-01$ & W-185 & $2.70 \mathrm{E}+02$ \\
\hline Hf-175 & $1.90 \mathrm{E}+02$ & $\mathrm{Pu}-241$ & $2.36 \mathrm{E}+01$ & W-187 & 8.94E-01 \\
\hline Hf-181 & $1.35 \mathrm{E}+02$ & $\mathrm{Pu}-242$ & $2.99 \mathrm{E}-04$ & W-188 & $1.35 \mathrm{E}-01$ \\
\hline Hf-182 & $1.08 \mathrm{E}-04$ & $\mathrm{Pu}-244$ & $9.65 \mathrm{E}-13$ & $\mathrm{Xe}-131 \mathrm{~m}$ & $1.42 \mathrm{E}-10$ \\
\hline Ho-166m & $5.10 \mathrm{E}-08$ & Ra-223 & $1.77 \mathrm{E}-06$ & Xe-133 & $3.34 \mathrm{E}+04$ \\
\hline I-129 & $1.33 \mathrm{E}-01$ & Ra-224 & 2.97E-04 & $Y-89 m$ & $3.41 \mathrm{E}-04$ \\
\hline $\mathrm{I}-131$ & $2.52 \mathrm{E}+04$ & $\mathrm{Ra}-225$ & $5.63 \mathrm{E}-08$ & Y-90 & $6.18 \mathrm{E}+03$ \\
\hline I-132 & $5.46 \mathrm{E}-03$ & Ra-226 & $5.22 \mathrm{E}-11$ & Y-91 & $1.06 \mathrm{E}+05$ \\
\hline I-133 & $2.16 \mathrm{E}-02$ & $\mathrm{Ra}-228$ & $2.60 \mathrm{E}-07$ & $\mathrm{Zn}-65$ & $1.37 \mathrm{E}+02$ \\
\hline In-113m & $4.14 \mathrm{E}+03$ & $\mathrm{Rb}-86$ & $2.25 \mathrm{E}-06$ & Zr-93 & $4.03 \mathrm{E}+01$ \\
\hline In-114 & $3.70 \mathrm{E}+00$ & $\mathrm{Rb}-87$ & $1.03 \mathrm{E}-06$ & Zr-95 & $1.73 \mathrm{E}+05$ \\
\hline In-114m & $3.87 \mathrm{E}+00$ & Re-186 & $6.35 \mathrm{E}-06$ & & \\
\hline
\end{tabular}




\section{EVALUATION APPROACH}

Because of the large number of radionuclides identified in the inventory estimates, a four-phase evaluation approach was used to screen out and assess potential groundwater impacts. The first two phases use very simple and conservative site-independent screening methods to eliminate inconsequential radionuclides from further consideration. The third phase uses a conservative model to simulate the release and transport of radionuclides through the subsurface to a hypothetical receptor. The fourth phase incorporates release of radionuclides from specific waste forms, sorption within the waste zone, site-specific sorption parameters for sedimentary interbeds, vadose zone and aquifer dispersion, and the influence of an engineered infiltration reducing cover. Results of Phase III and Phase IV are compared to the MCLs. The details of each screening phase are described in the following subsections.

\subsection{Phase I: Radionuclide Half-Life Screening}

Phase I identifies radionuclides with half-lives sufficiently small that decay would reduce the activity to insignificant levels by the time the radionuclide reaches the aquifer. The resultant activity after transport through the vadose zone is computed from the vadose zone transit time (T) and the half life of each radionuclide $(\mathrm{t} 1 / 2)$ :

$\mathrm{A}(\mathrm{t})=\mathrm{A}_{0} * \mathrm{e}^{-\lambda \mathrm{T}} \quad$ where $\quad \lambda=\frac{\ln (2)}{t_{1 / 2}}$

Where $A(t)$ is the activity at time $t, A_{0}$ is the initial activity, and $\lambda$ is the radioactive decay constant.

The transit time through the vadose zone for a non-sorbing tracer is approximately 30 years based on an average INL sediment thickness, a background infiltration rate of $10 \mathrm{~cm} /$ year representative of disturbed soil conditions (DOE-ID 1994, DOE-ID 2007a), and representative soil hydraulic characteristics (moisture content). Using Equation 2, after 30 years, a radionuclide with a 5-year half-life would have $1.5 \times 10^{-2}$ times its original activity, and a radionuclide with a 1 -year half-life would have $9.3 \times 10^{-10}$ times the original activity. In the results presented in Section 5, a cut-off of 1 year is applied. Adopting a 1-year cut-off is consistent with the Idaho CERCLA Disposal Facility Performance Assessment (ICDF; DOE-ID 2010) where a half-life cut-off of 1 year also was applied. Additionally, the 1-year cut-off is consistent with the NCRP groundwater screening approach (NCRP 1996).

\subsection{Phase II: National Council on Radiation Protection Screening}

The NCRP provides a series of simple screening techniques and factors that can be used to demonstrate compliance with environmental standards or other administratively set reference levels for releases of radionuclides to the atmosphere, surface water, or groundwater (NCRP 1996). The screening factor is essentially a dose conversion factor having units of total EDE per unit of activity ( $\mathrm{Sv} / \mathrm{Bq}$ or $\mathrm{rem} / \mathrm{Ci}$ ). These factors incorporate radionuclide fate and transport processes and an assumed exposure scenario to calculate the annual total EDE to a hypothetical receptor per unit of activity in the radionuclide inventory. The screening factors applicable to groundwater exposure consider leaching and subsequent dilution of radionuclides in groundwater from a generic waste site. Factors are calculated for delay times of $0,2,10,30,100$, and 1,000 years. During the delay time, radionuclide inventories are only depleted by radioactivity decay. The maximum of the six values is then reported in the screening factor tables for groundwater.

This analysis essentially has the entire waste inventory susceptible to leaching over the period of 1 year into a water volume equal to the annual average per capita use of groundwater in rural regions of the United States (i.e., $91,000 \mathrm{~L}$ ). The receptor is then assumed to drink $800 \mathrm{~L}$ of this contaminated water over the period of a year and their dose is computed for that intake. The screening factor for groundwater is given by (NCRP 1996): 
$S F=\lambda_{L} A_{o} \frac{U_{D W}}{V} \sum_{i=0}^{N} X_{i} D C F_{i n g, i}$

where

$\mathrm{SF}=$ groundwater screening factor $(\mathrm{Sv} / \mathrm{Bq})$

$\lambda_{\mathrm{L}}=$ leach rate constant (year-1)

$\mathrm{A}_{\mathrm{o}}=$ initial activity $(\mathrm{Bq})$

$\mathrm{U}_{\mathrm{DW}}=$ consumption of drinking water (assumed to be $800 \mathrm{~L} / \mathrm{year}$ )

$\mathrm{V}=$ dilution volume (assumed to be $91,000 \mathrm{~L}$ )

$\mathrm{X}_{\mathrm{i}}=$ annual average fraction of the original parent activity for decay chain member $\mathrm{i}$

$\mathrm{DCF}_{\text {ing }}=$ ingestion dose conversion factor $(\mathrm{Sv} / \mathrm{Bq})$

$\mathrm{N}=$ number of progeny in the decay chain.

Assuming there is $100 \%$ containment of the waste during delay time and the release of radioactivity is averaged over the first year of release following the delay time, the fraction of the original parent activity leached to the dilution volume over a year for the parent $\left(\mathrm{X}_{0}\right)$ is given by:

$\mathrm{X}_{0}=\frac{\left(1-\mathrm{e}^{-\left(\lambda+\lambda_{0}^{\mathrm{r}}\right) \mathrm{T} \text { avg }}\right) \mathrm{e}^{-\lambda_{0} \mathrm{~T}} \mathrm{del}}{\mathrm{T}_{\mathrm{avg}}\left(\lambda_{\mathrm{L}}+\lambda_{0}^{\mathrm{r}}\right)}$

where

$\lambda_{\mathrm{o}}^{\mathrm{r}} \quad=$ radioactive decay rate constant for parent $(1 /$ year $)$

$\mathrm{T}_{\text {avg }}=$ averaging time (1 year)

$\mathrm{T}_{\mathrm{del}}=$ delay time (years).

A typographical error in Equation 4 was noted in the NCRP text. The fraction of progeny activity relative to the parent that is leached to the dilution volume is given by:

$X_{i}=\frac{1}{T_{a v g}}\left(\prod_{j=1}^{K} \lambda_{j}^{r} f_{j}\right) \sum_{h=0}^{N} \frac{\left(1-e^{-\lambda_{h}^{r} T_{a v g}}\right) e^{\lambda_{h}^{r} T_{d e l}}}{\lambda_{h}^{r} \prod_{\substack{\mathrm{K}=0 \\ p \neq h}}^{\mathrm{N}}\left(\lambda_{\mathrm{p}}^{\mathrm{r}}+\lambda_{\mathrm{h}}^{\mathrm{r}}\right)}$

where

$\mathrm{f}_{\mathrm{j}} \quad=$ fraction of parent decaying to jth progeny

$\lambda_{\mathrm{h}}^{\mathrm{r}} \quad=$ radioactive decay rate constant for jth progeny parent $(1 /$ year $)$.

The leach rate constant $\left(\lambda_{\mathrm{L}}\right)$ is taken from a formulation described in Baes and Sharp (1983) and used in the models RESRAD (Yu et al. 2001), MEPAS (Whelan et al. 1996), and GWSCREEN (Rood 2003).

The leach rate constant is given by:

$\lambda_{\mathrm{L}}=\frac{\mathrm{I}}{\mathrm{H} \theta\left(\mathrm{I}+\frac{\mathrm{K}_{\mathrm{d}} \rho}{\theta}\right)}$

where

$\mathrm{I}=$ assumed infiltration rate $(18 \mathrm{~cm} /$ year $)$

$\mathrm{H}=$ assumed waste thickness $(0.5 \mathrm{~m})$

$\rho=$ bulk density $(\mathrm{cm} 3 / \mathrm{g})$

$\mathrm{Kd}=$ sorption coefficient $(\mathrm{cm} 3 / \mathrm{g})$ 
$\theta=$ moisture content $\left(0.3 \mathrm{~m}^{3} / \mathrm{m}^{3}\right)$.

Values for the sorption coefficients used in the NCRP screening were taken from Kennedy and Strenge (1992). The assumed infiltration rate represents the upper-bound infiltration rate determined for low-level radioactive waste sites located in the southeastern United States. For comparison, the infiltration rate at INL into disturbed soils is less than $10 \mathrm{~cm} /$ year.

The assumption is made in Equation 4 that the unsaturated travel time is instantaneous. For INL, this is an extremely conservative assumption because unsaturated contaminant travel times have been estimated to take from several years to hundreds of thousands of years depending on the sorption properties of the contaminant. Under these assumptions, the NCRP groundwater screening model provides a conservative estimate of the potential dose.

Results shown in Section 5 retain radionuclides with an NCRP screening dose greater than $0.4 \mathrm{mrem} / \mathrm{year}$ for further consideration. The NCRP screening dose is calculated by multiplying the radionuclide inventory by the NCRP screening dose factor. For example, the NCRP screening dose for Co-60 is:

$\mathrm{SD}=\left(1.48 \times 10^{-6} \mathrm{Ci}\right) \times\left(2.442 \times 10^{-3} \frac{\mathrm{rem}}{\mathrm{Ci}}\right)=6.73 \times 10^{3} \mathrm{rem}$.

NCRP screening factors are unavailable for some radionuclides with extremely long half-lives (i.e., half-lives that are essentially a stable isotope [e.g., Nd-144, $\mathrm{T}^{1 / 2}=5 \times 10^{15}$ years]), and are unavailable where exposure via groundwater is limited by the physical form of the radionuclide (e.g., $\mathrm{Kr}-85$ ). In these two cases, the radionuclides are screened from the inventory because ingestion dose factors are unavailable.

\subsection{Phase III: Site-Specific Transport Screening}

This step accounts for leaching, advection, dispersion, and radioactive chain decay and ingrowth. A one-dimensional transport model is used to determine leaching from the source, transport through the vadose zone, and dilution and dispersion in the aquifer as illustrated in Figure 5. This model provides the concentrations in the aquifer and groundwater ingestion dose at a user-defined receptor location in the aquifer. Predicted aquifer concentrations are compared to federal MCLs. Radionuclides with concentrations less than the MCL are removed from further consideration.

The conceptual model of a one-dimensional unsaturated and saturated zone flow shown in Figure 5 has been implemented for Phase III using the GWSCREEN computer code (Rood 2003). GWSCREEN accounts for leaching from the source, advective transport in the unsaturated zone, sorption, and chain decay. Transport in the saturated zone is calculated with a two-dimensional or three-dimensional semianalytical solution to the advection dispersion equation in groundwater. In this application, the two-dimensional solution was used. Concentrations are vertically averaged over a well screen thickness of $15 \mathrm{~m}$ for a receptor placed at the downgradient edge of the RH-LLW disposal facility.

\subsubsection{Flow and Transport Processes}

Flow through the source and unsaturated zone is assumed to occur only in the aqueous phase under steady-state, unidirectional (downward), and unit gradient conditions. The unsaturated zone is assumed to be a homogeneous isotropic medium of infinite extent. Solid and liquid contaminant phases are assumed to be in equilibrium and related by the linear distribution coefficient $\left(\mathrm{K}_{\mathrm{d}}\right)$. 


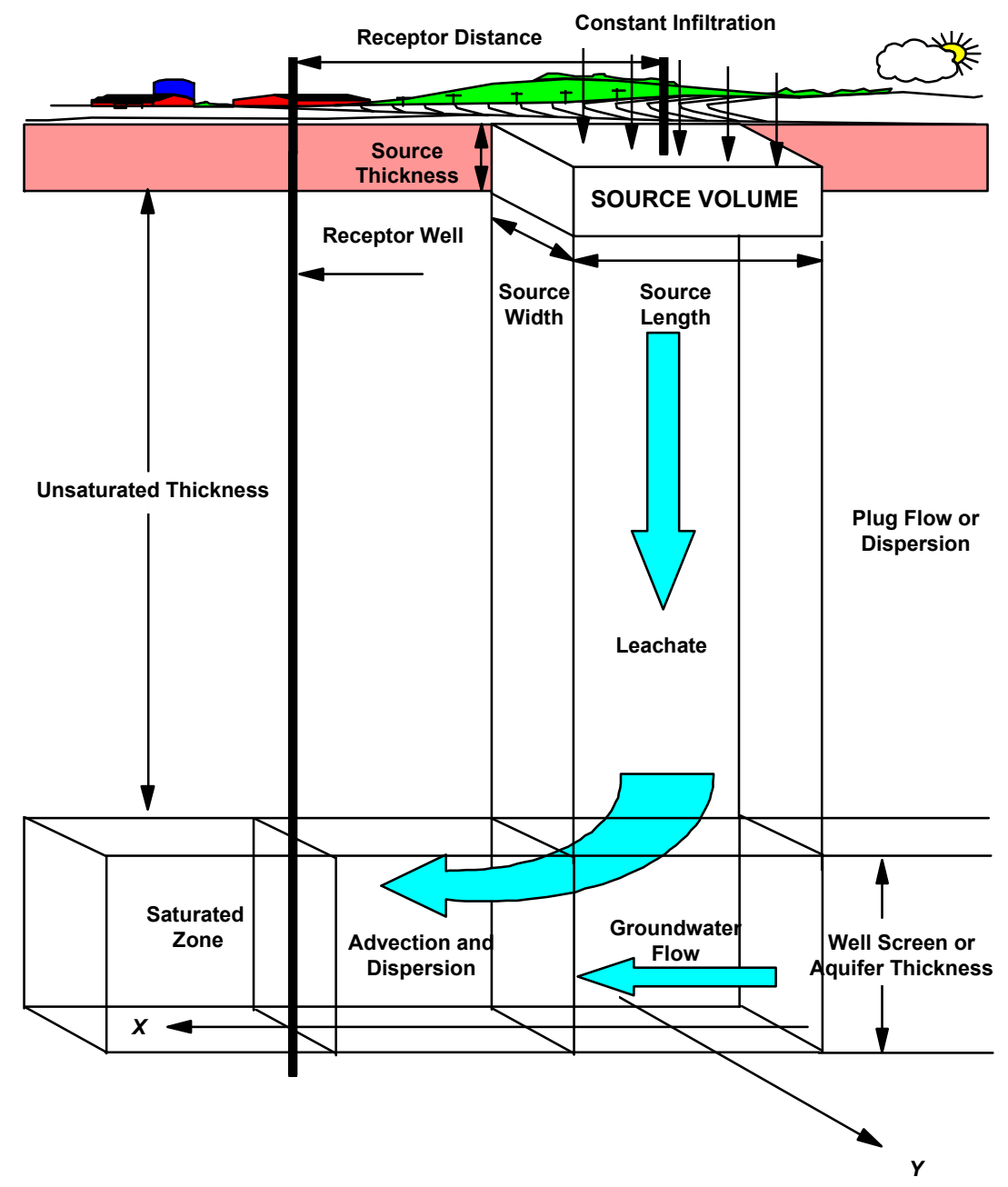

Figure 5. Conceptual model of transport implemented in this analysis.

The mass balance equation describing transport in one-dimension given steady flow is

$\frac{\partial \mathrm{C}}{\partial \mathrm{t}}+\frac{\mathrm{U}_{\mathrm{u}}}{\mathrm{R}_{\mathrm{du}}} \frac{\partial \mathrm{C}}{\partial \mathrm{x}}=\frac{\mathrm{D}_{\mathrm{x}}}{\mathrm{R}_{\mathrm{du}}} \frac{\partial^{2} \mathrm{C}}{\partial \mathrm{x}^{2}}-\lambda_{\mathrm{d}} \mathrm{C}$

where

$\mathrm{C}=$ concentration $\left(\mathrm{mg}\right.$ or $\left.\mathrm{Ci} / \mathrm{m}^{3}\right)$

$\mathrm{R}_{\mathrm{du}}=$ retardation in the unsaturated zone

$\mathrm{U}_{\mathrm{u}}=$ pore velocity (flow in the positive $\mathrm{x}$ direction, $\mathrm{m} / \mathrm{year}$ )

$\mathrm{D}_{\mathrm{x}}=$ dispersion coefficient in the $\mathrm{x}$ direction $\left(\mathrm{m}^{2} /\right.$ year $)$

$\mathrm{t}=$ time (year)

$\mathrm{x}=$ distance traversed parallel to direction of flow (m).

The saturated zone model is represented by the advection dispersion equation for contaminants in a saturated porous medium. The model contains the following assumptions and limitations:

1. The flow is uniform and unidirectional; no sources or sinks are accounted for 
2. The aquifer is modeled as an isotropic, homogeneous porous medium of infinite lateral extent and finite thickness

3. Molecular diffusion is assumed to be negligible

4. Dispersion coefficients remain constant over time

5. Transport is limited to a single species that may decay or degrade as a function of time; radioactive progeny are assumed to travel at the same rate as their parent

6. Solid and liquid phases are in equilibrium and concentrations are related by the linear $\mathrm{K}_{\mathrm{d}}$.

The mass balance equation that describes contaminant transport for the stated assumptions is

$\frac{\partial \mathrm{C}}{\partial \mathrm{t}}+\frac{\mathrm{U}}{\mathrm{R}_{\mathrm{d}}} \frac{\partial \mathrm{C}}{\partial \mathrm{x}}=\frac{\mathrm{D}_{\mathrm{x}}}{\mathrm{R}_{\mathrm{d}}} \frac{\partial^{2} \mathrm{C}}{\partial \mathrm{x}^{2}}+\frac{\mathrm{D}_{\mathrm{y}}}{\mathrm{R}_{\mathrm{d}}} \frac{\partial^{2} \mathrm{C}}{\partial \mathrm{y}^{2}}+\frac{\mathrm{D}_{\mathrm{z}}}{\mathrm{R}_{\mathrm{d}}} \frac{\partial^{2} \mathrm{C}}{\partial \mathrm{z}^{2}}-\lambda_{\mathrm{d}} \mathrm{C}$

where

$\mathrm{C}=$ concentration $\left(\mathrm{mg}\right.$ or $\left.\mathrm{Ci} / \mathrm{m}^{3}\right)$

$\mathrm{U}=$ average linear velocity or groundwater pore velocity $(\mathrm{m} / \mathrm{year})$

$\mathrm{D}_{\mathrm{x}}, \mathrm{D}_{\mathrm{y}}, \mathrm{D}_{\mathrm{z}}=$ dispersion coefficients in the $\mathrm{x}, \mathrm{y}$, and $\mathrm{z}$ direction $\left(\mathrm{m}^{2} / \mathrm{year}\right)$

$\mathrm{R}_{\mathrm{d}}=$ retardation factor in the aquifer

$\mathrm{t}=$ time (year)

$\mathrm{x}=$ distance from center of area source to receptor parallel to groundwater flow $(\mathrm{m})$

$\mathrm{y}=$ distance from center of area source to receptor perpendicular to groundwater flow $(\mathrm{m})$

$\mathrm{z}=$ distance downward from the surface of the aquifer $(\mathrm{m})$.

The retardation factor in the aquifer is given by

$\mathrm{R}_{\mathrm{d}}=1+\frac{\mathrm{K}_{\mathrm{Da}} \rho_{\mathrm{a}}}{\eta}$

where

$\eta=$ the effective porosity of the aquifer $\left(\mathrm{m}^{3} / \mathrm{m}^{3}\right)$

$\mathrm{K}_{\mathrm{Da}}=$ the distribution coefficient in the aquifer $(\mathrm{mL} / \mathrm{g})$

$\rho_{\mathrm{a}}=$ the bulk density in the aquifer $\left(\mathrm{g} / \mathrm{cm}^{3}\right)$.

The dispersion coefficients $\left(D_{x}, D_{y}, D_{z}\right)$ are given by

$D_{\mathrm{x}}=\alpha_{\mathrm{L}} \mathrm{U} \quad \mathrm{D}_{\mathrm{y}}=\alpha_{\mathrm{t}} \mathrm{U} \quad \mathrm{D}_{\mathrm{z}}=\alpha_{\mathrm{v}} \mathrm{U}$

where

$\alpha_{\mathrm{L}}=$ the longitudinal dispersivity (m)

$\alpha_{\mathrm{T}}=$ the transverse dispersivity (m)

$\alpha_{\mathrm{V}}=$ the vertical dispersivity (m).

To evaluate the movement of radioactive progeny, the model makes the simplifying assumption that radioactive progeny travel at the same rate as the parent. This assumption has been shown to be conservative (Codell et al. 1982). 


\subsubsection{Phase III Model Parameterization}

The fundamental process model assumes that contaminants released near land surface could be transported downward through the stratigraphic layers comprising the vadose zone and into the aquifer by infiltration from natural precipitation. Along this transport pathway, the dilute radionuclides can undergo advection, phase-partitioning, sorption, diffusion, dispersion, and radioactive chain decay and ingrowth. Once in the aquifer, similar transport and decay processes occur as contaminants move with the regional groundwater flow. The relative influences of these processes are, in part, determined by site-specific hydrogeochemistry and are, in part, contaminant specific. Advection, dispersion, and sorption are largely determined by the geostratigraphy and localized infiltration at each individual site. Transport and radioactive decay are contaminant specific, with the contaminant inventory dictated by the waste source.

In the Phase III screening approach adopted for this environmental assessment, the important parameters and characteristics are (1) representation of the release from the source zone, (2) infiltration rate, (3) relative sediment abundance, (4) texture of the sedimentary interbeds, and (5) the velocity of water in the aquifer. Conceptualization of waste distribution and performance of the source zone determines the release rate into the upper portion of the vadose zone. The infiltration rate through the source zone fixes the hydraulic conductivity to be equal to the infiltration rate under steady-state, unit-gradient conditions in the vadose zone. Total sediment thickness determines the net sorption occurring along the transport path because it is assumed that no sorption occurs in the basalts and transit time through the basalts is instantaneous. Sediment texture determines the distribution or $\mathrm{K}_{\mathrm{d}}$, bulk density, and moisture content at a given hydraulic conductivity. The moisture content, $\mathrm{K}_{\mathrm{d}}$, and bulk density determine contaminant retardation. Net aquifer concentrations are largely determined by radionuclide flux from the vadose zone compared to the influx of clean water moving with the aquifer velocity. These parameters and characteristics are discussed in the following subsections and are summarized in Table 2.

4.3.2.1 Source Release Model. The facility design incorporates two levels of containment in the facility itself. Waste will be placed into steel liners (canisters) that will be placed into concrete vaults separated by fine-grained soils or sands. At the end of the operational period, the waste vaults will be covered with an infiltration-reducing cap. Early in the facility lifetime, the cover will limit infiltration into the waste zone, the concrete vaults will limit contact of infiltrating water with the steel containers, and the steel containers will limit water contact with the waste. Over time, the infiltration-reducing properties of the cap could degrade, as could the concrete. Additionally, the steel containers could degrade, allowing water contact with the waste forms. Over decades, the waste zone would revert to a mix of radionuclides, soil, and degraded concrete and metal.

Radionuclides will be placed into the proposed facility in different waste forms, with the waste form determining the availability of each species to be transported in the infiltrating water. Radionuclides incorporated into metals will release differentially from those adsorbed onto resins, with the most readily available coming from those on metal surfaces and those disposed of as miscellaneous debris and trash. A complete source release model would account for degradation of the cap, concrete, and steel liners. Additionally, a source release model would differentially account for surface wash, metal corrosion from the metal parts, and desorption from resins. These processes occur over time periods that would allow for natural decay of radionuclides.

The most conservative assumptions would neglect containment provided by the concrete and steel liners, desorption from resins, and corrosion of activated metals, essentially skipping the early and midlife facility phases, resulting in the final, well-mixed assemblage of radionuclides and soils. This source release model will be adopted for both candidate sites. It will be represented in GWSCREEN as a $10-\mathrm{m} \times 120$-m soil-radionuclide mixture $6 \mathrm{~m}$ deep, oriented with the long-axis perpendicular to the aquifer flow direction. Soil properties in this source region will be assumed to be equal to the site-specific properties discussed in the following subsections. 
4.3.2.2 Infiltration Rate. As implied above, during the operational period, infiltration into the facility will not contact the waste emplaced in the steel liners and concrete vaults. After capping the facility, infiltration through the waste zone will be small by design. Over the long term, the infiltration is assumed to revert back to natural conditions as the cap and vault-system degrade.

Infiltration at both sites will be assumed to be $10 \mathrm{~cm} /$ year throughout the duration of the simulations. After facility closure, an infiltration-reducing engineered barrier (cover) will be placed over the facility. The cover will conform to design specifications determined by the facility performance assessment and, in keeping with similar barriers emplaced at INL, is expected to initially limit infiltration to less than $1 \mathrm{~mm} /$ year. During the next 1,000 years, the infiltration rate is expected to increase as the performance of the cover degrades, with the infiltration rate reverting back to conditions representative of INL undisturbed sediments $(1 \mathrm{~cm} /$ year $)$.

For reference, $10 \mathrm{~cm} /$ year is representative of natural infiltration through disturbed sediments across INL. The $10 \mathrm{~cm} /$ year value is the default Track 2 value (DOE-ID 1994) used for groundwater screening assessments of low-impact INL CERCLA sites. For comparison, the total precipitation at INL is on the order of $20 \mathrm{~cm} /$ year. Background infiltration rates outside the Subsurface Disposal Area at RWMC in undisturbed sediments are estimated to be on the order of $1.0 \mathrm{~cm} /$ year (Cecil et al. 1992) or as low as $0.1 \mathrm{~cm} /$ year based on Mattson et al. (2004). Inverse modeling using soil moisture profiles measured with neutron logging coupled with meteorological time histories was used to estimate infiltration at monitoring locations around the SDA (Martian and Magnuson 1994; Martian 1995). These inverse modeling estimates were used in combination with surface topography to assign a distribution of three infiltration rates across the Subsurface Disposal Area (Martian 1995). These three rates are $1 \mathrm{~cm} /$ year (0.4 in./year), which is the same as the background infiltration rate traditionally assumed for undisturbed soil outside the Subsurface Disposal Area; $3.7 \mathrm{~cm} /$ year (1.5 in./year), representing a medium value; and $10.0 \mathrm{~cm} /$ year (4 in./year), representing infiltration through drainage ditches where water and snow are intentionally diverted. The spatial average infiltration used for the RWMC Remedial Investigation and Baseline Risk Assessment (DOE-ID 2006b) was $5 \mathrm{~cm} /$ year. These rates represent net infiltration, or recharge, because the influence of evapotranspiration is included in the inverse modeling (Martian 1995).

The performance period of the proposed RH-LLW facility is 1,000 years, and the vadose zone transit time ranges from 50 to 100,000 s of years. Over longer time periods, natural compaction and weathering processes would return the waste-soil source zone to undisturbed conditions; therefore, assuming $10-\mathrm{cm} /$ year infiltration representative of disturbed conditions throughout the lifetime of the facility is conservative.

4.3.2.3 Relative Sediment Abundance. Geostratigraphy at INL is comprised of interlayered basalts and sedimentary interbeds. The basalts very readily transmit water vertically and they have little adsorptive capacity. In contrast, sediment in the interbeds retains water and serves to retard downward migration of radionuclides. Sediment at both proposed sites contain a mixture of clays, silts, and sands, all of which hold sorptive capacity.

Primary sedimentary interbeds have been identified and extensively characterized through activities supporting CERCLA actions at the ATR Complex and at INTEC (DOE-ID 1997a; DOE-ID 1997b; DOE-ID 2006a; and Helm-Clark et al. 2005). The lateral continuity and variability in sediment thickness at INTEC was evaluated in DOE-ID (2006a) as part of the CERCLA investigation and at the ATR Complex (INL 2010b).

These primary interbeds are shown in cross-sections for proposed Sites 5 and 34 in Figures 6 and 8 . The geologic cross-section adjacent to proposed Site 5 (Figure 1) is shown in Figure 6, with its path shown in Figure 7. The mean cumulative sediment thickness for this site is approximately $20 \mathrm{~m}$ and is based on sedimentary occurrence in the closest eight wells and the geostatistical analysis in INL (2010b). Figure 8 shows a north-south cross-section through INTEC that passes just east of proposed Site 34 
(Figure 9). The mean sediment thickness near Site 34 at INTEC is approximately $17 \mathrm{~m}$ (DOE-ID 2006a, DOE-ID 2010).

4.3.2.4 Sedimentary Interbed Properties. Sediment texture and hydraulic conductivity also have been characterized as part of the INTEC and ATR Complex CERCLA investigations and documented for INTEC (DOE-ID 1997b; DOE-ID 2006a; DOE-ID 2003b). Interbeds at INTEC are generally characterized as sandy silts, with percentages of clay, silt, sand, and gravel equal to 15.7, 44.5, 27.7, and 12.1\%, respectively (DOE-ID 2003b). Sediment comprising the interbeds at Site 5 contains more clay content and very little gravel. Percentages of clay, silt, sand, and gravel at Site 5 are 22.9, 38.6, 37.7, and $0.8 \%$, respectively (Doornbos et al. 1991). The hydraulic constitutive relationships documented for high-permeability sediment in DOE-ID (2006a) were adopted for the analysis of Site 34 . At the $10 \mathrm{~cm} /$ year hydraulic conductivity and infiltration rate, the corresponding moisture content is 0.0979 . At Site 5 , the corresponding moisture content is 0.359 , which is consistent with silt-loams (DOE-ID 2004). For conservatism, the lowest $\mathrm{K}_{d}$ value recommended by DOE-ID (1994), Jenkins (2001) and DOE-ID (2006a) was used.

4.3.2.5 Aquifer Velocity. Aquifer velocities across INL are spatially variable. The composite analysis of INL-wide groundwater CERCLA impacts resulted in a parameterized and calibrated flow model encompassing the INTEC and ATR Complex areas (DOE-ID 2008). The Darcy velocities downgradient of Site 34 are approximately equal to $21.9 \mathrm{~m} /$ year. The eastern region of the proposed Site 5 has a similar Darcy velocity of $21.0 \mathrm{~m} /$ year.

4.3.2.6 Other Model Parameters. Default Track 2 dispersivity values of $9 \mathrm{~m}$ (longitudinal) and $4 \mathrm{~m}$ (transverse) were applied. An aquifer porosity of 0.06 was used, which corresponds to that determined through calibration of the INL-wide groundwater model (DOE-ID 2005; Wood et al. 2007). No dispersivity was applied in the vadose zone. The receptor was assumed to reside at the downgradient edge of the proposed RH-LLW facility boundary.

Table 2. Input parameters used for Phase III screening calculations.

\begin{tabular}{|c|c|c|c|}
\hline $\begin{array}{l}\text { GWSCREE } \\
\text { Variable }\end{array}$ & Parameter Description & Value & Comments \\
\hline \multicolumn{4}{|c|}{ Card 7 (Source) } \\
\hline $\mathrm{L}$ & $\begin{array}{l}\text { Source length parallel to } \\
\text { groundwater flow }\end{array}$ & $10 \mathrm{~m}$ & $\begin{array}{l}\text { Based on RH-LLW facility design. The facility is } \\
\text { assumed to be oriented east-west, which is } \\
\text { perpendicular to regional groundwater flow. }\end{array}$ \\
\hline $\mathrm{W}$ & $\begin{array}{l}\text { Source width } \\
\text { perpendicular to } \\
\text { groundwater flow }\end{array}$ & $120 \mathrm{~m}$ & $\begin{array}{l}\text { Based on RH-LLW facility design. The facility is } \\
\text { assumed to be oriented east-west, which is } \\
\text { perpendicular to regional groundwater flow. }\end{array}$ \\
\hline PERC & $\begin{array}{l}\text { Percolation rate through } \\
\text { source into vadose zone }\end{array}$ & $0.1 \mathrm{~m} /$ year & DOE-ID (1994, p. C-11) \\
\hline \multicolumn{4}{|c|}{ Card 8b (Source) } \\
\hline THICKS & Thickness of source & $6 \mathrm{~m}$ & Based on facility design and a two-vault stacking \\
\hline RHOS & $\begin{array}{l}\text { Bulk density of source } \\
\text { zone }\end{array}$ & $1.82 \mathrm{~g} / \mathrm{m}^{3}$ & $\begin{array}{l}\text { Based on the high permeability alluvium (DOE-ID } \\
\text { 2010) (ICDF performance assessment) }\end{array}$ \\
\hline \multicolumn{4}{|c|}{ Card 8c (Source) } \\
\hline THETAS & $\begin{array}{l}\text { Moisture content of } \\
\text { source }\end{array}$ & $\begin{array}{c}0.0989 \\
\mathrm{~cm}^{3} / \mathrm{cm}^{3}\end{array}$ & $\begin{array}{l}\text { Based on } 10-\mathrm{cm} / \text { year infiltration and hydraulic } \\
\text { properties of high-permeability alluvium (DOE-ID } \\
2010 \text { ) }\end{array}$ \\
\hline
\end{tabular}


Table 2. (continued).

\begin{tabular}{|c|c|c|c|}
\hline $\begin{array}{l}\text { GWSCREEN } \\
\text { Variable }\end{array}$ & Parameter Description & Value & Comments \\
\hline \multicolumn{4}{|c|}{ Card 9 (Unsaturated Zone) } \\
\hline DEPTH & $\begin{array}{l}\text { Depth from base of } \\
\text { source to top of aquifer } \\
\text { for Site } 5\end{array}$ & $20 \mathrm{~m}$ & Site-specific value \\
\hline DEPTH & $\begin{array}{l}\text { Depth from base of } \\
\text { source to top of aquifer } \\
\text { for Site } 34\end{array}$ & $16 \mathrm{~m}$ & $\begin{array}{l}\text { Site-specific value based on interbed thickness } \\
\text { underlying the ICDF (DOE-ID 2010) }\end{array}$ \\
\hline RHOU & $\begin{array}{l}\text { Bulk density-unsaturated } \\
\text { zone for Site } 5\end{array}$ & $1.5 \mathrm{~g} / \mathrm{cm}^{3}$ & Site-specific value \\
\hline RHOU & $\begin{array}{l}\text { Bulk density-unsaturated } \\
\text { zone for Site } 34\end{array}$ & $1.34 \mathrm{~g} / \mathrm{cm}^{3}$ & $\begin{array}{l}\text { Site-specific value for high-permeability interbeds } \\
\text { (DOE-ID 2010) }\end{array}$ \\
\hline AUX & $\begin{array}{l}\text { Longitudinal dispersivity } \\
\text { - unsaturated zone }\end{array}$ & $0 \mathrm{~m}$ & $\begin{array}{l}\text { Assumed plug flow through unsaturated zone for } \\
\text { both sites }\end{array}$ \\
\hline \multicolumn{4}{|c|}{ Card 9a (Unsaturated Zone) } \\
\hline THETAU & $\begin{array}{l}\text { Volumetric moisture } \\
\text { content of unsaturated } \\
\text { zone for Site } 5\end{array}$ & $\begin{array}{c}0.359 \\
\mathrm{~cm}^{3} / \mathrm{cm}^{3}\end{array}$ & $\begin{array}{l}\text { Site-specific value based on moisture characteristic } \\
\text { curves developed from data in well } \\
\text { ICPP-SCI-V-213 }\end{array}$ \\
\hline THETAU & $\begin{array}{l}\text { Volumetric moisture } \\
\text { content of unsaturated } \\
\text { zone for Site } 34\end{array}$ & $\begin{array}{l}0.0979 \\
\mathrm{~cm}^{3} / \mathrm{cm}^{3}\end{array}$ & $\begin{array}{l}\text { Site-specific value for high permeability interbeds } \\
\text { (DOE-ID 2010) and } 10-\mathrm{cm} / \text { year infiltration }\end{array}$ \\
\hline \multicolumn{4}{|c|}{ Card 10 (Aquifer) } \\
\hline $\mathrm{AX}$ & Longitudinal dispersivity & $9 \mathrm{~m}$ & DOE-ID (1994, p. C-11) \\
\hline AY & Transverse dispersivity & $4 \mathrm{~m}$ & DOE-ID (1994, p. C-11) \\
\hline $\mathrm{AZ}$ & Vertical dispersivity & NA & $\begin{array}{l}\text { Assumed two-dimensional, vertically averaged } \\
\text { model per Track } 2 \text { guidance; radionuclides are } \\
\text { mixed vertically in an aquifer that is as thick as the } \\
\text { well screen (DOE-ID 1994, p. C-11). }\end{array}$ \\
\hline Z & Well screen thickness & $15 \mathrm{~m}$ & DOE-ID $(1994$, p. C-11) \\
\hline \multicolumn{4}{|c|}{ Card 11 (Aquifer) } \\
\hline $\mathrm{U}$ & $\begin{array}{l}\text { Darcy velocity in aquifer } \\
\text { for Site } 5\end{array}$ & $21.0 \mathrm{~m} /$ year & Site-specific value \\
\hline $\mathrm{U}$ & $\begin{array}{l}\text { Darcy velocity in aquifer } \\
\text { for Site } 34\end{array}$ & $21.9 \mathrm{~m} /$ year & Site-specific value (DOE-ID 2010) \\
\hline PHI & Porosity of aquifer & $0.06 \mathrm{~cm}^{3} / \mathrm{cm}^{3}$ & Porosity of fractured basalt \\
\hline RHOA & Bulk density of aquifer & $1.9 \mathrm{~g} / \mathrm{cm}^{3}$ & DOE-ID $(1994$, p. C-11) \\
\hline \multicolumn{4}{|c|}{ Card 12b (Output) } \\
\hline XREC(I) & $\begin{array}{l}\text { Receptor distance } \\
\text { parallel to groundwater } \\
\text { flow (measured from } \\
\text { center of source) }\end{array}$ & $5 \mathrm{~m}$ & $\begin{array}{l}\text { One-half the length of source (AL/2), which is } \\
\text { immediately downgradient of the facility }\end{array}$ \\
\hline
\end{tabular}


Table 2. (continued).

\begin{tabular}{|c|c|c|c|}
\hline $\begin{array}{c}\text { GWSCREEN } \\
\text { Variable }\end{array}$ & Parameter Description & Value & Comments \\
\hline YREC(I) & $\begin{array}{l}\text { Receptor distance } \\
\text { perpendicular to } \\
\text { groundwater flow } \\
\text { (measured from center of } \\
\text { source) }\end{array}$ & $0 \mathrm{~m}$ & $\begin{array}{l}\text { Receptor located along flow path through center of } \\
\text { source }\end{array}$ \\
\hline Card 5 (Dose) & & & \\
\hline WI & $\begin{array}{l}\text { Water intake rate for } \\
\text { receptor }\end{array}$ & $2 \mathrm{~L} / \mathrm{d}$ & Track 2 default (DOE-ID 1994, p. C-8) \\
\hline $\mathrm{EF}$ & Exposure frequency & $365 \mathrm{~d} /$ year & Assume continuous exposure \\
\hline ED & Exposure duration & 1 year & $\begin{array}{l}\text { If exposure duration is set at } 1 \text { year or less, then } \\
\text { GWSCREEN will use the maximum dose for } \\
\text { calculating results }\end{array}$ \\
\hline
\end{tabular}




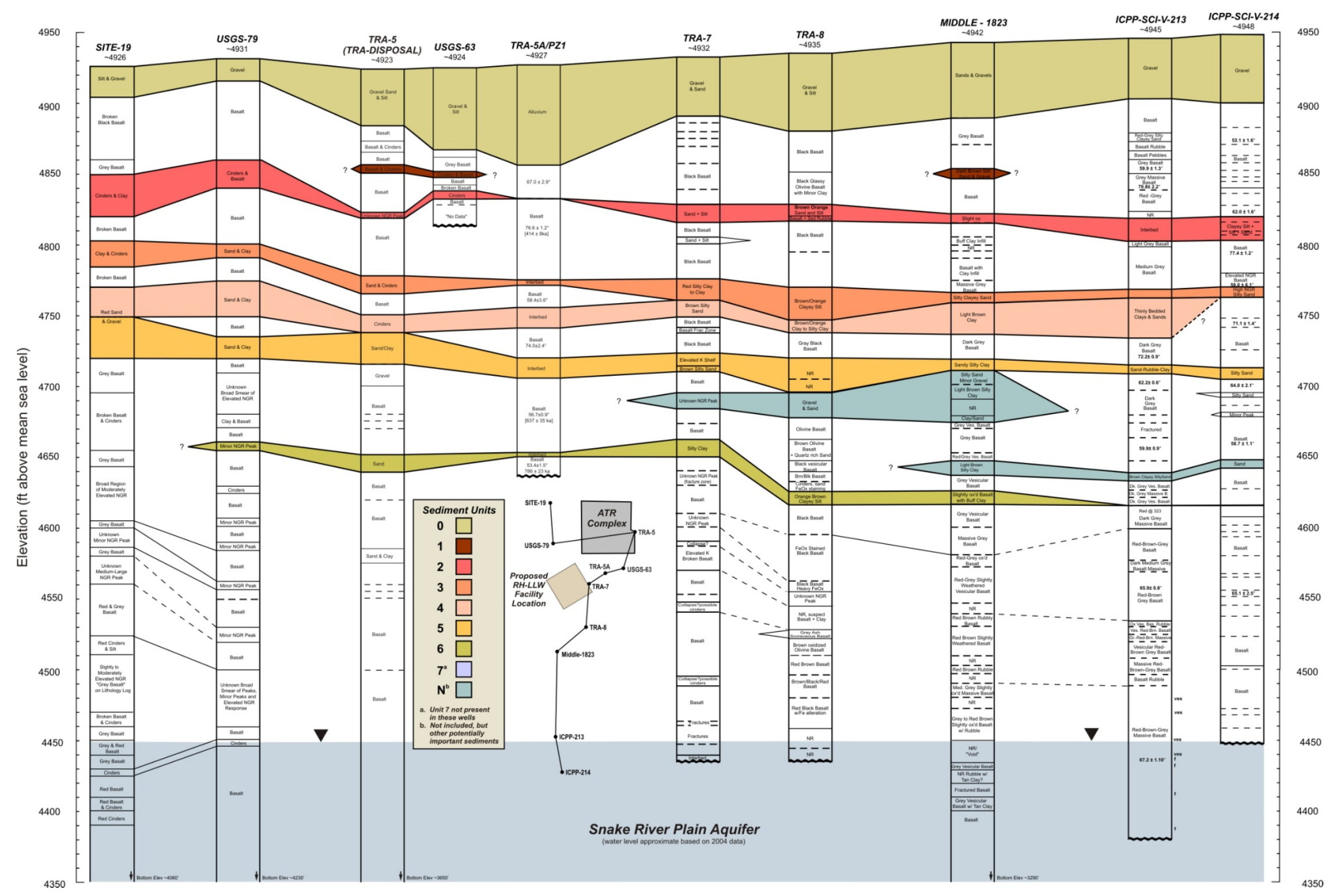

Figure 6. Geologic cross-section showing sedimentary interbed elevations and thicknesses near Site 5 southeast of the Advanced Test Reactor Complex (from INL 2010b). 


\section{A T R - C}

\section{SITE-190}

5

USGS-79 O

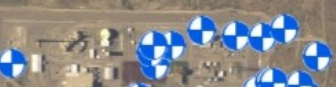

iil $\operatorname{lig}^{2}, 40$

III) ARA-5

$=0.400$

$\rightarrow$
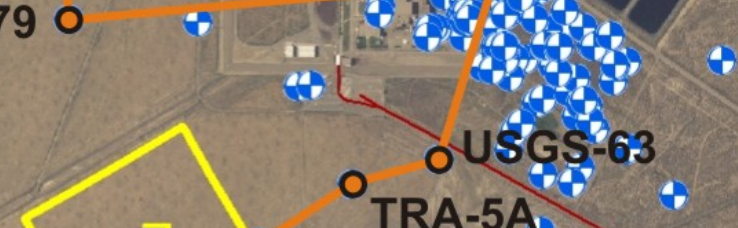

5 O TRA-5A STRA:07

$\checkmark$
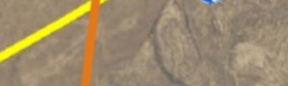

\section{TRA-08}

\section{4}

\section{MIDDLE-1823}

ICPP-SCI-V-213
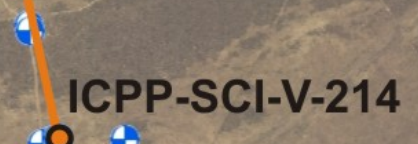

$\rightarrow$

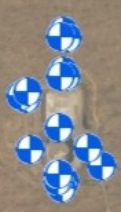

Figure 7. Location of the geologic cross-section near Site 5 shown in Figure 6. 


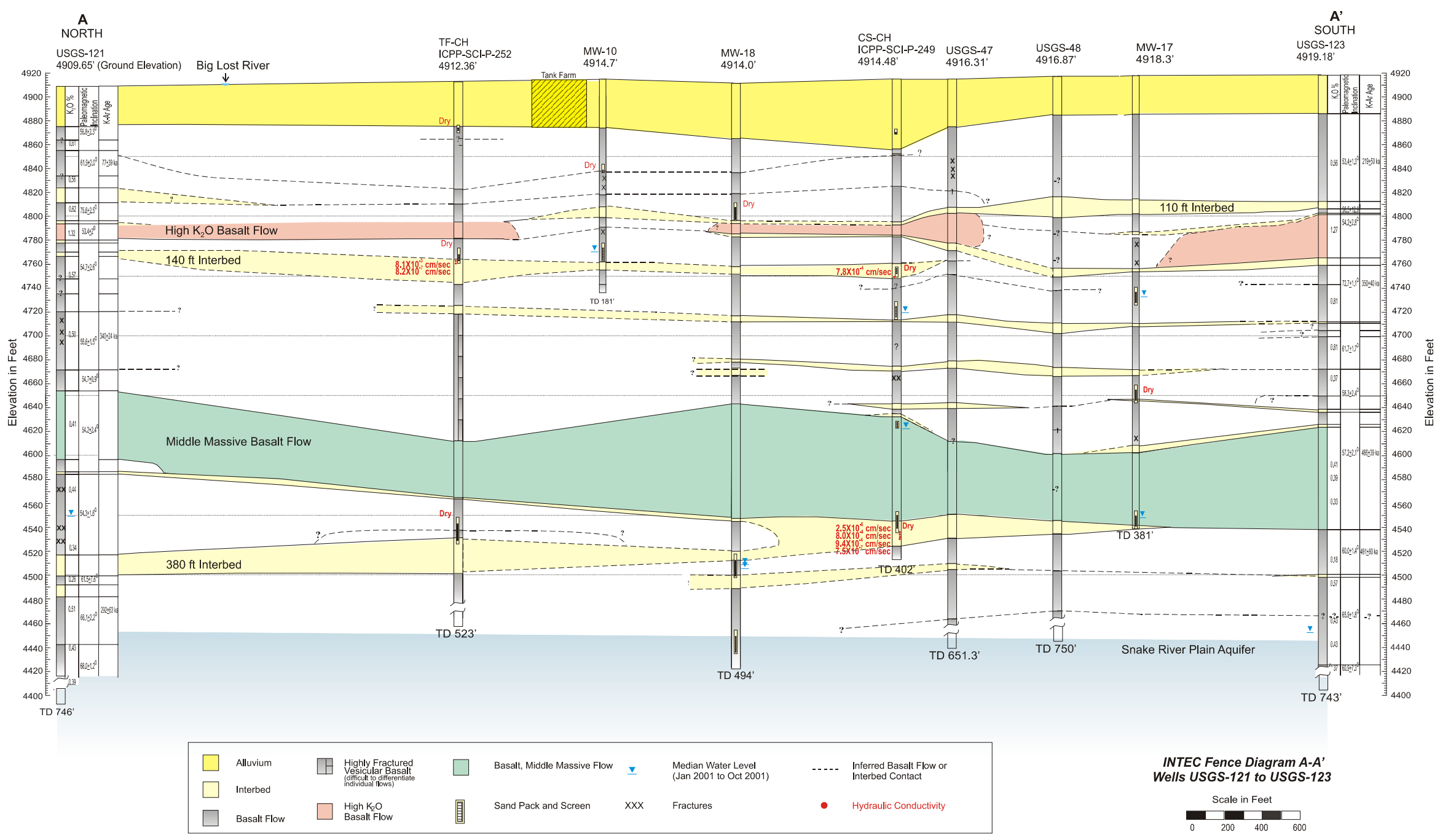

Figure 8. North-south geologic cross-section (A-A') at the Idaho Nuclear Technology and Engineering Center near Site 34 (from DOE-ID 2010). 


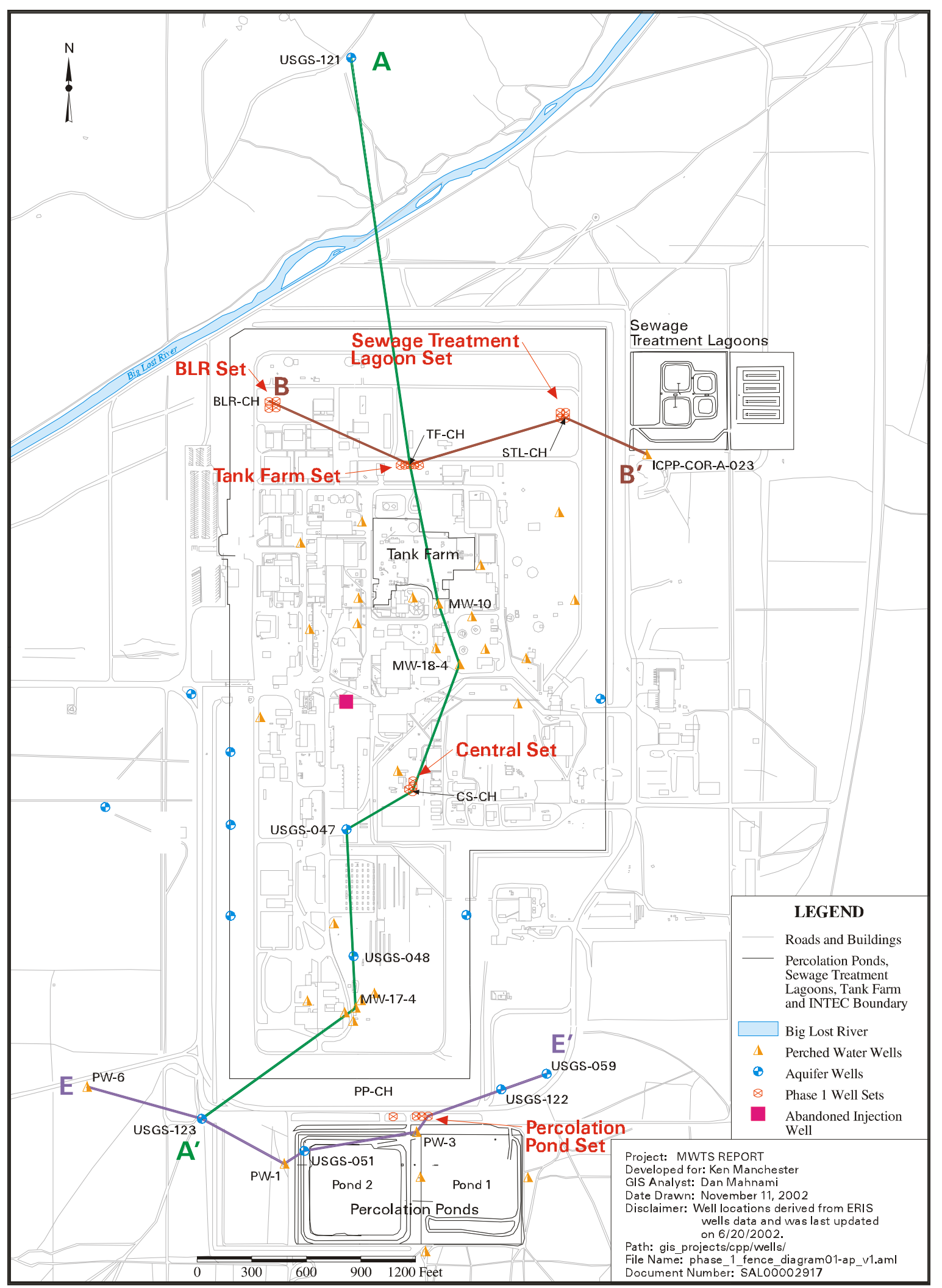

Figure 9. Location of the north-south geologic cross-section (A-A') at the Idaho Nuclear Technology and Engineering Center shown in Figure 8 (from DOE-ID 2010). 


\subsection{Phase IV: Detailed Source Release with Site-Specific Transport}

The primary differences between Phase III and Phase IV are that Phase IV includes waste-formspecific release mechanisms and rates, the functionality of the engineered barrier as it relates to reducing infiltration, site-specific $K_{d}$ in the alluvial base layer and sedimentary interbeds, and the inclusion of vadose zone and vertical aquifer dispersion. The relative sedimentary interbed abundance and other textural properties remain the same, as does aquifer velocity.

For Phase IV, the conceptual model of one-dimensional unsaturated and saturated zone has been implemented using the mixing cell model (MCM; Rood 2005). MCM allows detailed representation of surface wash from contaminated debris, dissolution or corrosion of activated metals accompanied by the release of radionuclides, and desorption of radionuclides from resins. Increasing the realism of releases from the waste zone requires parameterization of the sorption properties within and under the waste zone separately from those applied in the sedimentary interbeds and alluvium. Once released from the waste zone, it is assumed that transport occurs through the vadose zone under gravity-dominated, unit-gradient, and steady-state flow conditions. However, in addition to the assumptions and model parameters considered in Phase III, one-dimensional longitudinal dispersion is included in the vadose zone. Once in the aquifer, radionuclides are transported via advection and three-dimensional dispersion. As in Phase III, concentrations are vertically averaged over a well screen thickness of $15 \mathrm{~m}$, but the receptor is placed $100 \mathrm{~m}$ from the downgradient edge of the RH-LLW disposal facility, which is consistent with the approach required under DOE Order 435.1.

The basis for the MCM model is described in Rood (2005). The MCM model is essentially a first-order approximation to the second-order advection-dispersion equation and is similar in form to the Environmental Protection Agency assessment model SESOIL (Scott and Hetrick 1994). The conceptual model defines the unsaturated subsurface environment as a series of individual mixing cells (Figure 10). Within each mixing cell, the moisture content (fraction of the mixing cell volume composed of water) and contaminant concentration are uniform and assumed to equilibrate instantaneously in response to a change in the amount of water or contaminant entering the cell. Each mixing cell may have its own unique properties that include vertical dimensions, bulk density, hydraulic characteristics (e.g., porosity, residual moisture content, and hydraulic conductivity), and sorptive properties. Water balance within each cell is maintained by the difference between inflow and outflow. The water flux or specific discharge entering the uppermost mixing cell $(\mathrm{q})$ is assumed to be the net infiltration rate past the root zone. The net infiltration rate may change with time and, in turn, affect the specific discharge through all remaining cells below it. Water movement is assumed to be downward and under unit gradient conditions within a mixing cell. Specific discharge is assumed to be less than the saturated hydraulic conductivity of any of the materials comprising the vadose zone.

The conceptual model for contaminant transport considers two processes: advection and dispersion. Advective processes ( $\mathrm{F}$ in Figure 10) move the contaminant downward while dispersive processes (D in Figure 10) can move the contaminant upward or downward, depending on the concentration gradient between two adjacent cells. Dispersion results in greater spreading of the contaminant among the mixing cells. As shown later, dispersion effects can be simulated through implicit dispersion inherent in a MCM or may be simulated by including interchange between adjacent mixing cells.

Contaminant degradation is assumed to be a first-order process described by a half-life. The contaminant may degrade into one or more degradation products, each formed from the preceding product, and thereby forming a chain of degradation products such as in a radionuclide decay chain.

Contaminants entering a cell mix, sorb, decay, and are eventually removed by the downward movement of water. Contaminants sorb onto the solid matrix as described by the soil-to-water partition coefficient or $\mathrm{K}_{\mathrm{d}}$. Sorption retards the overall downward movement of contaminants. The rate of transport of the degradation products that form during vertical transport are governed by the sorptive properties of the degradation product, and not those of the originating contaminant. 


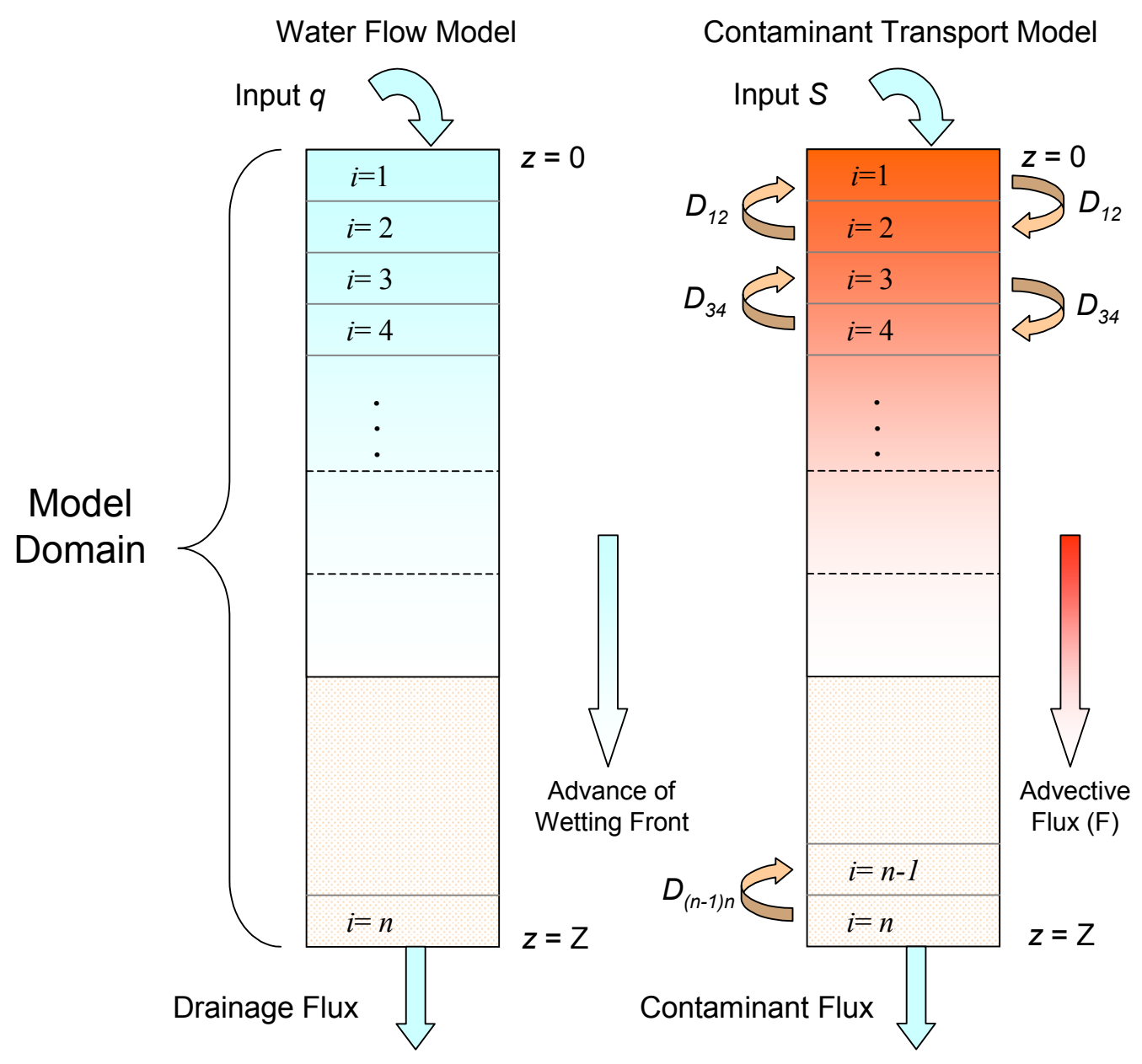

Figure 10. The mixing cell conceptual model for water flow (left) and contaminant transport (right). The model domain is discretized into $n$ cells and extends to a depth of $z=Z$. Interchange between cells is indicated by the variable $\mathrm{Di}, \mathrm{j}$ where $\mathrm{i}$ is the index of the donor cell and $\mathrm{j}$ is the index of the receiving cell.

As formulated, contaminants may be present in one or more of the mixing cells at the start of the simulation (as done for the low-mobility radionuclides in this analysis), or alternatively, the contaminant may be placed over time through an external source ( $\mathrm{S}$ in Figure 10) (as done for the high-mobility radionuclides in this analysis). Concentrations of contaminants in pore water are not allowed to exceed their element or compound-specific solubility limit.

\subsubsection{Flow and Transport Processes}

4.4.1.1 Mixing Cell Model Water Flow. A one-dimensional water-balance model coupled with material-specific moisture characteristic curves are used to calculate the net water flux through each MCM mixing cell, assuming unit gradient conditions exist throughout each cell. Additionally, water is assumed to be incompressible, its density remains constant, vapor-phase flow is inconsequential, and hydrostatic conditions are assumed to never exist (i.e., a net water flux of zero). The unit gradient model assumes water infiltration in the soil column is downward and driven by gravitational forces only. Mathematically, the specific discharge (i.e., Darcy velocity or Darcy flux) through a one-dimensional, vertically aligned, unsaturated soil column is described by:

$q=-K\left(\frac{\partial H}{\partial z}+\frac{\partial \psi}{\partial z}\right)$ 
where

$\mathrm{q} \quad=$ specific discharge $(\mathrm{L} / \mathrm{T})$

$\theta \quad=$ volumetric moisture content $\left(\mathrm{L}^{3} / \mathrm{L}^{3}\right)$

$\mathrm{H} \quad=$ elevation head (L)

$\psi \quad=$ suction or pressure head from capillary forces (L)

$\mathrm{K}=$ unsaturated hydraulic conductivity of the column $(\mathrm{L} / \mathrm{T})$

$\mathrm{Z} \quad=$ distance positive downward from the top of the column (L).

Under unit gradient conditions $\frac{\partial \psi}{\partial z}=0$ and $\frac{\partial H}{\partial z}=1$. Therefore, $\mathrm{q}=\mathrm{K}$, provided $\mathrm{q}$ is less than the saturated hydraulic conductivity. That is, the amount of water discharged from a mixing cell is equal to the unsaturated hydraulic conductivity at a given volumetric moisture content. The volumetric moisture content is the fraction of the bulk media that is filled with water. When a porous media is saturated (i.e., all the pore spaces are filled with water), the volumetric moisture content is equal to the effective porosity of the media. In this model, we have assumed the effective porosity is equal to the total porosity. Unit gradient conditions are assumed to exist at all times within a mixing cell. That is, once water enters the mixing cell, it is instantaneously and uniformly distributed within the mixing cell. Capillary forces are explicitly excluded from the model by assuming unit gradient conditions exist at all times. However, as shown in Rood (2005), these forces are implicitly accounted for through model discretization. Each cell is treated as an independent unit that may receive water from a cell above it and discharge water to the cell beneath it.

The continuity equation (assuming constant water density) states that change in the water stored in a unit volume of soil must equal the difference between the flux into and out of the unit volume and is given by:

$\frac{\partial \theta}{\partial t}=-\frac{\partial q}{\partial z}$.

Combining Equations 12 and 13 with the unit gradient assumptions gives the traditional formulation for one-dimensional unsaturated flow in a porous medium known as Richard's equation:

$\frac{\partial \theta}{\partial t}=\frac{\partial}{\partial z}\left(K \frac{\partial \psi}{\partial z}-K\right)$.

The unsaturated hydraulic conductivity is a function of the moisture content and described by the moisture characteristic curve. Combining Equations 12 and 13, with the assumption of unit gradient conditions (i.e., $\frac{\partial \psi}{\partial z}=0$ ) gives:

$\frac{\partial \theta}{\partial t}=-\frac{\partial}{\partial z} K(\theta)$.

The term, $\partial \mathrm{K}(\theta) / \partial \mathrm{z}$ is approximated for the MCM by:

$\frac{\partial \theta_{i}}{\partial t}=\frac{\mathrm{K}_{\mathrm{i}-1}\left(\theta_{\mathrm{i}-1}\right)-\mathrm{K}_{\mathrm{i}-1}\left(\theta_{\mathrm{i}-1}\right)}{\mathrm{Z}_{\mathrm{i}}-\mathrm{Z}_{\mathrm{i}-1}}$

where $i$ is the cell index number and zi is the depth of cell $i$ below a datum at index $i=0, z=0$. The water storage in the ith mixing cell ( $\phi i)$ is given by:

$\phi_{i}=\theta_{i} T_{i}$

where $T_{i}$ is the thickness of the $i^{t h}$ mixing cell, which is equivalent to $z_{i}-z_{i-1}$. Equation 16 is now rewritten in terms of the change in water storage with respect to time and given by: 
$\frac{d \phi_{i}}{d t} \frac{1}{T_{i}}=\frac{K_{i-1}\left(\theta_{i-1}\right)-K_{i}\left(\theta_{i}\right)}{T_{i}}$
$\frac{d \phi_{i}}{d t}=K_{i-1}\left(\theta_{i-1}\right)-K_{i}\left(\theta_{i}\right)$

For the uppermost mixing cell $(\mathrm{i}=1), \mathrm{K}_{\mathrm{i}-1}\left(\theta_{\mathrm{i}-1}\right)=\mathrm{K}_{0}\left(\theta_{0}\right)=\mathrm{q}(\mathrm{t})$ where $\mathrm{q}(\mathrm{t})$ is the net infiltration rate as a function of time into the uppermost mixing cell. Note that volumetric flow rates are achieved by multiplying Equation 18 by the horizontal surface area of the cells.

The functional relationship between the unsaturated hydraulic conductivity and moisture content is made using established empirical relationships that relate suction head to volumetric moisture content and unsaturated hydraulic conductivity. The relationship between these three parameters is referred to hereafter as the moisture characteristic curve. For this model, the unsaturated hydraulic conductivity as a function of moisture content as described by van Genuchten (1980) was used and is given by:

$\mathrm{K}(\theta)=\mathrm{K}_{\mathrm{sat}}\left(\frac{\theta-\theta_{\mathrm{r}}}{\theta_{\mathrm{s}}-\theta_{\mathrm{r}}}\right)^{\mathrm{L}}\left\{1-\left[1-\left(\frac{\theta-\theta_{\mathrm{r}}}{\theta_{\mathrm{s}}-\theta_{\mathrm{r}}}\right)^{\frac{1}{\mathrm{~m}}}\right]^{\mathrm{m}}\right\}^{2}$

And

$\frac{\theta-\theta_{\mathrm{r}}}{\theta_{\mathrm{s}}-\theta_{\mathrm{r}}}=\left[\frac{1}{1+(\alpha \psi)^{\mathrm{n}}}\right]^{\mathrm{m}} \quad\left(\theta_{\mathrm{r}} \leq \theta \leq \theta_{\mathrm{s}}\right)$

Where

$\theta \quad=\quad$ volumetric moisture content $\left(\mathrm{L}^{3} \mathrm{~L}^{-3}\right)$

$\theta \mathrm{r} \quad=$ residual moisture content $\left(\mathrm{L}^{3} \mathrm{~L}^{-3}\right)$

$\theta \mathrm{s}=$ saturated moisture content $\left(\mathrm{L}^{3} \mathrm{~L}^{-3}\right)$

Ksat $=$ saturated hydraulic conductivity $\left(\mathrm{L} \mathrm{T}^{-1}\right)$

$\psi \quad=\quad$ soil water matric suction pressure $(\mathrm{L})$

$\alpha=$ empirical fitting parameter $\left(\mathrm{L}^{-1}\right)$

$n=$ empirical fitting parameter

$m=1-1 / n$

$L=$ Mualem fitting parameter.

The moisture characteristic equations are valid when $\mathrm{q}<$ Ksat. Hydraulic properties that consider hysteresis were not included in this formulation. The moisture content in the ith mixing cell is used in combination with the moisture characteristic curve to determine $\mathrm{K}_{\mathrm{i}}\left(\theta_{\mathrm{i}}\right)$, the specific discharge through the ith mixing cell. The value of $\mathrm{K}_{\mathrm{i}}\left(\theta_{\mathrm{i}}\right)$ as a function of time is then passed to the transport model.

4.4.1.2 Mixing Cell Model Transport. The model for solute transport explicitly treats advective processes and implicitly or explicitly treats dispersive processes. The model is based on the onedimensional partial differential equation for mass transport in a variably saturated porous medium. The general transport equation for a single contaminant with first-order decay is given by (Codell et al. 1983):

$\mathrm{R}_{\mathrm{D}} \mathrm{A} \theta \frac{\partial \mathrm{C}}{\partial \mathrm{t}}=\mathrm{A} \frac{\partial}{\partial \mathrm{z}}\left(\theta \mathrm{D} \frac{\partial \mathrm{C}}{\partial \mathrm{z}}\right)-\mathrm{A} \frac{\partial \mathrm{qC}}{\partial \mathrm{z}}-\left(\mathrm{R}_{\mathrm{D}} \theta \lambda+\mathrm{R}_{\mathrm{D}} \frac{\partial \theta}{\partial \mathrm{t}}\right) \mathrm{AC}$

where

$A=$ across sectional area perpendicular to flow $\left(\mathrm{L}^{2}\right)$
$\mathrm{C}=$ concentration $\left(\mathrm{M} / \mathrm{L}^{3}\right)$ 


$$
\begin{aligned}
& \mathrm{RD}=\text { retardation } \\
& \mathrm{q}=\text { specific discharge or Darcy velocity }(\mathrm{L} / \mathrm{T}) \\
& \mathrm{D}=\text { dispersion coefficient }(\mathrm{L} 2 / \mathrm{T}) \\
& \mathrm{t}=\text { time }(\mathrm{T}) \\
& \lambda \quad=\text { first-order decay constant }(1 / \mathrm{T}) \\
& \mathrm{Z} \quad=\text { distance traversed parallel to direction of flow }(\mathrm{m}) .
\end{aligned}
$$

The mixing cell approximation is written in terms of the mass balance around fully mixed volume elements. Assuming unidirectional flow in the positive $\mathrm{z}$ direction, the MCM formulation for interior cells (i.e., $i \neq 1$ and $i \neq n$ where $n$ is the number of cells) of equal thickness, $T$ is given by:

$T_{i} R_{D} A \theta_{i} \frac{d C_{i}}{d t}=A \sum_{k} \frac{D_{i k}}{T_{i k}}\left(\theta_{k} C_{k}-\theta_{i} C_{i}\right)+A\left(q_{i-1} C_{i-1}\right)-A\left(q_{i} C_{i}\right)-T_{i} A R_{D} \theta_{i} \lambda C_{i}+S_{i}$

where $i$ is the cell index, $k$ is the index for cells adjacent cell $i$ (i.e., $i-1$ and $i+1$ ), $D_{i k}$ is the dispersion coefficient between cell $i$ and $k\left(\mathrm{~L}^{2} \mathrm{~T}^{-1}\right), T_{i k}$ is the distance separating the center of cell $i$ and $k(\mathrm{~L})$, and $S_{i}$ is an external source to cell $i\left(\mathrm{M} \mathrm{T}^{-1}\right)$. The first term in Equation 22 represents dispersion, the second and third terms represent advection, and the last term represents decay. The variables, $\theta$ and $q$, can be time-variable or constant depending on whether transient infiltration or steady-state flow is considered.

The term, $R_{D} \partial \theta / \partial t$ in Equation 21, enforces continuity between the moisture content and solute concentration. This term is zero under steady-state flow conditions. Continuity between the two quantities $(\theta$ and $C$ ) under transient flow conditions is achieved by determining the time-dependent moisture content at each time step. Moisture content as a function of time is calculated in the water flow portion of the code. The concentration in each cell at a given time-step is adjusted for the moisture content by:

$C_{i}^{m}=\frac{Q_{i}^{m}}{Q_{i}^{m} A T\left[1+\frac{K_{D i} \rho_{i}}{\theta_{i}^{m}}\right]}$

where

$C_{i}^{m}=$ contaminant pore water concentration in cell $\mathrm{i}$ at time-step $\mathrm{m}\left(\mathrm{M} \mathrm{L}^{-3}\right)$

$Q_{i}^{m}=$ mass of contaminant in cell $\mathrm{i}$ at time step $\mathrm{m}(\mathrm{M})$

$\mathrm{K}_{\mathrm{Di}}=$ equilibrium partition coefficient for mixing cell $\mathrm{i}\left(\mathrm{L} 3 \mathrm{M}^{-1}\right)$

$\rho_{\mathrm{i}} \quad=$ bulk density of mixing cell $\mathrm{i}\left(\mathrm{M} \mathrm{L}^{-3}\right)$

$\theta_{i}^{m}=$ the moisture content in mixing cell $\mathrm{i}$ at time step $\mathrm{m}\left(\mathrm{M} \mathrm{L}^{-3}\right)$.

The term, $1+\mathrm{K}_{\mathrm{Di}} \rho_{\mathrm{i}} / \theta_{\mathrm{i}}$ is the retardation coefficient and is unity for a $\mathrm{K}_{\mathrm{d}}$ of zero. Darcy fluxes in each cell and at each time step are calculated using the time-dependent value of $\theta$ and the material-specific moisture characteristic curve. If $\mathrm{C}_{\mathrm{i}}$, as given by Equation 23, exceeds the solubility limit, then $\mathrm{C}_{\mathrm{i}}=\mathrm{C}_{\mathrm{SI}}$ where $\mathrm{C}_{\mathrm{Sl}}$ is the solubility limit of the contaminant. The solubility adjustment does not affect the total mass of contaminant in the cell. The left-hand side of Equation 22 and the decay terms can now be rewritten in terms of the state variable (contaminant mass) by substituting the right hand side of Equation 23 for $\mathrm{C}$ :

$\frac{d Q_{i}}{d t}=A \frac{\sum_{k} D_{i k}}{T_{i k}}\left(\theta_{k} C_{k}-\theta_{i} C_{i}\right)+A\left(q_{i-1} C_{i-1}\right)-A\left(q_{i} C_{i}\right)-\lambda Q_{i}+S_{i}$

where $\mathrm{Q}_{\mathrm{i}}$ is the contaminant mass in the cell $i$. Equation 24 is valid for all nonboundary cells. Imposing the following boundary conditions: 
$D \frac{d C}{d z}=0 \quad$ at $\quad \mathrm{z}=0 \quad$ and $\quad \mathrm{z}=\mathrm{Z}$

gives the mass balance equations for the first $(i=1)$ and last $(i=n)$ cell in the system:

$\begin{array}{ll}\frac{d Q_{1}}{d t}=A \frac{D_{12}}{T_{12}}\left(\theta_{2} C_{2}-\theta_{1} C_{1}\right)+A\left(q_{1} C_{1}\right)-\lambda Q_{1}+S_{1} & \text { for } i=1 \\ \frac{d Q_{n}}{d t}=A \frac{D_{n-1, n}}{T_{1 n-1, n}}\left(\theta_{n-1} C_{n-1}-\theta_{n} C_{n}\right)+A\left(q_{n} C_{n}\right)-A\left(q_{n-1} C_{n-1}\right)-\lambda Q_{n}+S_{n} & \text { for } i=n\end{array}$.

Implementation of Equation 24 in the MCM code is performed differently than what is presented in Rood (2005). A simple procedure is used where each cell is treated as an independent unit and advective

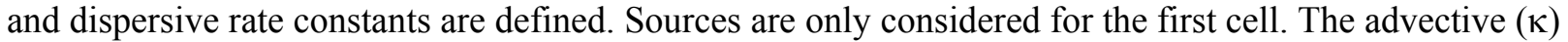
and dispersion $(\delta)$ rate constants are defined as follows:

$\kappa_{i}=\frac{q}{T_{i} \theta_{\mathrm{i}} \mathrm{R}_{\mathrm{D}_{\mathrm{i}}}} \quad$ and $\quad \delta_{i}=\frac{D_{i}}{T_{i}^{2}}$.

The advective rate constant is equivalent to the leach rate constant as described in Baes and Sharp (1983). An optional rate constant (designated kx) also is introduced into the governing equations that describes the transfer from cell $i$ to cell $i+1$. This rate constant is provided by the user and is calculated external to the code. Assigning rate constants to the advection, dispersive, and optional transfer processes, and expanding the summation term results in the following equation for interior cells:

$\begin{aligned} \frac{d Q_{i}}{d t}=A & \left.A \delta_{i-1} C_{i-1} \theta_{i-1} T_{i-1}+\delta_{i+1} C_{i+1} \theta_{i+1} T_{i+1}-2 \delta_{i} C_{i} \theta_{i} T_{i}\right] \\ & +\left(k x_{i-1}+\kappa_{i-1}\right) Q_{i-1}-\left(k x_{i}+\kappa_{i}\right) Q_{i}-\lambda Q_{i}\end{aligned}$

and

$\begin{array}{ll}\frac{d Q_{1}}{d t}=A\left[\delta_{2} C_{2} \theta_{2} T_{2}-\delta_{1} C_{1} \theta_{1} T_{1}\right]-\left(k x_{1}+\kappa_{1}\right) Q_{1}-\lambda Q_{1}+S_{1} & \text { for } i=1 \\ \frac{d Q_{n}}{d t}=A\left[\delta_{n-1} C_{n-1} \theta_{n-1} T_{n-1}-\delta_{n} C_{n} \theta_{n} T_{n}\right]+\left(k x_{n-1}+\kappa_{n-1}\right) Q_{n-1}-\left(k x_{n}+\kappa_{n}\right) Q_{n}-\lambda Q_{n} & \text { for } i=n\end{array}$

for the boundary cells. Equation 28 can now be expanded to include the transport of multiple decay products:

$$
\begin{aligned}
\frac{d Q_{i, j}}{d t}= & A\left[\delta_{i-1, j} C_{i-1, j} \theta_{i-1} T_{i-1}+\delta_{i+1, j} C_{i+1, j} \theta_{i+1} T_{i+1}-2 \delta_{i, j} C_{i, j} \theta_{i} T_{i}\right] \\
& +\left(k x_{i-1, j}+\kappa_{i-1, j}\right) Q_{i-1, j}-\left(k x_{i, j}+\kappa_{i, j}\right) Q_{i, j}-\lambda_{j} Q_{i, j}+B R_{j} \lambda_{j-1} Q_{i, j-1}
\end{aligned}
$$

where, $j$ is the index for the decay chain member, $\mathrm{BR}_{\mathrm{j}}$ is the fraction of decay product $j-1$ that decays to product $j$, and $k x_{i j}$ is the optional rate constant describing transfer from cell $i$ to cell $i+1$ for contaminant $j$. For the originating contaminant in a series of degradation products, the term, $\mathrm{BR}_{\mathrm{j}} \lambda_{\mathrm{j}-1} \mathrm{Q}_{\mathrm{i}, \mathrm{j}-1}$ is omitted from Equation 30. The decay rate constant is given by Equation 31:

$\lambda_{j}=\frac{\ln (2)}{t_{1 / 2}}$

where $t_{1 / 2}$ is the half-life of contaminant $j$. Equation 30 describes the MCM with interchange. Equation 30 also gives the MCM without interchange, except the dispersive terms are omitted (i.e., $\delta=0$ ). The MCM without interchange is useful because relatively simple analytical solutions exist for the equations describing the system. These solutions are useful for simple conceptual models and model verification exercises.

The overall objective of the model is to provide a solute flux to the aquifer. The solute flux to the aquifer for degradation product $j$ at $z=Z(i=n)$ for the stated boundary conditions is given by: 
$F_{j}=A\left(q_{n} C_{n, j}\right)=\frac{q_{n} Q_{n, j}}{\theta_{n} T_{n} R_{D_{n, j}}}$

where $F_{j}$ is the solute flux to the aquifer from cell $n$ for decay product $j$.

4.4.1.3 Mixing Cell Model Discretization and Solute Dispersion. The dispersive behavior of the MCM is similar to that of the advection dispersion equation and is related to the physical dispersion of the system (Zvirin and Shinnar 1976; Van Ommen 1985; Appelo and Willemsen 1987; Shanahan and Harleman 1984). Shanahan and Harleman (1984) use the term implicit dispersion to describe the dispersion that is inherent in the formulation of mass transport around fully mixed volume elements (cells) and described in terms of ordinary differential equations. The dimensionless Peclet number characterizes dispersion and is given by:

$P e=\frac{Z q}{D \theta}$

where $P e$ is the Peclet number, $Z$ is the length of the vadose zone $(L)$, and $D$ is the dispersion coefficient $\left(L^{2} T^{-1}\right)$. The dispersion coefficient is given by:

$D=\frac{\alpha_{L} q}{\theta}+D_{m}$

where $D_{m}$ is the effective molecular diffusion coefficient, and $\alpha_{L}$ is the longitudinal dispersivity.

Molecular diffusion may be important for systems with extremely low specific discharge. Equation 33 is referred to here as the scale-length Peclet number because it is the ratio of advection to dispersion for the entire system. If molecular diffusion is neglected, Equation 33 reduces to $P e=Z / \alpha_{L}$.

Levenspiel and Bischoff (1963) established a relationship between the number of equal thickness mixing cells and the scale-length Peclet number for the mixing cell-model without interchange. They concluded that the number of mixing cells is approximately related to the Peclet number as given by:

$\frac{1}{N}=\frac{2}{P e^{2}}\left(P e-1+e^{P e}\right)$

which can be approximated by Shanahan and Harleman (1984)

$N=\frac{P e+1}{2}$

or as $n$ becomes large

$N \cong \frac{P e}{2}$.

Zvirin and Shinnar (1976) as reported in Shanahan and Harleman (1984) defined the relationship between an equivalent Peclet number $(\mathrm{Pe})$ and $n$ for the MCM with interchange as

$P e=\frac{2 N}{1+2 \beta}$

where $\beta$ is the ratio of the exchange flow to through-flow and all cells are of equal size. The influence of cell interchange is to decrease the Peclet number (increase dispersion) by the factor $1+2 \beta$. Shanahan and Harleman (1984) define exchange flow as $D A / T$ and through-flow as $A q / \theta$, where $T$ is the distance separating adjacent mixing cells. If molecular diffusion is neglected, $\beta$ can be written in terms of the local dispersivity:

$\beta=\frac{D A}{A q / \theta T}=\frac{\alpha_{L^{*}} q \theta}{T q \theta}=\frac{\alpha_{L^{*}}}{T}$.

The term $\beta$ is essentially the inverse of the local (or grid) Peclet number. The term $\alpha_{L^{*}}$ represents the equivalent local dispersivity accounting for implicit dispersion. If the dispersivity of the overall system is $\alpha_{L}$, then the equivalent local dispersivity can be derived from Equations 33, 38, and 39: 
$\alpha_{L^{*}}=\left[\frac{2 N \alpha_{L}}{Z}-1\right] \frac{T}{2}$.

It can be shown that as $n \rightarrow \infty, \alpha_{L^{*}} \rightarrow \alpha_{\mathrm{L}}$. If $\alpha_{\mathrm{L}^{*}}$ is negative, then implicit dispersion is greater than the dispersion defined by $\alpha_{\mathrm{L}}$ and additional cells must be added. For the case where molecular diffusion is not negligible, an equivalent local dispersion coefficient $\left(D^{*}\right)$ is calculated for each cell and given by Equation 41:

$D^{*}=\left[\frac{2 D_{i}}{q_{i} / \theta_{i}}-1\right] \frac{T q_{i} / \theta_{i}}{2}$.

MCM calculates the movement of each radioactive progeny separately according to the progeny's element-specific $\mathrm{K}_{\mathrm{d}}$ (see Equation 30).

\subsubsection{Phase IV Model Parameterization}

In order to parameterize MCM, including the processes ongoing in the vault system, release mechanisms and rates from the initial waste form were first incorporated. The next level of complexity is introduced by the geochemical environment of the cement-steel-container system. Fresh cement increases the $\mathrm{pH}$ relative to natural infiltration water, creating a local geochemical environment that dictates radionuclide-specific $\mathrm{K}_{\mathrm{d}} \mathrm{s}$ for cement-sand mixes. The geochemistry of the vault system also impacts the alluvial base layer underlying the vault system, altering the sorption behavior of alluvial materials. It is assumed that the near-field geochemical environment will revert back to natural conditions as infiltrating water not passing through the facility mixes with waters transported through the vault system. This assumption is conservative because it results in the use of lower $\mathrm{K}_{d} \mathrm{~s}$ in the sedimentary interbeds than would be used if the higher $\mathrm{pH}$ environment were assumed to persist to depth.

The discretization used to represent the vault system, alluvial base layer, and basalt-sediment sequence at Site 5 is shown in Figure 11. At Site 5, the alluvial base layer is represented by $5 \mathrm{~m}$ of alluvial material as determined by the total alluvial thickness south of the ATR Complex (INL 2010b). The total sediment thickness is $20 \mathrm{~m}$ and depth to the aquifer is approximately $140 \mathrm{~m}$. Surficial sediment near Site 34 is represented by the values determined for the nearby ICDF facility and are much thinner as represented in Figure 12 (where $2 \mathrm{~m}$ of alluvial base layer are represented). The total sedimentary interbed thickness shown in Figure 12 for Site 34 is $16 \mathrm{~m}$. Depth to the aquifer at INTEC is roughly equal to that at the ATR Complex. At both sites, the vault system is represented by $6 \mathrm{~m}$ of porous media.

4.4.2.1 Release Mechanisms and Release Rates. As the containers fail, the radionuclides are assumed to be released from their original waste form over time by either surface wash or dissolution. Surface wash generally leads to the most conservative releases because releases are assumed to occur instantaneously as water contacts the waste. This allows the entire inventory of radionuclides to be exposed to infiltrating water. The surface wash model applies a partition coefficient to determine the rate of release by maintaining the radionuclide concentration in water in proportion to $\mathrm{K}_{\mathrm{d}}$. The solid fraction considered to reside in the vault system is comprised of cement and sand. This mechanism is assumed for the debris and resin waste forms.

Dissolution is used to represent releases that occur as activated metals break down over time. Activation products are often integral to the base metal and are assumed to be released by dissolution as the metal corrodes. The most conservative corrosion rates at INL were provided by Nagata and Banaee (1996) where a stainless steel corrosion rate of $1 \mathrm{~mm}$ in 4,500 years $(2.22 \mathrm{E}-05 \mathrm{~cm} /$ year $)$ was determined. This value represented the corrosion rate for immersion tests conducted at INTEC, where stainless coupons were subjected to a magnesium chloride solution at a 6-m burial depth temperature and oxygen content. The magnesium chloride solution was used to represent the long-term use of a dust suppressant at RWMC. Review of additional data provided a surface-area-to-volume ratio for typical INL-type reactor components equal to $0.535 / \mathrm{cm}$ (Oztunali and Roles 1985). Combining the corrosion rate and geometry 
data provides a fractional release from stainless steel of 1.19E-05/year in the soil where the dust suppressant had been applied.

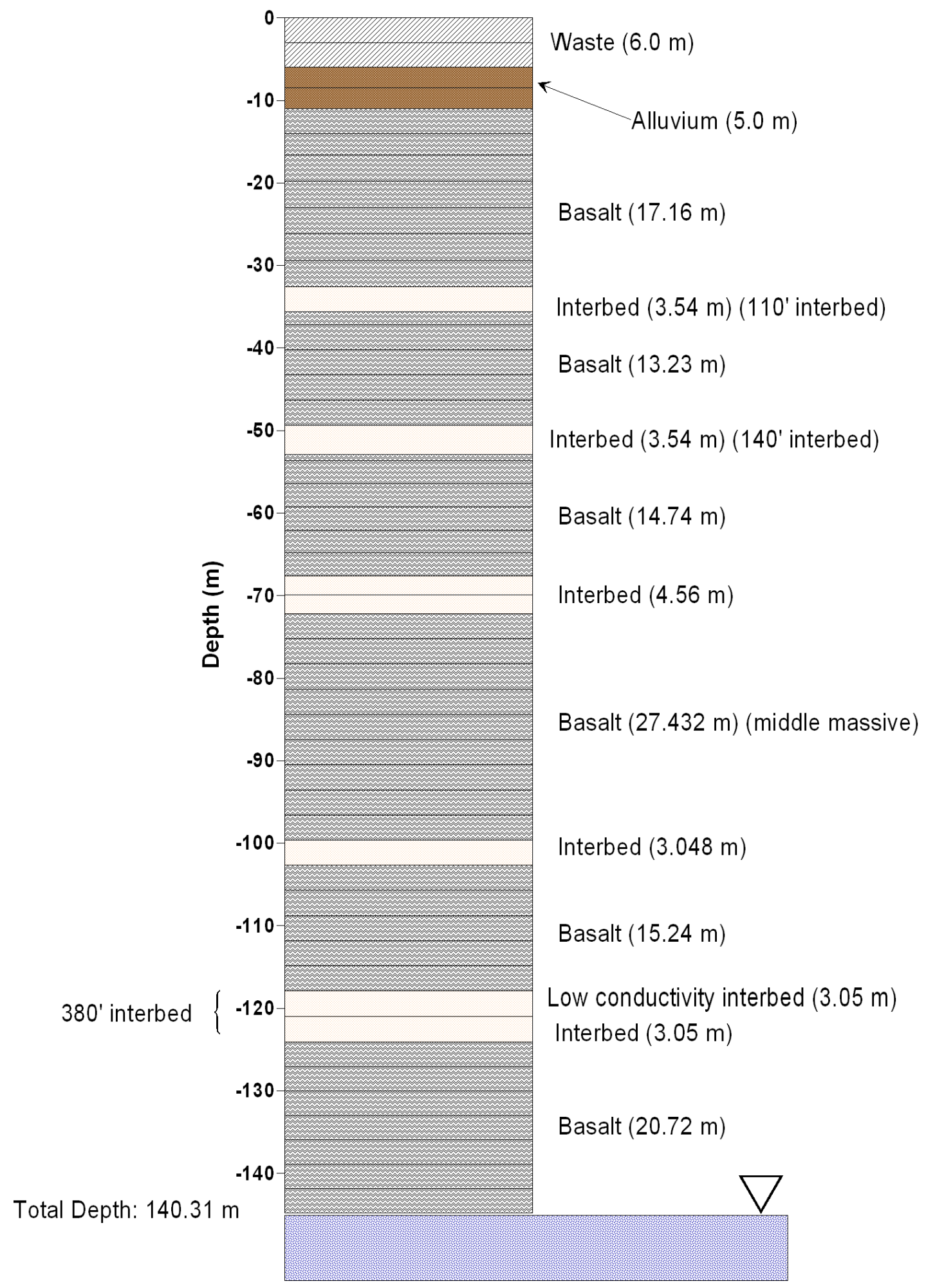

Figure 11. Discretization of the cement-sand-vault system, alluvial base layer, basalt, and sedimentary interbeds used to represent the subsurface at Site 5 (near ATR Complex). 




Figure 12. Discretization of the cement-sand-vault system, alluvial base layer, basalt, and sedimentary interbeds used to represent the subsurface at Site 34 (near INTEC). 
The chloride in the dust suppressant increases the corrosion rate relative to what would occur under natural soil conditions as shown by Adler-Flitton et al. (2004). Based on direct testing of coupons buried

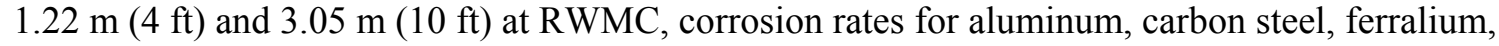
zircaloy-4, inconel, 304L and 316L stainless steel, and 316L welded stainless steel were obtained after 1 year, 3 years, and 6 years of burial. Corrosion rates decreased with burial depth and with time of burial for all reported results. The 6-year average corrosion rates, assuming $0.535-\mathrm{cm}$ surface area to volume ratios for their reported results, are given in Table 3. In all cases, the fractional release rate observed by Adler-Flitton et al. (2004) is less than that derived from Nagata and Banaee (1996).

Table 3. Corrosion rates and fractional release rates for buried metals in Idaho National Laboratory soils.

\begin{tabular}{lcrr}
\multicolumn{1}{c}{ Metal } & \multicolumn{2}{c}{ Corrosion Rate } & \multicolumn{2}{c}{$\begin{array}{c}\text { Fractional } \\
\text { Release } \\
\text { year }^{-1}\end{array}$} \\
\hline Aluminum & mils/year & $\mathrm{cm} /$ year & $8.83 \mathrm{E}-7$ \\
Carbon steel & $6.50 \mathrm{E}-4$ & $1.65 \mathrm{E}-7$ & $4.64 \mathrm{E}-4$ \\
$\begin{array}{l}\text { Stainless steel: 304L, 316L, 315L } \\
\text { welded }\end{array}$ & $3.42 \mathrm{E}-1$ & $8.68 \mathrm{E}-4$ & $1.36 \mathrm{E}-7$ \\
Inconel and ferralium & $1.0 \mathrm{E}-04$ & $2.54 \mathrm{E}-7$ & $1.36 \mathrm{E}-7$ \\
\hline
\end{tabular}

The same source release models will be adopted for both candidate sites. The surface wash model will be represented in MCM as a 10-m $\times 120$-m soil-radionuclide mixture $6 \mathrm{~m}$ deep containing the debris and resin source inventories. The activated metals will be represented as an influx of radionuclides with the rate equal to the inventory of each radionuclide in activated metal times the fractional release rate from stainless steel. A fractional release rate of 1.19E-05/year was used in the Phase IV screening analysis (DOE-ID 2007a). It is conservative for all metal types expected to be deposited in the proposed RH-LLW disposal facility. At both sites, the facility is assumed to be oriented with the long-axis perpendicular to the aquifer flow direction.

4.4.2.2 Infiltration Rate. As implied above, during the operational period, infiltration into the facility will not contact the waste emplaced in the steel liners and concrete vaults. After capping the facility, infiltration through the waste zone will be small by design. In Phase III the infiltration rate was assumed to be $10 \mathrm{~cm} /$ year. In Phase IV, an infiltration rate of $1 \mathrm{~cm} /$ year, which is equal to the estimated background infiltration rate for undisturbed soils (Cecil et al. 1992) will be used. This is still larger than the $0.1 \mathrm{~cm} /$ year rate calculated by Mattson et al. (2004) for a proposed cover for the RWMC.

4.4.2.3 Sorption Characteristics. $\mathrm{K}_{d} \mathrm{~s}$ have been estimated for the radionuclides carried forward from the Phase III screening step. Table 4 contains estimated $\mathrm{K}_{\mathrm{d}}$ values for fresh and mature cement in oxic and reducing conditions for the Phase IV radionuclides. Although the fresh cement with oxic conditions is most likely representative of the 1,000-year compliance period for the facility, the mature cement values are more conservative for some of the nuclides of interest.

The sedimentary interbeds underlying the ATR Complex and INTEC contain varying amounts of gravel, sand, silt, and clay. Interbeds at INTEC are generally characterized as sandy silts, with percentages of clay, silt, sand, and gravel equal to $15.7,44.5,27.7$, and $12.1 \%$, respectively (DOE-ID 2003b). Sediment comprising the interbeds at Site 5 contains more clay content and very little gravel. Percentages of clay, silt, sand and gravel at Site 5 are 22.9, 38.6, 37.7 and $0.8 \%$, respectively (Doornbos et al. 1991). 
Table 4. Distribution coefficients (mL/g) for the cement-sand vault environment (from INL 2010c).

\begin{tabular}{lrrrr}
\hline & \multicolumn{3}{c}{ Mature Cement } \\
\cline { 2 - 5 } Radionuclide & Oxic Conditions & Reducing Conditions & Oxic Conditions & Reducing Conditions \\
\hline C-14 & 500 & 500 & 100 & 100 \\
H-3 & & & & \\
I-129 & 10 & 10 & 5 & 5 \\
Ni-59 & 100 & 100 & 100 & 100 \\
Tc-99 & 0 & 1,000 & 0 & 1,000 \\
U-238 & 1,000 & 2,000 & 1,000 & 2,000 \\
\hline
\end{tabular}

Blank indicates value has not been determined for this nuclide.

Using $\mathrm{K}_{\mathrm{d}}$ values for sand, loam, and clay (Sheppard and Thibault, 1990) and a $\mathrm{K}_{\mathrm{d}}$ of 0 for gravel, a weighted average $K_{d}$ value was computed using the fractional textural characteristics for both Site 5 and 34 using the following formula:

$\mathrm{K}_{\mathrm{d}_{\text {weighted }}}=\mathrm{f}_{\text {gravel }} \mathrm{K}_{\text {Dgravel }}+\mathrm{f}_{\text {sand }} \mathrm{K}_{\mathrm{D}_{\text {sand }}}+\mathrm{f}_{\text {silt }} \mathrm{K}_{\mathrm{D}_{\text {silt }}}+\mathrm{f}_{\text {clay }} \mathrm{K}_{\mathrm{D}_{\text {clay }}}$

where $f_{\text {sand }}, f_{\text {silt }}$, and $f_{\text {clay }}$ is the fraction of sand, silt, and clay, respectively. In this case, the value for loam was applied to the silt fraction. The Sheppard and Thibault (1990) and resulting site-specific $\mathrm{K}_{\mathrm{d}} \mathrm{s}$ are shown in Table 5, Columns 6 and 7. Columns 8 and 9 contain the values for alluvium and sedimentary interbed for the INTEC Operable Unit 3-14 investigation (DOE-ID 2006a). These values, relative to the texture-derived $\mathrm{K}_{d} \mathrm{~S}$ are very conservative and primarily represent a sand-loam mix without the higher sorptive clay fraction.

$\mathrm{K}_{\mathrm{d}} \mathrm{S}$ were selected for use in the Phase IV screening based, in part, on previously used conservative values, Track 2 guidance for radionuclides not previously evaluated (DOE-ID 1994), and conservative ranges of cement-affected alluvial base layer material. In this case, the alluvial base layer includes the compacted sand/gravel and any additional sediment above the first basalt layer. $\mathrm{K}_{\mathrm{d}} \mathrm{S}$ were assumed to be equal for both sites based on the similar computed $K_{d}$ values shown in Table 5 for Site 5 and Site 34 . Sorption in the top $6 \mathrm{~m}$ of the waste zone (Figures 11 and 12) was neglected, as was sorption in the basalts. It was assumed that the downward migration of cement-affected water would impact the alluvial base layer, and conservative values (i.e. mature cement, oxic conditions) were selected from Table 4 to represent that unit. Interbed values were the same as those used for Phase III except for C-14 and I-129 which used values from DOE-ID (2006a). The resultant $\mathrm{K}_{\mathrm{d}}$ values used in the Phase IV analysis are presented in Table 6.

4.4.2.4 Dispersivity. Dispersivity used in the Phase IV analysis was taken from the ICDF performance assessment (DOE 2010a). The vertical dispersivity in the vadose zone was $1.44 \mathrm{~m}$ based on the implicit dispersion in the MCM model (see Equations 35 through 37). Three-dimensional dispersivity in the aquifer was assigned values of $3.31 \mathrm{~m}, 0.662 \mathrm{~m}$, and $0.00384 \mathrm{~m}$ in the longitudinal, transverse, and vertical directions, respectively. These values were used to represent dispersion at both sites.

4.4.2.5 Other Model Parameters. Other model parameters were the same as applied in the Phase III screening step (shown in Table 2), with the exception of the hydraulic moisture characteristic properties and the receptor distance in the aquifer. Van Genuchten parameters were used with a Mualem model to represent data at both sites. These values are shown in Tables 7 and 8 for Site 5 and Site 34, respectively. At both sites, high-permeability alluvium representative of INTEC alluvium was used for the cement-vault system and the alluvial base layer. Low and high-permeability interbeds have been 
characterized at INTEC through the CERCLA investigations (DOE-ID 2006a) and are represented by the values shown in Table 8. Properties for Site 5 interbeds were determined by the U.S. Geological Survey for well ICPP-SCI-V-213 (DOE-ID 2003c; DOE-ID 2005; Wood et al. 2007; DOE-ID 2008). Unsaturated basalt properties were documented in Wood et al. (2007).

The receptor in the aquifer was placed $100 \mathrm{~m}$ downgradient from the downgradient edge of the facility as specified in DOE Order 435.1.

Table 5. Distribution coefficients ( $\mathrm{mL} / \mathrm{g}$ ) for gravel, sand, loam (silt), and clay from Sheppard and Thibault (1990), with computed values for Sites 34 and 5, based on soil texture and values used in the Operable Unit 3-14 remedial investigation/baseline risk assessment (DOE-ID 2006a).

\begin{tabular}{lrrrrrrrr}
\hline Radionuclide & $\begin{array}{c}\text { Gravel } \\
\mathrm{K}_{\mathrm{d}}\end{array}$ & $\begin{array}{c}\text { Sand } \\
\mathrm{K}_{\mathrm{d}}\end{array}$ & $\begin{array}{c}\text { Loam } \\
\mathrm{K}_{\mathrm{d}}\end{array}$ & $\begin{array}{c}\text { Clay } \\
\mathrm{K}_{\mathrm{d}}\end{array}$ & $\begin{array}{c}\text { Site } 34 \\
\mathrm{~K}_{\mathrm{d}}\end{array}$ & $\begin{array}{c}\text { Site 5 } \\
\mathrm{K}_{\mathrm{d}}\end{array}$ & $\begin{array}{c}\text { Operable Unit 3-14 } \\
\text { Alluvium } \mathrm{K}_{\mathrm{d}}\end{array}$ & $\begin{array}{c}\text { Operable Unit 3-14 } \\
\text { Interbed } \mathrm{K}_{\mathrm{d}}\end{array}$ \\
\hline C-14 & 0 & 5 & 20 & 1 & 10.44 & 9.83 & 1.6 & $\mathrm{~N}$ \\
H-3 & 0 & 0 & 0 & 0 & 0.00 & 0.00 & $\mathrm{NV}$ & $\mathrm{N}$ \\
$\mathrm{I}-129$ & 0 & 1 & 5 & 1 & 2.66 & 2.53 & 1.5 & $\mathrm{~N}$ \\
Ni-59 & 0 & 400 & 300 & 650 & 346.06 & 415.18 & 0.7 \\
Tc-99 & 0 & 0.1 & 0.1 & 1 & 0.23 & 0.31 & 0 & 0 \\
U-238 & 0 & 35 & 15 & 1,600 & 267.07 & 385.12 & 1.6 & 1.6 \\
\hline
\end{tabular}

$\mathrm{NV}=$ no value listed for this nuclide

Table 6. Distribution coefficients $(\mathrm{mL} / \mathrm{g})$ used in the Phase IV screening analysis. Distribution coefficients in the alluvial base layer are altered by concrete chemistry. Distribution coefficients in the waste are assumed to be zero, simulating surface wash from the waste. INTEC Alluvium values provided for comparison purposes.

\begin{tabular}{|c|c|c|c|c|c|c|}
\hline Element & Waste & $\begin{array}{c}\text { Alluvial } \\
\text { Base } \\
\text { Layer }\end{array}$ & $\begin{array}{l}\text { INTEC } \\
\text { Alluvium }^{\mathrm{a}} \\
\end{array}$ & Interbed & Basalt & References \\
\hline $\mathrm{C}$ & 0 & $100^{\mathrm{b}}$ & 1.6 & 1.6 & 0 & $\begin{array}{l}\text { Alluvial Base Layer (INL 2010c), Interbed } \\
\text { (DOE-ID 2006a) }\end{array}$ \\
\hline $\mathrm{H}$ & 0 & 0 & 0 & 0 & 0 & Alluvial Base Layer and Interbed (DOE-ID 1994) \\
\hline I & 0 & $5^{\mathrm{b}}$ & 1.5 & 0.7 & 0 & $\begin{array}{l}\text { Alluvial Base Layer (INL 2010c), Interbed } \\
\text { (DOE-ID 2006a) }\end{array}$ \\
\hline $\mathrm{Ni}$ & 0 & $100^{\mathrm{b}}$ & 100 & 100 & 0 & $\begin{array}{l}\text { Alluvial Base Layer (INL 2010c, DOE-ID 1994), } \\
\text { Interbed (DOE-ID 1994) }\end{array}$ \\
\hline Tc & 0 & $0^{\mathrm{b}}$ & 0 & 0 & 0 & $\begin{array}{l}\text { Alluvial Base Layer (INL 2010c, DOE-ID 1994), } \\
\text { Interbed (DOE-ID 1994) }\end{array}$ \\
\hline $\mathrm{U}$ & 0 & $1,000^{\mathrm{b}}$ & 1.6 & 1.6 & 0 & $\begin{array}{l}\text { Alluvial Base Layer (INL 2010c), Interbed } \\
\text { (DOE-ID 2006a) }\end{array}$ \\
\hline Th & 0 & 100 & 100 & 100 & 0 & Alluvial Base Layer and Interbed (DOE-ID 1994) \\
\hline $\mathrm{Ra}$ & 0 & 100 & 100 & 100 & 0 & Alluvial Base Layer and Interbed (DOE-ID 1994) \\
\hline $\mathrm{Pb}$ & 0 & 100 & 100 & 100 & 0 & Alluvial Base Layer and Interbed (DOE-ID 1994) \\
\hline
\end{tabular}

a. Values from OU 3-14 RI/BRA (DOE-ID 2006a).

b. Mature cement values from INL (2010c). 
Table 7. Hydraulic parameters used to represent flow at Site 5.

\begin{tabular}{|c|c|c|c|c|c|c|c|c|c|}
\hline Lithology & $\begin{array}{c}\text { Saturated } \\
\text { Hydraulic } \\
\text { Conductivity } \\
\text { (m/year) }\end{array}$ & $\begin{array}{c}\text { Total } \\
\text { Porosity }\end{array}$ & $\begin{array}{l}\text { Residual } \\
\text { Moisture } \\
\text { Content }\end{array}$ & $\begin{array}{c}\text { Van } \\
\text { Genuchten } \\
\text { Fitting } \\
\text { Parameter } \\
n \\
\end{array}$ & $\begin{array}{c}\text { Van } \\
\text { Genuchten } \\
\text { Fitting } \\
\text { Parameter } \\
\alpha(1 / \mathrm{m}) \\
\end{array}$ & $\begin{array}{c}\text { Van } \\
\text { Genuchten } \\
\text { Fitting } \\
\text { Parameter } \\
m \\
\end{array}$ & $\begin{array}{c}\text { Mualem } \\
\text { Fitting } \\
\text { Parameter } \\
L \\
\end{array}$ & $\begin{array}{c}\text { Bulk } \\
\text { Density } \\
\left(\mathrm{g} / \mathrm{cm}^{3}\right)\end{array}$ & Reference \\
\hline $\begin{array}{l}\text { High-permeability } \\
\text { alluvium and waste }\end{array}$ & 8,798 & 0.32 & 0.0002 & 1.4 & 100 & 0.29 & 0.5 & 1.82 & DOE-ID (2006a) \\
\hline Interbed & 1.258 & 0.459 & 0.165 & 1.4 & 0.052 & 0.83 & 9.25 & 1.5 & $\begin{array}{l}\text { Based on well } \\
\text { ICPP-SCI-V-213, } \\
\text { (DOE-ID 2003c; } \\
\text { DOE-ID 2005; } \\
\text { Wood et al. 2007; } \\
\text { DOE-ID 2008) } \\
\text { Bulk density } \\
\text { assumed }\end{array}$ \\
\hline Unsaturated basalt & 91 & 0.05 & 0.001 & 10 & 2.5 & 0.90 & 0.5 & 2 & Wood et al. (2007) \\
\hline
\end{tabular}

Table 8. Hydraulic parameters used to represent flow at Site 34.

\begin{tabular}{|c|c|c|c|c|c|c|c|c|c|}
\hline Lithology & $\begin{array}{c}\text { Saturated } \\
\text { Hydraulic } \\
\text { Conductivity } \\
\text { (m/year) }\end{array}$ & $\begin{array}{c}\text { Total } \\
\text { Porosity } \\
\end{array}$ & $\begin{array}{c}\text { Residual } \\
\text { Moisture } \\
\text { Content }\end{array}$ & $\begin{array}{c}\text { Van } \\
\text { Genuchten } \\
\text { Fitting } \\
\text { Parameter } \\
n \\
\end{array}$ & $\begin{array}{c}\text { Van } \\
\text { Genuchten } \\
\text { Fitting } \\
\text { Parameter } \\
\alpha(1 / \mathrm{m}) \\
\end{array}$ & $\begin{array}{c}\text { Van } \\
\text { Genuchten } \\
\text { Fitting } \\
\text { Parameter } \\
m \\
\end{array}$ & $\begin{array}{c}\text { Mualem } \\
\text { Fitting } \\
\text { Parameter } \\
L \\
\end{array}$ & $\begin{array}{c}\text { Bulk } \\
\text { Density } \\
\left(\mathrm{g} / \mathrm{cm}^{3}\right) \\
\end{array}$ & Reference \\
\hline $\begin{array}{l}\text { High-permeability } \\
\text { alluvium and waste }\end{array}$ & 8,798 & 0.32 & 0.0002 & 1.4 & 100 & 0.29 & 0.5 & 1.82 & DOE-ID (2006a) \\
\hline $\begin{array}{l}\text { High-permeability } \\
\text { interbed }\end{array}$ & 1,040 & 0.6 & 0.11 & 1.29 & 10.5 & 0.22 & 0.5 & 1.34 & DOE-ID (2006a) \\
\hline $\begin{array}{l}\text { Low-permeability } \\
\text { interbed }\end{array}$ & 0.76 & 0.49 & 0.0002 & 1.38 & 0.01 & 0.28 & 0.5 & 1.34 & DOE-ID (2006a) \\
\hline Unsaturated basalt & 91 & 0.05 & 0.001 & 10 & 2.5 & 0.90 & 0.5 & 2 & Wood et al. (2007) \\
\hline
\end{tabular}




\section{RESULTS}

Results of the four screening and analysis phases are discussed in the following subsections.

\subsection{Phase I Results}

Phase I removed 143 radionuclides with half-lives of 1-year or less from further consideration. In addition, 13 radionuclides with half lives greater than 1 year were removed because they have no dose conversion factor or MCL. These 13 radionuclides are mostly stable elements or noble gases. Therefore, a total of 156 radionuclides were removed from the inventory shown in Table 1 . The remaining 89 radionuclides were retained for Phase II consideration. These 89 radionuclides, with their inventory and half-lives, are shown in Table 9. These results are not site dependent and apply to both Site 5 and Site 34.

Table 9. Phase I screening results based on half-life.

\begin{tabular}{|c|c|c|c|c|c|}
\hline Radionuclide & $\begin{array}{l}\text { Inventory } \\
\text { (Ci) }\end{array}$ & $\begin{array}{l}\text { Half-Life } \\
\text { (years) }\end{array}$ & Radionuclide & $\begin{array}{l}\text { Inventory } \\
\text { (Ci) }\end{array}$ & $\begin{array}{c}\text { Half-Life } \\
\text { (years) }\end{array}$ \\
\hline Ac-227 & $1.77 \mathrm{E}-06$ & $2.18 \mathrm{E}+01$ & Os-194 & $3.58 \mathrm{E}-09$ & $6.00 \mathrm{E}+00$ \\
\hline Ag-108m & $2.80 \mathrm{E}-05$ & $1.27 \mathrm{E}+02$ & $\mathrm{~Pa}-231$ & $8.77 \mathrm{E}-06$ & $3.28 \mathrm{E}+04$ \\
\hline Am-241 & $7.63 \mathrm{E}-01$ & $4.32 \mathrm{E}+02$ & $\mathrm{~Pb}-205$ & $8.23 \mathrm{E}-07$ & $1.43 \mathrm{E}+07$ \\
\hline$A m-242 m$ & $2.11 \mathrm{E}-03$ & $1.52 \mathrm{E}+02$ & Pd-107 & 3.07E-04 & $6.50 \mathrm{E}+06$ \\
\hline Am-243 & $8.58 \mathrm{E}-04$ & $7.38 \mathrm{E}+03$ & Pm-145 & $1.62 \mathrm{E}-10$ & $1.77 \mathrm{E}+01$ \\
\hline Ba-133 & $1.90 \mathrm{E}-03$ & $1.07 \mathrm{E}+01$ & Pm-146 & $6.77 \mathrm{E}-08$ & $5.53 \mathrm{E}+00$ \\
\hline Be-10 & $1.53 \mathrm{E}-04$ & $1.60 \mathrm{E}+06$ & Pm-147 & $8.79 \mathrm{E}+03$ & $2.62 \mathrm{E}+00$ \\
\hline Bi-210m & $8.55 \mathrm{E}-07$ & $3.00 \mathrm{E}+06$ & Pt-193 & $8.74 \mathrm{E}-04$ & $5.00 \mathrm{E}+01$ \\
\hline C-14 & $4.12 \mathrm{E}+02$ & $5.73 \mathrm{E}+03$ & $\mathrm{Pu}-236$ & 5.92E-07 & $2.85 \mathrm{E}+00$ \\
\hline $\mathrm{Ca}-41$ & $1.36 \mathrm{E}-02$ & $1.40 \mathrm{E}+05$ & $\mathrm{Pu}-238$ & $1.21 \mathrm{E}+00$ & $8.77 \mathrm{E}+01$ \\
\hline Cd-109 & $3.05 \mathrm{E}-01$ & $1.27 \mathrm{E}+00$ & $\mathrm{Pu}-239$ & 4.10E-01 & $2.41 \mathrm{E}+04$ \\
\hline Cd-113m & $3.95 \mathrm{E}-02$ & $1.36 \mathrm{E}+01$ & $\mathrm{Pu}-240$ & $1.99 \mathrm{E}-01$ & $6.54 \mathrm{E}+03$ \\
\hline Cf-249 & $5.66 \mathrm{E}-12$ & $3.51 \mathrm{E}+02$ & $\mathrm{Pu}-241$ & $2.36 \mathrm{E}+01$ & $1.44 \mathrm{E}+01$ \\
\hline Cf-250 & $1.46 \mathrm{E}-10$ & $1.31 \mathrm{E}+01$ & $\mathrm{Pu}-242$ & $2.99 \mathrm{E}-04$ & $3.76 \mathrm{E}+05$ \\
\hline Cf-251 & $1.26 \mathrm{E}-13$ & $8.98 \mathrm{E}+02$ & Ra-226 & $5.22 \mathrm{E}-11$ & $1.60 \mathrm{E}+03$ \\
\hline $\mathrm{Cl}-36$ & $1.54 \mathrm{E}-01$ & $3.01 \mathrm{E}+05$ & Ra-228 & $2.60 \mathrm{E}-07$ & $5.75 \mathrm{E}+00$ \\
\hline $\mathrm{Cm}-243$ & $1.32 \mathrm{E}-03$ & $2.85 \mathrm{E}+01$ & $\mathrm{Rb}-87$ & $1.03 \mathrm{E}-06$ & $4.70 \mathrm{E}+10$ \\
\hline $\mathrm{Cm}-244$ & $8.66 \mathrm{E}-02$ & $1.81 \mathrm{E}+01$ & Re-187 & 8.94E-01 & $5.00 \mathrm{E}+10$ \\
\hline $\mathrm{Cm}-245$ & $1.36 \mathrm{E}-06$ & $8.50 \mathrm{E}+03$ & Rh-102 & $1.16 \mathrm{E}-04$ & $2.90 \mathrm{E}+00$ \\
\hline $\mathrm{Cm}-246$ & $1.03 \mathrm{E}-06$ & $4.73 \mathrm{E}+03$ & Ru-106 & $3.11 \mathrm{E}+03$ & $1.01 \mathrm{E}+00$ \\
\hline $\mathrm{Cm}-247$ & $1.89 \mathrm{E}-13$ & $1.56 \mathrm{E}+07$ & $\mathrm{Sb}-125$ & $2.96 \mathrm{E}+04$ & $2.77 \mathrm{E}+00$ \\
\hline Co-60 & $2.90 \mathrm{E}+06$ & $5.27 \mathrm{E}+00$ & Se-79 & 8.38E-03 & $6.50 \mathrm{E}+04$ \\
\hline Cs-134 & $3.59 \mathrm{E}+02$ & $2.06 \mathrm{E}+00$ & Si-32 & $6.68 \mathrm{E}-07$ & $4.50 \mathrm{E}+02$ \\
\hline Cs-135 & $1.54 \mathrm{E}-02$ & $2.30 \mathrm{E}+06$ & Sm-147 & $4.11 \mathrm{E}-10$ & $1.06 \mathrm{E}+11$ \\
\hline Cs-137 & $6.27 \mathrm{E}+03$ & $3.00 \mathrm{E}+01$ & Sm-151 & $4.86 \mathrm{E}+01$ & $9.00 \mathrm{E}+01$ \\
\hline
\end{tabular}


Table 9. (continued).

\begin{tabular}{lccccc}
\hline \multicolumn{1}{c}{ Radionuclide } & $\begin{array}{c}\text { Inventory } \\
(\text { Ci) }\end{array}$ & $\begin{array}{c}\text { Half-Life } \\
\text { (years) }\end{array}$ & Radionuclide & $\begin{array}{c}\text { Inventory } \\
\text { (Ci) }\end{array}$ & $\begin{array}{c}\text { Half-Life } \\
\text { (years) }\end{array}$ \\
\hline Eu-152 & $1.02 \mathrm{E}+01$ & $1.33 \mathrm{E}+01$ & Sn-121m & $1.23 \mathrm{E}+02$ & $5.50 \mathrm{E}+01$ \\
Eu-154 & $2.44 \mathrm{E}+02$ & $8.80 \mathrm{E}+00$ & Sn-126 & $1.50 \mathrm{E}-04$ & $1.00 \mathrm{E}+05$ \\
Eu-155 & $3.90 \mathrm{E}+02$ & $4.96 \mathrm{E}+00$ & Sr-90 & $6.18 \mathrm{E}+03$ & $2.91 \mathrm{E}+01$ \\
Fe-55 & $1.19 \mathrm{E}+06$ & $2.70 \mathrm{E}+00$ & Ta-180 & $6.97 \mathrm{E}-01$ & $1.00 \mathrm{E}+13$ \\
H-3 & $3.88 \mathrm{E}+03$ & $1.24 \mathrm{E}+01$ & Tc-99 & $1.67 \mathrm{E}+01$ & $2.13 \mathrm{E}+05$ \\
Hf-182 & $1.08 \mathrm{E}-04$ & $9.00 \mathrm{E}+06$ & Te-123 & $2.66 \mathrm{E}-09$ & $1.00 \mathrm{E}+13$ \\
Ho-166m & $5.10 \mathrm{E}-08$ & $1.20 \mathrm{E}+03$ & Th-228 & $2.98 \mathrm{E}-04$ & $1.91 \mathrm{E}+00$ \\
I-129 & $1.33 \mathrm{E}-01$ & $1.57 \mathrm{E}+07$ & Th-229 & $5.63 \mathrm{E}-08$ & $7.34 \mathrm{E}+03$ \\
In-115 & $4.91 \mathrm{E}-13$ & $5.10 \mathrm{E}+15$ & Th-230 & $5.30 \mathrm{E}-08$ & $7.70 \mathrm{E}+04$ \\
Ir-192m & $9.26 \mathrm{E}-06$ & $2.41 \mathrm{E}+02$ & Th-232 & $2.80 \mathrm{E}-07$ & $1.41 \mathrm{E}+10$ \\
K-40 & $1.26 \mathrm{E}-03$ & $1.28 \mathrm{E}+09$ & Tl-204 & $2.19 \mathrm{E}-22$ & $3.78 \mathrm{E}+00$ \\
La-137 & $1.96 \mathrm{E}-06$ & $6.00 \mathrm{E}+04$ & Tm-171 & $2.74 \mathrm{E}-07$ & $1.92 \mathrm{E}+00$ \\
Lu-176 & $1.45 \mathrm{E}-08$ & $3.60 \mathrm{E}+10$ & $\mathrm{U}-232$ & $3.63 \mathrm{E}-04$ & $7.20 \mathrm{E}+01$ \\
Mo-93 & $2.92 \mathrm{E}+01$ & $3.50 \mathrm{E}+03$ & U-233 & $1.19 \mathrm{E}-04$ & $1.59 \mathrm{E}+05$ \\
Nb-93m & $5.83 \mathrm{E}+02$ & $1.36 \mathrm{E}+01$ & U-234 & $1.08 \mathrm{E}-03$ & $2.45 \mathrm{E}+05$ \\
Nb-94 & $1.09 \mathrm{E}+02$ & $2.03 \mathrm{E}+04$ & $\mathrm{U}-235$ & $5.14 \mathrm{E}-03$ & $7.04 \mathrm{E}+08$ \\
Ni-59 & $3.27 \mathrm{E}+03$ & $7.50 \mathrm{E}+04$ & U-236 & $1.23 \mathrm{E}-04$ & $2.34 \mathrm{E}+07$ \\
Ni-63 & $3.98 \mathrm{E}+05$ & $9.60 \mathrm{E}+01$ & U-238 & $1.62 \mathrm{E}+01$ & $4.47 \mathrm{E}+09$ \\
Np-235 & $2.28 \mathrm{E}-09$ & $1.08 \mathrm{E}+00$ & Zr-93 & $4.03 \mathrm{E}+01$ & $1.53 \mathrm{E}+06$ \\
Np-237 & $2.99 \mathrm{E}-03$ & $2.14 \mathrm{E}+06$ & & & \\
\hline & & & & & \\
\hline
\end{tabular}

\subsection{Phase II Results}

Phase II applies the NCRP screening process to the 89 radionuclides contained in Table 9. In this step, 33 radionuclides with an NCRP screening dose less than 0.4-mrem/year EDE were removed from further consideration. Fifty-six radionuclides have an NCRP dose greater than 0.4-mrem/year EDE and were retained for Phase III consideration. The entire list of radionuclides has been sorted by the NCRP screening dose and is shown in Table 10. Retained radionuclides are indicated by a "Yes" in Column 5 of Table 10; those that are not retained are indicated by a "No." As with Phase I, this step is not site dependent and results apply to both Site 5 and Site 34.

Table 10. Phase II screening results using the National Council on Radiation Protection screening factors.

\begin{tabular}{lcccc}
\multicolumn{1}{c}{ Radionuclide } & $\begin{array}{c}\text { Inventory } \\
(\mathrm{Ci})\end{array}$ & $\begin{array}{c}\text { NCRP Screening Factor } \\
(\mathrm{mrem} / \mathrm{Ci})\end{array}$ & $\begin{array}{c}\text { NCRP Screening Dose } \\
\text { (mrem/year) }\end{array}$ & Retained \\
\hline Co-60 & $2.90 \mathrm{E}+06$ & $2.44 \mathrm{E}+04$ & $7.09 \mathrm{E}+10$ & Yes \\
$\mathrm{Sr}-90$ & $6.18 \mathrm{E}+03$ & $1.33 \mathrm{E}+05$ & $8.24 \mathrm{E}+08$ & Yes \\
Cs-137 & $6.27 \mathrm{E}+03$ & $5.18 \mathrm{E}+04$ & $3.25 \mathrm{E}+08$ & Yes \\
Ni-63 & $3.98 \mathrm{E}+05$ & $1.52 \mathrm{E}+02$ & $6.03 \mathrm{E}+07$ & Yes \\
\hline
\end{tabular}


Table 10. (continued).

\begin{tabular}{|c|c|c|c|c|}
\hline Radionuclide & $\begin{array}{l}\text { Inventory } \\
(\mathrm{Ci})\end{array}$ & $\begin{array}{l}\text { NCRP Screening Factor } \\
(\mathrm{mrem} / \mathrm{Ci})\end{array}$ & $\begin{array}{l}\text { NCRP Screening Dose } \\
\text { (mrem/year) }\end{array}$ & Retained \\
\hline $\mathrm{Sb}-125$ & $2.96 \mathrm{E}+04$ & $1.30 \mathrm{E}+03$ & $3.83 \mathrm{E}+07$ & Yes \\
\hline $\mathrm{C}-14$ & $4.12 \mathrm{E}+02$ & $6.29 \mathrm{E}+04$ & $2.59 \mathrm{E}+07$ & Yes \\
\hline $\mathrm{U}-238$ & $1.62 \mathrm{E}+01$ & $6.29 \mathrm{E}+05$ & $1.02 \mathrm{E}+07$ & Yes \\
\hline $\mathrm{Nb}-94$ & $1.09 \mathrm{E}+02$ & $6.29 \mathrm{E}+04$ & $6.87 \mathrm{E}+06$ & Yes \\
\hline Eu-154 & $2.44 \mathrm{E}+02$ & $2.00 \mathrm{E}+04$ & $4.88 \mathrm{E}+06$ & Yes \\
\hline $\mathrm{H}-3$ & $3.88 \mathrm{E}+03$ & $1.15 \mathrm{E}+03$ & $4.45 \mathrm{E}+06$ & Yes \\
\hline $\mathrm{Fe}-55$ & $1.19 \mathrm{E}+06$ & $3.66 \mathrm{E}+00$ & $4.34 \mathrm{E}+06$ & Yes \\
\hline Cs-134 & $3.59 \mathrm{E}+02$ & $3.70 \mathrm{E}+03$ & $1.33 \mathrm{E}+06$ & Yes \\
\hline Tc-99 & $1.67 \mathrm{E}+01$ & $4.81 \mathrm{E}+04$ & $8.05 \mathrm{E}+05$ & Yes \\
\hline Sn-121m & $1.23 \mathrm{E}+02$ & $3.70 \mathrm{E}+03$ & $4.56 \mathrm{E}+05$ & Yes \\
\hline Eu-152 & $1.02 \mathrm{E}+01$ & $2.44 \mathrm{E}+04$ & $2.50 \mathrm{E}+05$ & Yes \\
\hline Eu-155 & $3.90 \mathrm{E}+02$ & $6.29 \mathrm{E}+02$ & $2.46 \mathrm{E}+05$ & Yes \\
\hline $\mathrm{Ni}-59$ & $3.27 \mathrm{E}+03$ & $7.03 \mathrm{E}+01$ & $2.30 \mathrm{E}+05$ & Yes \\
\hline I- 129 & $1.33 \mathrm{E}-01$ & $7.40 \mathrm{E}+05$ & $9.87 \mathrm{E}+04$ & Yes \\
\hline Pm-147 & $8.79 \mathrm{E}+03$ & $6.29 \mathrm{E}+00$ & $5.53 \mathrm{E}+04$ & Yes \\
\hline $\mathrm{Cl}-36$ & $1.54 \mathrm{E}-01$ & $2.63 \mathrm{E}+05$ & $4.04 \mathrm{E}+04$ & Yes \\
\hline $\mathrm{Pu}-238$ & $1.21 \mathrm{E}+00$ & $2.92 \mathrm{E}+04$ & $3.55 \mathrm{E}+04$ & Yes \\
\hline Mo-93 & $2.92 \mathrm{E}+01$ & $9.62 \mathrm{E}+02$ & $2.81 \mathrm{E}+04$ & Yes \\
\hline $\mathrm{Nb}-93 \mathrm{~m}$ & $5.83 \mathrm{E}+02$ & $4.81 \mathrm{E}+01$ & $2.80 \mathrm{E}+04$ & Yes \\
\hline $\mathrm{Pu}-241$ & $2.36 \mathrm{E}+01$ & $1.07 \mathrm{E}+03$ & $2.53 \mathrm{E}+04$ & Yes \\
\hline Am-241 & 7.63E-01 & $3.11 \mathrm{E}+04$ & $2.37 \mathrm{E}+04$ & Yes \\
\hline Ta-180 & $6.97 \mathrm{E}-01$ & $2.78 \mathrm{E}+04$ & $1.93 \mathrm{E}+04$ & Yes \\
\hline $\mathrm{Pu}-239$ & $4.10 \mathrm{E}-01$ & $3.52 \mathrm{E}+04$ & $1.44 \mathrm{E}+04$ & Yes \\
\hline $\mathrm{Pu}-240$ & $1.99 \mathrm{E}-01$ & $3.48 \mathrm{E}+04$ & $6.93 \mathrm{E}+03$ & Yes \\
\hline Cd-113m & $3.95 \mathrm{E}-02$ & $1.15 \mathrm{E}+05$ & $4.53 \mathrm{E}+03$ & Yes \\
\hline Zr-93 & $4.03 \mathrm{E}+01$ & $9.62 \mathrm{E}+01$ & $3.88 \mathrm{E}+03$ & Yes \\
\hline Np-237 & $2.99 \mathrm{E}-03$ & $1.11 \mathrm{E}+06$ & $3.32 \mathrm{E}+03$ & Yes \\
\hline $\mathrm{Cm}-244$ & $8.66 \mathrm{E}-02$ & $1.11 \mathrm{E}+04$ & $9.61 \mathrm{E}+02$ & Yes \\
\hline Sm-151 & $4.86 \mathrm{E}+01$ & $1.11 \mathrm{E}+01$ & $5.39 \mathrm{E}+02$ & Yes \\
\hline$A m-242 m$ & $2.11 \mathrm{E}-03$ & $1.92 \mathrm{E}+05$ & $4.06 \mathrm{E}+02$ & Yes \\
\hline U-235 & $5.14 \mathrm{E}-03$ & $7.40 \mathrm{E}+04$ & $3.80 \mathrm{E}+02$ & Yes \\
\hline Cs- 135 & $1.54 \mathrm{E}-02$ & $6.29 \mathrm{E}+03$ & $9.70 \mathrm{E}+01$ & Yes \\
\hline $\mathrm{U}-232$ & 3.63E-04 & $2.48 \mathrm{E}+05$ & $8.99 \mathrm{E}+01$ & Yes \\
\hline $\mathrm{K}-40$ & $1.26 \mathrm{E}-03$ & $3.18 \mathrm{E}+04$ & $4.01 \mathrm{E}+01$ & Yes \\
\hline Am-243 & $8.58 \mathrm{E}-04$ & $4.07 \mathrm{E}+04$ & $3.49 \mathrm{E}+01$ & Yes \\
\hline
\end{tabular}


Table 10. (continued).

\begin{tabular}{|c|c|c|c|c|}
\hline Radionuclide & $\begin{array}{l}\text { Inventory } \\
(\mathrm{Ci})\end{array}$ & $\begin{array}{l}\text { NCRP Screening Factor } \\
(\mathrm{mrem} / \mathrm{Ci})\end{array}$ & $\begin{array}{l}\text { NCRP Screening Dose } \\
\text { (mrem/year) }\end{array}$ & Retained \\
\hline $\mathrm{Ca}-41$ & $1.36 \mathrm{E}-02$ & $2.37 \mathrm{E}+03$ & $3.21 \mathrm{E}+01$ & Yes \\
\hline Cd-109 & $3.05 \mathrm{E}-01$ & $1.04 \mathrm{E}+02$ & $3.16 \mathrm{E}+01$ & Yes \\
\hline $\mathrm{Cm}-243$ & $1.32 \mathrm{E}-03$ & $2.04 \mathrm{E}+04$ & $2.69 \mathrm{E}+01$ & Yes \\
\hline U-234 & $1.08 \mathrm{E}-03$ & $2.15 \mathrm{E}+04$ & $2.31 \mathrm{E}+01$ & Yes \\
\hline $\mathrm{Se}-79$ & $8.38 \mathrm{E}-03$ & $2.66 \mathrm{E}+03$ & $2.23 \mathrm{E}+01$ & Yes \\
\hline Sn-126 & $1.50 \mathrm{E}-04$ & $1.11 \mathrm{E}+05$ & $1.66 \mathrm{E}+01$ & Yes \\
\hline Ba-133 & $1.90 \mathrm{E}-03$ & $8.14 \mathrm{E}+03$ & $1.55 \mathrm{E}+01$ & Yes \\
\hline Re-187 & $8.94 \mathrm{E}-01$ & $1.63 \mathrm{E}+01$ & $1.46 \mathrm{E}+01$ & Yes \\
\hline $\mathrm{Pu}-242$ & $2.99 \mathrm{E}-04$ & $3.33 \mathrm{E}+04$ & $9.94 \mathrm{E}+00$ & Yes \\
\hline Hf- 182 & $1.08 \mathrm{E}-04$ & $8.51 \mathrm{E}+04$ & $9.18 \mathrm{E}+00$ & Yes \\
\hline $\mathrm{U}-233$ & $1.19 \mathrm{E}-04$ & $5.55 \mathrm{E}+04$ & $6.59 \mathrm{E}+00$ & Yes \\
\hline $\mathrm{Pa}-231$ & 8.77E-06 & $6.29 \mathrm{E}+05$ & $5.52 \mathrm{E}+00$ & Yes \\
\hline U-236 & $1.23 \mathrm{E}-04$ & $1.74 \mathrm{E}+04$ & $2.13 \mathrm{E}+00$ & Yes \\
\hline Ag-108m & $2.80 \mathrm{E}-05$ & $5.92 \mathrm{E}+04$ & $1.66 \mathrm{E}+00$ & Yes \\
\hline Th-228 & $2.98 \mathrm{E}-04$ & $2.63 \mathrm{E}+03$ & 7.83E-01 & Yes \\
\hline $\mathrm{Rh}-102$ & $1.16 \mathrm{E}-04$ & $6.66 \mathrm{E}+03$ & $7.75 \mathrm{E}-01$ & Yes \\
\hline Ac-227 & $1.77 \mathrm{E}-06$ & $2.41 \mathrm{E}+05$ & $4.26 \mathrm{E}-01$ & Yes \\
\hline Ir-192m & $9.26 \mathrm{E}-06$ & $4.07 \mathrm{E}+04$ & $3.77 \mathrm{E}-01$ & No \\
\hline Pt-193 & $8.74 \mathrm{E}-04$ & $2.92 \mathrm{E}+02$ & $2.56 \mathrm{E}-01$ & No \\
\hline Th-232 & $2.80 \mathrm{E}-07$ & $3.66 \mathrm{E}+05$ & $1.02 \mathrm{E}-01$ & No \\
\hline $\mathrm{Cm}-245$ & $1.36 \mathrm{E}-06$ & $6.29 \mathrm{E}+04$ & 8.54E-02 & No \\
\hline $\mathrm{Si}-32$ & $6.68 \mathrm{E}-07$ & $5.92 \mathrm{E}+04$ & 3.95E-02 & No \\
\hline Bi- $210 \mathrm{~m}$ & $8.55 \mathrm{E}-07$ & $4.07 \mathrm{E}+04$ & $3.48 \mathrm{E}-02$ & No \\
\hline $\mathrm{Pd}-107$ & $3.07 \mathrm{E}-04$ & $1.04 \mathrm{E}+02$ & $3.18 \mathrm{E}-02$ & No \\
\hline $\mathrm{Be}-10$ & $1.53 \mathrm{E}-04$ & $2.07 \mathrm{E}+02$ & $3.17 \mathrm{E}-02$ & No \\
\hline $\mathrm{Cm}-246$ & $1.03 \mathrm{E}-06$ & $3.00 \mathrm{E}+04$ & $3.10 \mathrm{E}-02$ & No \\
\hline Ra-228 & $2.60 \mathrm{E}-07$ & $1.11 \mathrm{E}+05$ & $2.88 \mathrm{E}-02$ & No \\
\hline Th-230 & $5.30 \mathrm{E}-08$ & $1.59 \mathrm{E}+05$ & $8.43 \mathrm{E}-03$ & No \\
\hline Th-229 & $5.63 \mathrm{E}-08$ & $1.18 \mathrm{E}+05$ & $6.66 \mathrm{E}-03$ & No \\
\hline $\mathrm{Rb}-87$ & $1.03 \mathrm{E}-06$ & $4.44 \mathrm{E}+03$ & 4.59E-03 & No \\
\hline $\mathrm{Pu}-236$ & $5.92 \mathrm{E}-07$ & $5.55 \mathrm{E}+03$ & $3.29 \mathrm{E}-03$ & No \\
\hline Ho- $166 \mathrm{~m}$ & $5.10 \mathrm{E}-08$ & $5.92 \mathrm{E}+04$ & $3.02 \mathrm{E}-03$ & No \\
\hline La-137 & $1.96 \mathrm{E}-06$ & $9.62 \mathrm{E}+02$ & $1.89 \mathrm{E}-03$ & No \\
\hline Pm-146 & $6.77 \mathrm{E}-08$ & $7.77 \mathrm{E}+03$ & $5.26 \mathrm{E}-04$ & No \\
\hline Lu-176 & $1.45 \mathrm{E}-08$ & $3.18 \mathrm{E}+04$ & 4.61E-04 & No \\
\hline
\end{tabular}


Table 10. (continued).

\begin{tabular}{lcccc}
\hline Radionuclide & $\begin{array}{c}\text { Inventory } \\
(\mathrm{Ci})\end{array}$ & $\begin{array}{c}\text { NCRP Screening Factor } \\
(\mathrm{mrem} / \mathrm{Ci})\end{array}$ & $\begin{array}{c}\text { NCRP Screening Dose } \\
(\text { mrem/year })\end{array}$ & Retained \\
\hline Tm-171 & $2.74 \mathrm{E}-07$ & $3.70 \mathrm{E}+02$ & $1.01 \mathrm{E}-04$ & No \\
Pb-205 & $8.23 \mathrm{E}-07$ & $6.66 \mathrm{E}+01$ & $5.48 \mathrm{E}-05$ & No \\
Ra-226 & $5.22 \mathrm{E}-11$ & $2.96 \mathrm{E}+05$ & $1.55 \mathrm{E}-05$ & No \\
Os-194 & $3.58 \mathrm{E}-09$ & $2.00 \mathrm{E}+03$ & $7.14 \mathrm{E}-06$ & No \\
Te-123 & $2.66 \mathrm{E}-09$ & $1.26 \mathrm{E}+03$ & $3.34 \mathrm{E}-06$ & No \\
Cf-250 & $1.46 \mathrm{E}-10$ & $1.18 \mathrm{E}+04$ & $1.73 \mathrm{E}-06$ & No \\
Sm-147 & $4.11 \mathrm{E}-10$ & $3.70 \mathrm{E}+03$ & $1.52 \mathrm{E}-06$ & No \\
Cf-249 & $5.66 \mathrm{E}-12$ & $5.55 \mathrm{E}+04$ & $3.14 \mathrm{E}-07$ & No \\
Pm-145 & $1.62 \mathrm{E}-10$ & $7.40 \mathrm{E}+02$ & $1.20 \mathrm{E}-07$ & No \\
Np-235 & $2.28 \mathrm{E}-09$ & $2.41 \mathrm{E}+01$ & $5.48 \mathrm{E}-08$ & No \\
Cm-247 & $1.89 \mathrm{E}-13$ & $5.55 \mathrm{E}+04$ & $1.05 \mathrm{E}-08$ & No \\
Cf-251 & $1.26 \mathrm{E}-13$ & $4.81 \mathrm{E}+04$ & $6.05 \mathrm{E}-09$ & No \\
In-115 & $4.91 \mathrm{E}-13$ & $2.96 \mathrm{E}+03$ & $1.45 \mathrm{E}-09$ & No \\
Tl-204 & $2.19 \mathrm{E}-22$ & $4.07 \mathrm{E}+02$ & $8.92 \mathrm{E}-20$ & No \\
Ru-106 & $3.11 \mathrm{E}+03$ & $0.00 \mathrm{E}+00$ & $0.00 \mathrm{E}+00$ & No \\
\hline
\end{tabular}

\subsection{Phase III Results}

Phase III accounts for advection and radioactive chain decay and ingrowth while in the vadose zone and for simple dilution in the aquifer. These results are site-specific and are based on application of the model discussed in Section 4.3 and the model parameterization presented in Section 5. In this step, calculated maximum groundwater screening concentrations are compared to the MCL for each radionuclide. Results for Sites 5 and 34 are shown in Table 11. This table indicates that 6 of the 56 radionuclides were retained for Phase IV analysis. These radionuclides are C-14, H-3, I-129, Ni-59, Tc-99 and U-238.

Table 11. Phase III screening results based on site-specific transport.

\begin{tabular}{lccccc}
\hline & & Kd & $\begin{array}{c}\text { ATR Complex (Site 5) } \\
\text { Groundwater } \\
\text { Screening } \\
\text { Concentration } \\
(\mathrm{pCi} / \mathrm{L})^{\mathrm{a}}\end{array}$ & $\begin{array}{c}\text { INTEC (Site 34) } \\
\text { Groundwater } \\
\text { Screening } \\
\text { Concentration } \\
(\mathrm{pCi} / \mathrm{L})^{\mathrm{a}}\end{array}$ & $\begin{array}{c}\text { Federal } \\
\text { Maximum } \\
\text { Contaminant } \\
\text { Level } \\
(\mathrm{pCi} / \mathrm{L})\end{array}$ \\
\hline Ac-227 & 450 & Jenkins (2001) & 0 & 0 & 15 \\
Ag-108m & 90 & DOE-ID (1994) & 0 & 0 & $627^{\mathrm{b}}$ \\
Am-241 & 2 & DOE-ID (2006a) & 0.02 & 0.02 & 15 \\
Am-242m & 340 & DOE-ID (1994) & 0 & 0 & 15 \\
Am-243 & 340 & DOE-ID (1994) & $4.0 \mathrm{E}-08$ & $4.4 \mathrm{E}-07$ & 15 \\
Ba-133 & 50 & DOE-ID (1994) & 0 & 0 & $967^{\mathrm{b}}$ \\
$\mathbf{C}-14$ & 0 & DOE-ID (1994) & $\mathbf{1 . 6 E}+\mathbf{0 6}$ & $\mathbf{1 . 7 E}+\mathbf{0 6}$ & $\mathbf{2 0 0 0}$ \\
\hline
\end{tabular}


Table 11. (continued).

\begin{tabular}{|c|c|c|c|c|c|}
\hline Radionuclide & $\begin{array}{c}\mathrm{Kd} \\
(\mathrm{mL} / \mathrm{g})\end{array}$ & $\begin{array}{c}\text { Kd } \\
\text { Reference }\end{array}$ & $\begin{array}{c}\text { ATR Complex (Site 5) } \\
\text { Groundwater } \\
\text { Screening } \\
\text { Concentration } \\
(\mathrm{pCi} / \mathrm{L})^{\mathrm{a}} \\
\end{array}$ & $\begin{array}{l}\text { INTEC (Site 34) } \\
\text { Groundwater } \\
\text { Screening } \\
\text { Concentration } \\
(\mathrm{pCi} / \mathrm{L})^{\mathrm{a}} \\
\end{array}$ & $\begin{array}{c}\text { Federal } \\
\text { Maximum } \\
\text { Contaminant } \\
\text { Level } \\
(\mathrm{pCi} / \mathrm{L}) \\
\end{array}$ \\
\hline $\mathrm{Ca}-41$ & 5 & DOE-ID (1994) & 0.62 & 0.62 & $7657^{\mathrm{b}}$ \\
\hline Cd-109 & 6 & DOE-ID (1994) & 0 & 0 & 600 \\
\hline Cd-113m & 6 & DOE-ID (1994) & 0 & 0 & $60^{\mathrm{b}}$ \\
\hline $\mathrm{Cl}-36$ & 0 & Jenkins (2001) & 618 & 619 & 700 \\
\hline $\mathrm{Cm}-243$ & 4000 & Jenkins (2001) & 0 & 0 & 15 \\
\hline $\mathrm{Cm}-244$ & 4000 & Jenkins (2001) & 0 & 0 & 15 \\
\hline Co-60 & 10 & DOE-ID (1994) & 0 & 0 & 100 \\
\hline Cs-134 & 50 & DOE-ID (2006a) & 0 & 0 & 80 \\
\hline Cs-135 & 50 & DOE-ID (2006a) & 0.07 & 0.07 & 900 \\
\hline Cs-137 & 50 & DOE-ID (2006a) & 0 & 0 & 200 \\
\hline Eu-152 & 340 & Jenkins (2001) & 0 & 0 & 200 \\
\hline Eu-154 & 340 & Jenkins (2001) & 0 & 0 & 200 \\
\hline Eu-155 & 340 & Jenkins (2001) & 0 & 0 & 600 \\
\hline Fe-55 & 220 & DOE-ID (1994) & 0 & 0 & 2000 \\
\hline H-3 & 0 & DOE-ID (1994) & $2.7 E+05$ & $6.1 \mathrm{E}+06$ & 20000 \\
\hline Hf-182 & 450 & Jenkins (2001) & $5.5 \mathrm{E}-05$ & $5.5 \mathrm{E}-05$ & $490^{\mathrm{b}}$ \\
\hline I-129 & 0 & DOE-ID (1994) & 537 & 537 & 1 \\
\hline $\mathrm{K}-40$ & 15 & DOE-ID (1994) & 0.02 & 0.02 & $240^{\mathrm{b}}$ \\
\hline Mo-93 & 10 & Jenkins (2001) & 366 & 429 & $469^{\mathrm{b}}$ \\
\hline Nb-93m & 100 & Jenkins (2001) & 0 & 0 & 1000 \\
\hline $\mathrm{Nb}-94$ & 100 & Jenkins (2001) & 91 & 117 & $853^{\mathrm{b}}$ \\
\hline Ni-59 & 100 & DOE-ID (1994) & 5735 & 6151 & 300 \\
\hline $\mathrm{Ni}-63$ & 100 & DOE-ID (1994) & 0 & 0 & 50 \\
\hline Np-237 & 2 & DOE-ID (2006a) & 0.3 & 0.3 & 15 \\
\hline Pa-231 & 550 & Jenkins (2001) & $1.1 \mathrm{E}-07$ & 2.7E-07 & 15 \\
\hline Pm-147 & 240 & Jenkins (2001) & 0 & 0 & $5668^{\mathrm{b}}$ \\
\hline $\mathrm{Pu}-238^{\mathrm{e}}$ & 1.6 & DOE-ID (2006a) & 0.06 & 0.06 & $1.9 \mathrm{E}+05^{\mathrm{c}}$ \\
\hline Pu-239 & 22 & Jenkins (2001) & 3.6 & 3.7 & 15 \\
\hline $\mathrm{Pu}-240$ & 22 & Jenkins (2001) & 1.0 & 1.2 & 15 \\
\hline $\mathrm{Pu}-241^{\mathrm{d}}$ & 2 & DOE-ID (2006a) & 0.02 & 0.02 & 15 \\
\hline $\mathrm{Pu}-242$ & 22 & Jenkins (2001) & 0.003 & 0.003 & 15 \\
\hline Re-187 & 10 & Jenkins (2001) & 21 & 21 & 9000 \\
\hline Rh-102 & 52 & Jenkins (2001) & 0 & 0 & $573^{\mathrm{b}}$ \\
\hline
\end{tabular}


Table 11. (continued).

\begin{tabular}{lccccc}
\hline Kd & Kd & $\begin{array}{c}\text { ATR Complex (Site 5) } \\
\text { Groundwater } \\
\text { Screening } \\
\text { Concentration } \\
(\mathrm{pCi} / \mathrm{L})^{\mathrm{a}}\end{array}$ & $\begin{array}{c}\text { INTEC (Site 34) } \\
\text { Groundwater } \\
\text { Screening } \\
\text { Concentration } \\
(\mathrm{pCi} / \mathrm{L})^{\mathrm{a}}\end{array}$ & $\begin{array}{c}\text { Federal } \\
\text { Maximum } \\
\text { Contaminant } \\
\text { Level } \\
(\mathrm{pCi} / \mathrm{L})\end{array}$ \\
\hline Sb-125 & 50 & DOE-ID (1994) & 0 & 0 & 300 \\
Se-79 & 4 & DOE-ID (1994) & 0.5 & 0.5 & $512^{\mathrm{b}}$ \\
Sm-151 & 240 & Jenkins (2001) & 0 & 0 & 1000 \\
Sn-121m & 130 & Jenkins (2001) & 0 & 0 & $6504^{\mathrm{b}}$ \\
Sn-126 & 130 & Jenkins (2001) & $2.0 \mathrm{E}-04$ & $2.2 \mathrm{E}-04$ & $310^{\mathrm{b}}$ \\
Sr-90 & 24 & DOE-ID (1994) & 0 & 0 & 8 \\
Ta-180 & 220 & Jenkins (2001) & 0.7 & 0.7 & $1757^{\mathrm{b}}$ \\
Tc-99 & 0 & DOE-ID (2006a) & $\mathbf{6 . 7 E + 0 4}$ & $\mathbf{6 . 7 E + 0 4}$ & $\mathbf{9 0 0}$ \\
Th-228 & 100 & DOE-ID (1994) & 0 & 0 & 15 \\
U-232 & 1.6 & DOE-ID (2006a) & $2.5 \mathrm{E}-04$ & $0.3 \mathrm{E}-03$ & $6.7 \mathrm{E}+08$ \\
U-233 & 1.6 & DOE-ID (2006a) & 0.02 & 0.2 & $2.9 \mathrm{E}+05$ \\
U-234 & 1.6 & DOE-ID (2006a) & 0.2 & 0.7 & $1.9 \mathrm{E}+05^{\mathrm{c}}$ \\
U-235 & 1.6 & DOE-ID (2006a) & 0.7 & 0.0 & 58 \\
U-236 & 1.6 & DOE-ID (2006a) & 0.0 & $\mathbf{2 2 5 8}$ & 1952 \\
U-238 & 1.6 & DOE-ID (2006a) & $\mathbf{2 2 5 8}$ & 15 & $\mathbf{1 0}^{\mathrm{c}}$ \\
Zr-93 & 600 & DOE-ID (1994) & 14 & & 2000 \\
\hline a & & & 0.0 & \\
\hline
\end{tabular}

a. Groundwater screening concentrations less than $1 \mathrm{E}-20$ are listed as zero.

b. MCL does not exist; calculated MCL as outlined in Section 2.1.

c. MCL for U-234 and U-238 converted from $30 \mathrm{ug} / \mathrm{L}$ mass concentration to equivalent activity concentration (in pCi/L).

d. Am-241 and Pu-241 modeled as progeny $\mathrm{Np}-237$

e. $\mathrm{Pu}-238$ modeled as progeny $\mathrm{U}-234$

NOTE: Bold shaded text indicates groundwater screening concentration greater than MCL.

\subsection{Phase IV Results}

The Phase III screening results (Table 11) indicate six radionuclides have a predicted groundwater screening concentration greater than the respective MCL. The Phase IV results for these six radionuclides are shown in Table 12 and include concentrations for the progeny of U-238. For both Site 5 and Site 34, the Phase IV peak groundwater screening concentrations are less than the corresponding MCLs. I-129 and Tc-99 have the highest concentrations with respect to MCL. For all radionuclides, the concentrations for Site 5 are lower than Site 34 concentrations. The largest difference is for H-3 where the Site 5 concentration is approximately 19 times less than the Site 34 concentration. 
Table 12. Phase IV screening results based on site-specific transport.

\begin{tabular}{lccccc}
\hline & $\begin{array}{c}\text { Site } 5 \\
\text { Phase IV } \\
\text { Maximum } \\
\text { Screening } \\
\text { Concentration } \\
(\mathrm{pCi} / \mathrm{L})\end{array}$ & $\begin{array}{c}\text { Site 5 } \\
\text { Time of Maximum } \\
\text { Concentration } \\
\text { (Calendar Year) }\end{array}$ & $\begin{array}{c}\text { Site 34 } \\
\text { Phase IV } \\
\text { Maximum } \\
\text { Screening } \\
\text { Concentration } \\
(\mathrm{pCi} / \mathrm{L})\end{array}$ & $\begin{array}{c}\text { Site 34 } \\
\text { Time of } \\
\text { Maximum } \\
\text { Concentration } \\
\text { (Calendar Year) }\end{array}$ & $\begin{array}{c}\text { Federal Maximum } \\
\text { Contaminant } \\
\text { Level } \\
(\mathrm{pCi} / \mathrm{L})\end{array}$ \\
\hline C-14 & 0.89 & 16065 & 14 & 8215 & 2,000 \\
H-3 & $4.3 \mathrm{E}-05$ & 2215 & $7.7 \mathrm{E}-04$ & 2215 & 20,000 \\
$\mathrm{I}-129$ & 0.49 & 7815 & 0.91 & 4915 & 1 \\
Ni-59 & 6.6 & 296065 & 22 & 224065 & 300 \\
Tc-99 & 209 & 2815 & 409 & 2590 & 900 \\
U-238 & 0.32 & 316065 & 1.1 & 72690 & $10^{\mathrm{b}}$ \\
U-234 & 0.19 & 316065 & 0.29 & 252065 & $1.9 \mathrm{E}+05^{\mathrm{b}}$ \\
Th-230 & 0.030 & 316065 & 0.090 & 316065 & 15 \\
Ra-229 & 0.031 & 316065 & 0.091 & 316065 & 5 \\
Pb-210 & 0.030 & 316065 & 0.088 & 316065 & 2.12 \\
\hline
\end{tabular}

a. Radioactive progeny of U-238.

b. MCL for U-234 and U-238 converted from $30 \mathrm{ug} / \mathrm{L}$ mass concentration to equivalent activity concentration (in $\mathrm{pCi} / \mathrm{L}$ ).

\section{COMPOSITE IMPACTS}

Assessing the cumulative or composite impacts to groundwater requires consideration of other sources of contaminants that currently exist in the aquifer or will enter the aquifer in the future. Locations of the sources include upgradient contaminants that could migrate through the aquifer volume potentially impacted by the RH-LLW disposal facility, nearby sources that could overlap the impacted region, and those sources downgradient that might be impacted by the RH-LLW disposal facility. Because Site 34 and Site 5 are separated by approximately 1.5 miles, the near-field composite analysis is site dependent. However, over longer time and transport distance, potentially overlapping downgradient sources for both proposed sites are similar. The near-field analysis is provided for both sites separately, followed by a single far-field analysis.

\subsection{Near-Field Impacts}

Site 5 essentially is located downgradient of the ATR Complex (Figure 1). There are no predicted or existing contaminants of concern in the aquifer upgradient of the ATR Complex. There have been historical releases within the ATR Complex identified and partially remediated through CERCLA activities (Dames and Moore 1992, DOE-ID 1997a, DOE-ID 2003a). Numerical flow and transport codes were used to identify contaminants that could pose unacceptable groundwater impacts through time. Identified contaminants of concern included chromium, tritium, Sr-90, and cadmium. Peak concentrations for all of these are predicted to be below their respective MCLs by the year 2029. It is highly unlikely that radionuclides will be released from the proposed RH-LLW facility during the 50-year operational period or during the following 100-year institutional control period. The offset in time means that preexisting contaminants from the ATR Complex will not increase predicted concentrations from the proposed RH-LLW disposal facility above Phase IV results shown in Table 12. 
Site 34 is located southwest of INTEC (Figure 1). There are no predicted or existing contaminants of concern in the aquifer upgradient of INTEC. However, as a result of historical accidental releases at INTEC, non-CERCLA and CERCLA investigations have identified I-129, Tc-99, H-3, Sr-90, Np-237, and nitrate as contaminants of concern for groundwater. A record of decision was reached in 2007 for the INTEC tank farm soils and groundwater (DOE-ID 2007b) and a remedy was selected to ensure contaminants of concern would be below their respective MCLs by the year 2095. It is supported by other cleanup projects, including actions performed under the Operable Unit 3-13 record of decision. This remedy includes disposition of sodium-bearing waste, closure of the tank farm facility, and deactivation, decontamination, and decommissioning of the surrounding infrastructure. Combined, these actions will permanently close and remediate the tank farm in accordance with applicable environmental regulations and DOE orders. It is anticipated that the tank farm facility will be closed in 2012. Following closure, INTEC cleanup and waste management activities will continue to support the 1995 Settlement Agreement (DOE 1995), whose key objectives are to remove all spent nuclear fuel from Idaho by the year 2035 and to prepare waste stored at INL for removal from Idaho by the same date. Many of the waste management facilities and infrastructure around the tank farm facility will remain active until that mission is completed. Some of the key waste management facilities include the buried tanks north of CPP-604 (WM-100, WM-101, WM-102, WL-101, WL-102 and WL-133); several buildings/structures (CPP-604, CPP-605, CPP-659, CPP-756, and the main stack); and transfer piping and valve boxes located in the tank farm. The Operable Unit 3-14 remedy will allow continued use of this infrastructure while protecting human health and the environment. The tank farm facility is in an area of established industrial infrastructure. Following closure, this infrastructure will include grouted underground tanks, piping, and ancillary equipment. In addition, the Waste Calcining Facility (CPP-633) has been closed with waste left in place to the standards applicable to a Hazardous Waste Management Act/Resource Conservation and Recovery Act landfill. The end state of other nearby facilities, such as the New Waste Calcining Facility (CPP-659) and the Fuel Reprocessing Complex (CPP-601, CPP-602, and CPP-630) is unknown at this time, but may include some permanent barriers such as grout. As a result, the agencies agreed that residential use over these facilities, the associated underground utilities, and the grouted tanks is not a reasonably anticipated future use and that an industrial future land use is appropriate.

CERCLA waste from INTEC and other INL facilities are consolidated in ICDF, which is located on the southwest corner of INTEC (Figure 13). ICDF is an engineered disposal facility equipped with a liner, a leachate collection system, and will be covered with an engineered infiltration-reducing barrier. Radionuclide migration and resultant concentrations and doses were predicted by the performance assessment for ICDF (DOE-ID 2010). The total beta-gamma dose equivalent (calculated using federal MCL values based on a 4-mrem/year dose equivalent, assuming a 730-L/year ingestion rate, and data from the National Bureau of Standards Handbook 69) was predicted to be less than the allowable 4-mrem/year value within the first 1,000 years and was predicted to be $2.2 \mathrm{mrem} /$ year beyond year 3018 . The primary beta contributor was I-129.

\subsection{Far-Field Impacts}

Operable Unit 10-08 addressed the potential for commingling of contaminant plumes from primary INL facilities using a subregional scale, three-dimensional flow and transport model of the Snake River Plain Aquifer. Results were combined to obtain the isopleths for one-tenth the MCL for each contaminant. The following contaminants had simulated concentrations less than one-tenth the MCL in 2005: Np-237, Tc-99, chromium, methylene chloride, tetrachloroethene, and trichloroethene. 


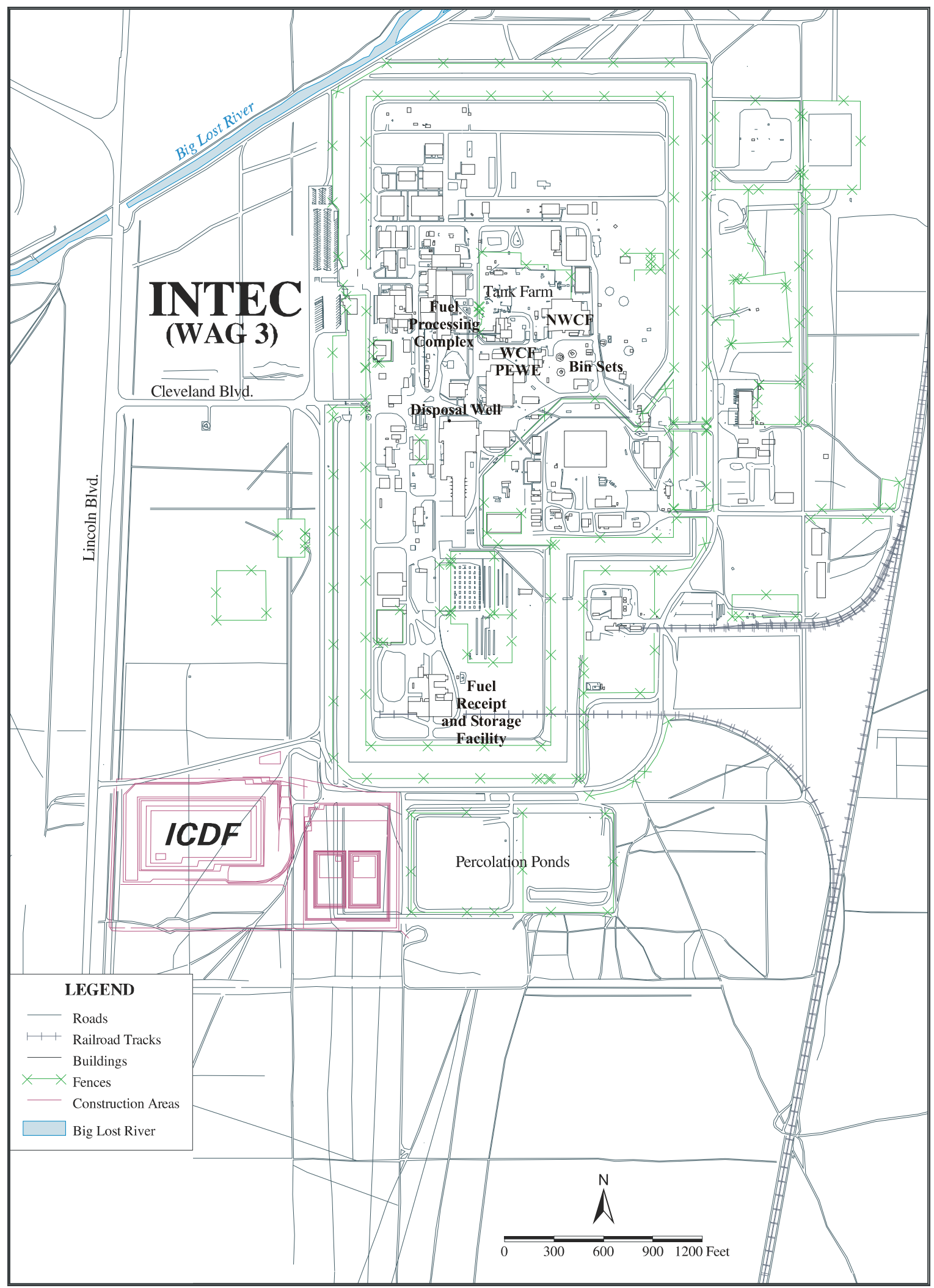

Figure 13. Location of the Idaho CERCLA Disposal Facility complex. 
For those contaminants that resulted in concentrations above one-tenth the MCL, individual facility isopleths were combined to determine if any portion of the plumes overlapped. Year 2005 was simulated because data using ultralow-level laboratory detection methods were available to compare to modeling results. Future plume overlap was simulated to the year 2095. The only strict overlap is the tritium (H-3) plumes in 2005 from the ATR Complex (Waste Area Group 2) and INTEC (Waste Area Group 3) sources and nitrate in 2005 for INTEC (Waste Area Group 3) and the Central Facility Area (Waste Area Group 4) sources. The model predicts no overlapping plumes in 2095.

The sum of the simulated individual facility plume concentrations for all beta-emitting radionuclides divided by their respective MCLs are superimposed on one contour plot for 2005 (Figure 14) and 2095 (Figure 15). The isopleth for one-tenth the MCL is shown in the figures to delineate areas of simulated commingled plumes. Plumes from the ATR Complex (Waste Area Group 2), INTEC (Waste Area Group 3), and RWMC (Waste Area Group 7) are all shown in Figures 14 and 15. The 2005 results were dominated by tritium (H-3) and the 2095 results were predominantly influenced by I- 129 .

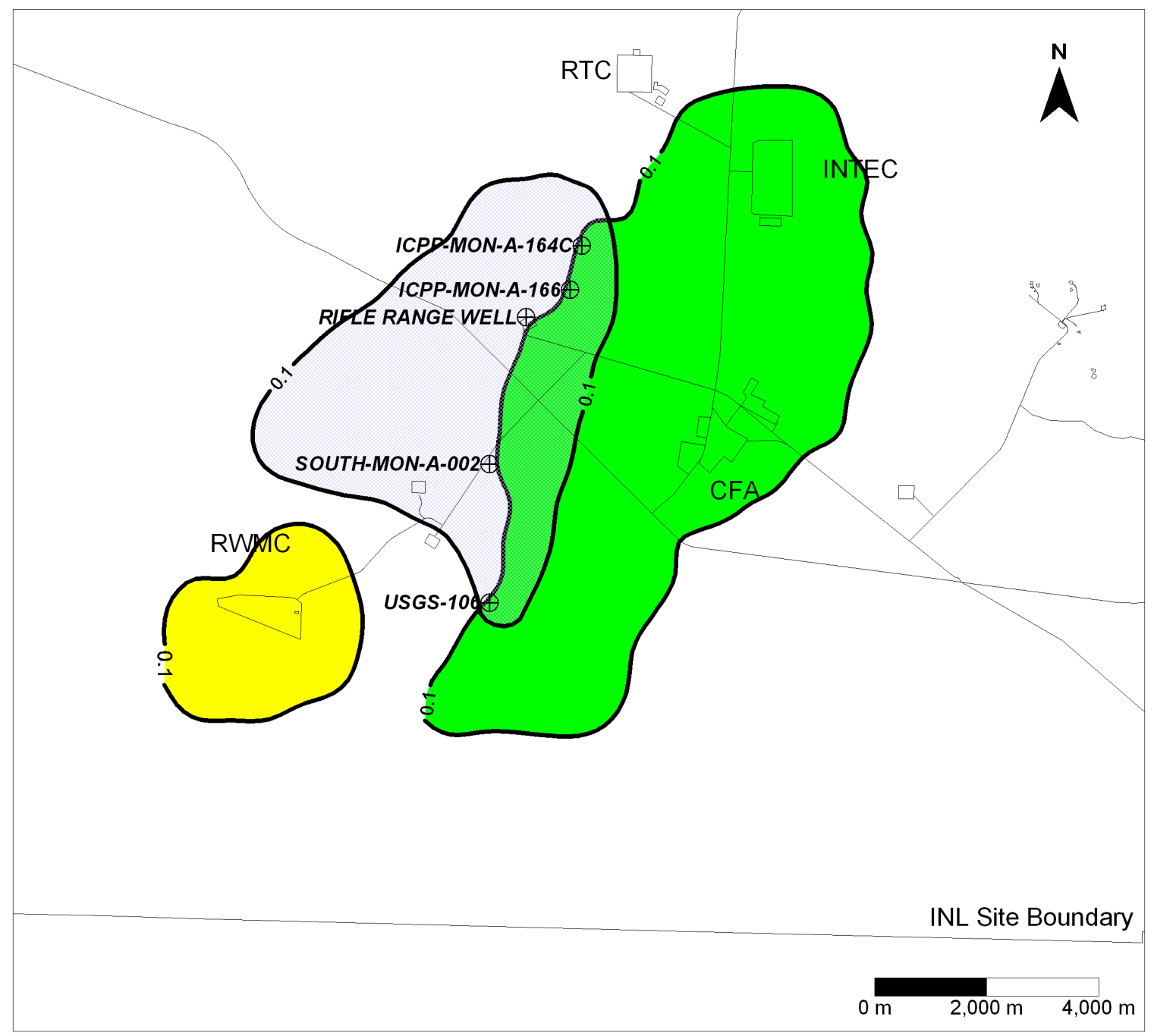

Figure 14. Sum of simulated beta-emitting radionuclide concentrations divided by respective drinking water limits for 2005. Note 1: light blue $=$ Advanced Test Reactor Complex; green $=$ Idaho Nuclear Technology and Engineering Center; yellow $=$ Radioactive Waste Management Complex. Note 2: Data from monitoring wells do not indicate commingling of contaminants. Figure is from DOE-ID 2008. 


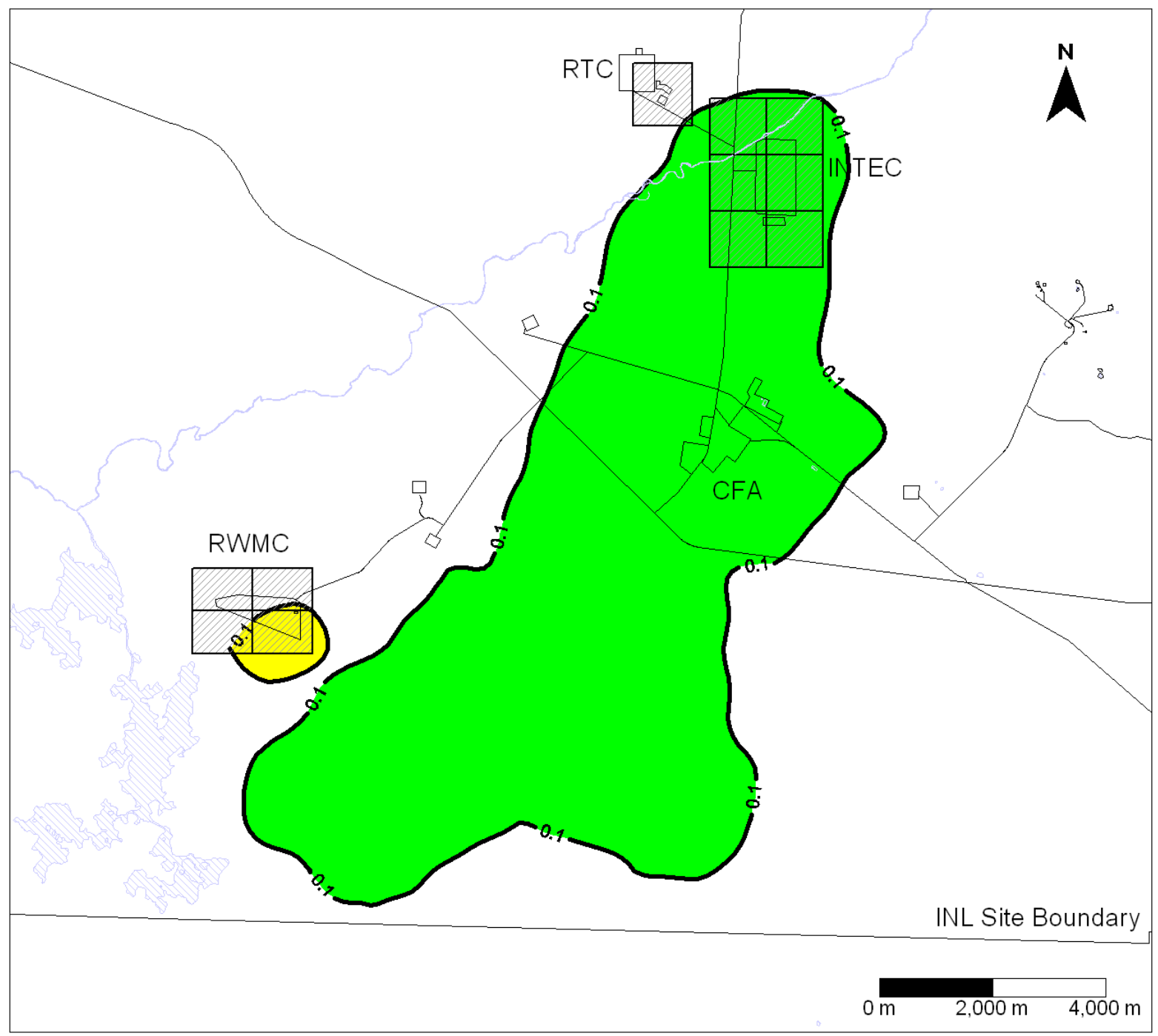

Figure 15. Sum of simulated beta-emitting radionuclide concentrations divided by respective drinking water limits for 2095. Note 1: light blue = Advanced Test Reactor Complex; green = Idaho Nuclear Technology and Engineering Center; yellow = Radioactive Waste Management Complex. Note 2: Data from monitoring wells do not indicate commingling of contaminants. Figure is from DOE-ID 2008.

In 2005, the model predicted that an area of commingling should occur between the Waste Area Group 2 plume and the Waste Area Group 3 plume. However, data from the four monitoring wells in this area show no evidence of commingling plumes between those facilities.

Commingling beyond the year 2095 was not evaluated for the CERCLA plumes because each individual facility is responsible for ensuring concentrations originating at each facility are below MCLs. However, radionuclides originating from ICDF are predicted to arrive in the aquifer after the year 3018 . The delayed arrival from ICDF will result in part because of the well-mixed soil-radionuclide waste form and, in part, because of the infiltration-reducing engineered cover. Radionuclide arrival in the aquifer from the proposed RH-LLW disposal facility also will be delayed in time, in part because of the cement-steel-sand vault system and because of the infiltration-reducing engineered cover. The timeline for arrival of radionuclides to the aquifer from the proposed RH-LLW disposal facility will be more likely to coincide with the arrival of radionuclides from ICDF for similar reasons. 


\subsection{Composite Impacts Summary}

For Site 5, it is unlikely that groundwater concentrations will exceed those predicted by the Phase IV screening analysis shown in Table 12. As shown in Figures 14 and 15, the potential for commingled plumes originating in the vicinity of the proposed Site 5 is highest near RWMC. The time period required for this to occur is well in exceedance of 1,000 years, based on the predicted arrival of I-129. The predicted concentrations at the facility boundary for I-129 is about half the MCL, which suggests that concentrations downgradient at RWMC will never exceed the MCL.

For Site 34, it is possible that groundwater concentrations downgradient of Site 34 could exceed those predicted by the Phase IV screening analysis. Commingled I-129 originating in the RH-LLW disposal facility and from ICDF could result in groundwater concentrations exceeding the MCL because the predicted peak I-129 concentration in Phase IV screening is about $90 \%$ of the I-129 MCL of $1 \mathrm{pCi} / \mathrm{L}$. As with Site 5, it is unlikely that additional impacts will be realized from contaminants at the Central Facilities Area or RWMC.

\section{SUMMARY}

The analysis presented was prepared to support the National Environmental Policy Act environmental assessment for the top two proposed sites for the RH-LLW disposal facility and an estimated 50-year inventory. Groundwater impacts have been analyzed using a four-step analysis approach. This assessment compared the predicted groundwater screening concentrations to the maximum contaminant levels. The results show that for all radionuclides, the maximum predicted screening concentrations (using successively less conservative approaches and models) were less than the maximum contaminant levels for both Site 5 and Site 34.

\section{REFERENCES}

40 CFR 141, "National Primary Drinking Water Regulations," Code of Federal Regulations, June 2010.

42 USC § 4321 et seq., "National Environmental Policy Act of 1969 (NEPA)," United States Code, January 1970.

Adler-Flitton, M. K., C. W. Bishop, M. E. Delwiche, and T. S. Yoder, 2004, Long Term Corrosion/Degradation Test Six Year Results, INEEL/EXT-04-02335, U.S. Department of Energy Idaho Operations Office.

Appelo, C. A. J. and A. Willemsen, 1987, "Geochemical Calculations and Observations on Salt Water Intrusions, I. A Combined Geochemical/Mixing Cell Model," Journal of Hydrology, 94, pp. 313-330.

Baes, C. F. III and R. D. Sharp, 1983, "A Proposal for Estimation of Soil Leaching and Leaching Constants for Use in Assessment Models," Journal of Environmental Quality, Vol. 12, No. 1, pp. 17-28.

Cecil, L. D., J. R. Pittman, T. M. Beasley, R. L. Michel, P. W. Kubik, P. Sharma, U. Fehn, and H. Gove, 1992, "Water Infiltration Rates in the Unsaturated Zone at the Idaho National Engineering Laboratory Estimated by Chlorine-36 and Tritium Profiles, and Neutron Logging," in Proceedings of the $7^{\text {th }}$ International Symposium on Water-Rock Interactions, WRI-7, Y. K. Kharaka and A. S. Meest, eds., Park City, Utah, July 13-18, 1992. 
Codell, R. B., K. T. Key, and G. Whelan, 1982, A Collection of Mathematical Models for Dispersion in Surface Water and Groundwater, NUREG-0868, U.S. Nuclear Regulatory Commission, June 1982.

Codell, R. B., K. T. Key, and G. Whelan, 1983, "Transport of Radionuclides in Groundwater," in Radiological Assessment, NUREG/CR-3332, J. E. Till and H. R. Meyer, eds., U.S. Nuclear Regulatory Commission, Washington, DC, 1983.

Dames and Moore, 1992, Remedial Investigation Report for the Test Reactor Area Perched Water System (Operable Unit 2-12), EGG-WM-10002, Revision 0, Idaho National Engineering and Environmental Laboratory, June 1992.

DOE, 1995, Settlement Agreement, U. S. Department of Energy, U.S. Department of the Navy, and the State of Idaho.

DOE-ID, 1994, Track 2 Sites: Guidance for Assessing Low Probability Hazard Sites at the INEL, DOE/ID-10389, U.S. Department of Energy Idaho Operations Office, January 1994.

DOE-ID, 1997a, Comprehensive Remedial Investigation/Feasibility Study for the Idaho Test Reactor Area Operable Unit 2-13 at the Idaho National Engineering and Environmental Laboratory, DOE/ID-10531, U.S. Department of Energy Idaho Operations Office.

DOE-ID, 1997b, Comprehensive Remedial Investigation/Feasibility Study for the Idaho Chemical Processing Plant Operable Unit 3-13 at the INEEL-Part A, DOE/ID-10534, U.S. Department of Energy Idaho Operations Office.

DOE-ID, 2003a, First Five-Year Review Report for the Test Reactor Area, Operable Unit 2-13, at the Idaho National Engineering and Environmental Laboratory, DOE/ID-11099, Rev. 0, U.S. Department of Energy Idaho Operations Office, September 2003.

DOE-ID, 2003b, Performance Assessment for the INEEL CERCLA Disposal Facility Landfill (Draft), DOE/ID-10978, Rev. 1, Draft A, U.S. Department of Energy Idaho Operations Office, March 2010 .

DOE-ID, 2003c, Phase I Monitoring Well and Tracer Study Report for Operable Unit 3-13, Group 4, Perched Water, DOE/ID-10967, U.S. Department of Energy Idaho Operations Office, June 2003.

DOE-ID, 2004, Spatial Variability of Sedimentary Interbed Properties Near the INTEC at the INEEL, Knobel, L. L., USGS Water Resources Investigation Report 03-4142, also as DOE/ID-22187, U.S. Department of Energy Idaho Operations Office, 2004.

DOE-ID, 2005, Waste Area Group 10, Operable Unit 10-08, Remedial Investigation/Feasibility Study Annual Status Report for Fiscal Year 2004, DOE/NE-ID-11198, U.S. Department of Energy Idaho Operations Office, March 2005.

DOE-ID, 2006a, Operable Unit 3-14 Tank Farm Soil and Groundwater Remedial Investigation/Baseline Risk Assessment, DOE/ID-11227, U.S. Department of Energy Idaho Operations Office, April 2006.

DOE-ID, 2006b, Remedial Investigation and Baseline Risk Assessment for Operable Unit 7-13/14, DOE/ID-11241, Rev. 0, U.S. Department of Energy Idaho Operations Office, May 2006. 
DOE-ID, 2007a, Performance Assessment for the RWMC Active Low-Level Waste Disposal Facility at the Idaho National Laboratory Site, DOE/NE-ID-11243, U.S. Department of Energy Idaho Operations Office, September 2007.

DOE-ID, 2007b, Record of Decision (ROD) for Tank Farm Soil and Idaho Nuclear Technology and Engineering Center (INTEC) Groundwater, Operable Unit (OU) 3-14, DOE/ID-11296, Rev. 0, U.S. Department of Energy Idaho Operations Office.

DOE-ID, 2008, Operable Unit 10-08 Sitewide Groundwater and Miscellaneous Sites Remedial Investigation/Baseline Risk Assessment (RI/BRA), DOE/ID-11332, U.S. Department of Energy Idaho Operations Office, April 2008.

DOE-ID, 2010, Performance Assessment for the Idaho CERCLA Disposal Facility (DRAFT), DOE/ID-10978, U.S. Department of Energy Idaho Operations Office.

DOE Order 435.1, “Radioactive Waste Management,” Change 1, U.S. Department of Energy, July 1999.

Doornbos, M. H, J. L. Mattick, D. L. McElroy, L. V. Street, C. S. Blackmore, and C. A. Dicke, 1991, Environmental Characterization Report for the Test Reactor Area, EGG-WM-9690, Rev. 0, Idaho National Engineering Laboratory, September 1991.

ECAR-851, 2010, "Estimate of the Radionuclide Content of Future Resins Generation at ATR from 2016 to 2065," Engineering Calculation and Analysis Report, Idaho National Laboratory, May 2010.

ECAR-854, 2010, "Estimate of the Radionuclide Content of Future Activated Metal Generation at ATR from 2016 to 2065," Engineering Calculation and Analysis Report, Idaho National Laboratory, January 2010.

ECAR-904, 2010, “A Methodology for Retrofitting Source-Terms to Previously Inadequately Characterized EBR-II Irradiated Reactor Hardware as Waste (Source Term and Volume Estimate for MFC Generated Remote Handled Low Level Waste from 2016 to 2065, Engineering Calculation and Analysis Report, Idaho National Laboratory, June 2010.

ECAR-967, 2010, "Source Term and Volume Estimate for MFC Generated Remote Handled Low Level Waste from 2016 to 2065," Engineering Calculation and Analysis Report, Idaho National Laboratory, June 2010.

EPA, 1999, Cancer Risk Coefficients for Environmental Exposure to Radionuclides"; Federal Guidance Report 13, EPA-402-R-99-001, U.S. Environmental Protection Agency, Office of Radiation and Indoor Air, 1999.

Harvego, L., J. Connolly, L. Peterson, B. Orr, and B. Starr, 2010, Siting Study for the Remote-Handled Low-Level Waste Disposal Facility, INL/EXT-07-12902, Idaho National Laboratory, January 2010.

Helm-Clark, C., S. Ansley, T. McLing, and T. Wood, 2005, Borehole and Well Middle-1823 and It's Relationship to the Stratigraphy of the South-Central Idaho National Laboratory, ICP/EXT-0500790, March 2005.

INL, 2010a, Conceptual Design Report for the Remote-Handled Low-Level Waste Disposal Facility, INL/EXT-07-12901, Revision 3, Idaho National Laboratory, June 2010. 
INL, 2010b, Evaluation of Sedimentary Structure Near the Advance Test Reactor Complex at the Idaho National Laboratory (DRAFT), INL/EXT-10-18762, Idaho National Laboratory.

INL, 2010c, Assessment of Geochemical Environment for the Proposed INL Remote-Handled Low-Level Waste Disposal Facility (DRAFT), INL/EXT-10-19385, Idaho National Laboratory.

Jenkins, T., 2001, U.S. Department of Energy Idaho Operations Office, letter, to Marty Doornbos, Idaho National Engineering and Environmental Laboratory, July 3, 2001, "Kd Values for INTEC Groundwater Modeling," EM-ER-01-115.

Kennedy, W. E. and D. L. Strenge, 1992, Residual Radioactive Contamination from Decommissioning, NUREG/CR-5512, U.S. Nuclear Regulatory Commission.

Levenspiel, O. and K. B. Bischoff, 1963, "Patterns of Flow in Chemical Process Vessels" in T. B. Drew, J. W. Hoopes, Jr., and T. Vermeulen Eds., Advances in Chemical Engineering, Vol. 4, Academic Press, New York, 95-198.

Martian, P., 1995, UNSAT-H Infiltration Model Calibration at the Subsurface Disposal Area, Idaho National Engineering Laboratory, INEL-95/0596, Idaho National Engineering Laboratory.

Martian, P. and S. O. Magnuson, 1994, A Simulation Study of Infiltration Into Surficial Sediments at the Subsurface Disposal Area, Idaho National Engineering Laboratory, EGG-WM-11250, Idaho National Engineering and Environmental Laboratory.

Mattson, E., M. Ankeny, S. Dwyer, N. Hampton, G. Matthern, B. Pace, A. Parsons, M. Plummer, S. Reese, and J. Waugh, 2004, Preliminary Design for an Engineered Surface Barrier at the Subsurface Disposal Area, ICP/EXT-04-00216, Idaho National Engineering and Environmental Laboratory, Idaho Completion Project.

NBS, 1963, Maximum Permissible Body Burdens and Maximum Permissible Concentrations of Radionuclides in Air or Water for Occupational Exposure, National Bureau of Standards Handbook 69, U.S. Department of Commerce, Amended August 1963.

NCRP, 1996, Screening Models for Releases of Radionuclides to Atmospheric, Surface Water, and Ground - Worksheets, NCRP Report No. 123 II (Vol. 2), National Council on Radiation Protection and Measurement.

NRF, 2010, Updated Long Range Radioactivity Waste Inventory Estimate for NRF RH-LLW, Letter Report NRF-WS-510 from J. W. Frazier to L. A. Harvego, Naval Reactors Facility, Waste and Shipping, Bechtel Marine Propulsion Corporation, Bettis Atomic Power Laboratory, July 7, 2010.

Nagata, P. K. and J. Banaee, 1996, Estimation of the Underground Corrosion Rates for Low-Carbon Steels; Types 304 and 316 Stainless Steels; and Inconel 600, 601, and 718 Alloys at the Radioactive Waste Management Complex, INEL-096/098, Idaho National Engineering Laboratory, July 1996.

Oztunali, O. I. and G. W. Roles, 1985, Update of Part 61 Impacts Analysis Methodology, NUREG/CR-4370, Vol. 1, U.S. Nuclear Regulatory Commission. 
Rood, A. S., 2003, GWSCREEN: A Semi-Analytical Model for Assessment of the Groundwater Pathway from Surface or Buried Contamination, Theory and User's Manual, Version 2.5, INEEL/EXT-98-00750, Idaho National Engineering and Environmental Laboratory, April 2003.

Rood, A. S., 2005, Mixing Cell Model: A One-Dimensional Numerical Model for Assessment of Water Flow and Contaminant Transport in the Unsaturated Zone, ICP/EXT-05-00748, Rev. 0, Idaho Completion Project, Idaho Falls, March 2005.

Scott, S. J. and D. M. Hetrick, 1994, The New SESOIL User's Guide, PUBL-SW-200-94, Science and Technology Management Inc., Brookfield, WI, distributed by the Radiation Safety Information Computational Center, Oak Ridge National Laboratory, Oak Ridge, Tennessee, 1994.

Shanahan, P. and D. R. F. Harleman, 1984, “Transport in Lake Water Quality Modeling," Journal of Environmental Engineering, 110(1), pp. 42-57.

Sheppard, M. I. and D. H. Thibault, 1990, "Default Soil Solid/Liquid Partition Coefficients, $\mathrm{K}_{\mathrm{d}} \mathrm{s}$, for Four Major Soil Types: A Compendium,” Health Physics, Vol. 59, No. 4, pp. 471-482.

van Genuchten, M. Th., 1980, "A Closed-form Equation for Predicting the Hydraulic Conductivity of Unsaturated Soils,” Soil Sci. Soc. Am J., 44, 892-898.

Van Ommen, H. C., 1985, “The Mixing Cell Concept Applied to Transport of Non-Reactive and Reactive Components in Soils and Groundwater," Journal of Hydrology, 78, pp. 201-213.

Whelan, G., J. P. McDonald, and C. Sato, 1996, Multimedia Environmental Pollutant Assessment System (MEPAS) Groundwater Pathway Formulations, PNNL-10907, Pacific Northwest National Laboratory, June 1996.

Wood, T. R., C. M. Helm-Clark, H. Huang, S. Magnuson, T. McLing, B. Orr, M. J. Rohe, M. A. Plummer, R. Podgorney, E. Whitmore, and M. S. Roddy, 2007, Development Report on the Idaho National Laboratory Sitewide Three-Dimensional Aquifer Model, INL/EXT-13337, U.S. Department of Energy Idaho Operations Office, September 2007.

Yu, C., A. J. Zielen, J. J. Cheng, D. J. LePoire, E. Gnanapragasam, S. Kamboj, J. Arnish, A. Wallo III, W. A. Williams, and H. Peterson, 2001, User's Manual for RESRAD Version 6, ANL/EAD-4, Environmental Assessment Division, Argonne National Laboratory, July 2001.

Zvirin, T., and R. Shinnar, 1976, "Interpretation of Internal Tracer Experiments and Local Sojourn Time Distributions," International Journal of Multiphase Flow, 2, pp. 495-520. 